\title{
Against Dicta: A Legal Method for Rescuing Fair Use From the Right of First Publication
}

\author{
Kate O’Neill†
}

\section{TABle of Contents}

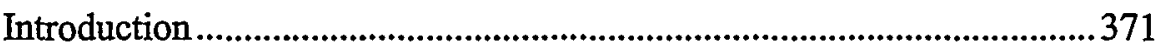

I. The Current Doctrine of "Fair Use" ..................................................379

A. Statutory Framework: Copyright Acts of 1909 \& 1976...............379

B. The Debate Over Unpublished Materials and the Right of First Publication .................................................. 381

C. A Façade of Doctrinal Coherence:

Campbell v. Acuff-Rose Music, Inc. ..........................................385

D. Recommendations for Reform: Injecting Determinacy into

Fair Use Doctrine.

1. Rejecting the Presumption Against

Fair Use of Unpublished Materials.......................................387

2. Reaffirming Statutory Copyright to

"Works of Authorship".......................................................390

3. Reconfiguring the Statutory Factors........................................391

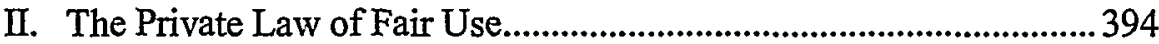

A. Risk Allocation: Burden on the Writers.....................................397

B. Risk Aversion: Financial Incentives of the Publishers.................400

C. Market Failure of Private Fair Use Law........................................404

III. The Rhetoric of Section 107, Harper \& Row, and Salinger .............. 407

A. The Incoherence of Fair Use Law: Section 107 of the 1976

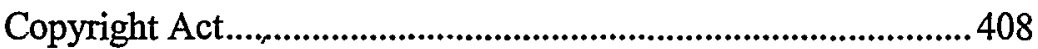

B. The Incoherence of Fair Use Law: Judicial Approaches ............411

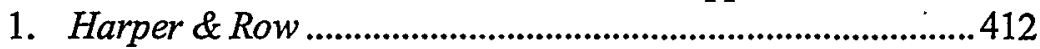

a. Facts of the Case .................................................................413

Copyright $\odot 2001$ California Law Review, Inc. Califomia Law Review Incorporated (CLR) is a Califormia nonprofit corporation. CLR and the authors are solely responsible for the content of their publications.

$\dagger$ Assistant Professor, Scliool of Law, University of Washington; J.D. 1980, Columbia University; A.B. 1975, Stanford University. I would like to thank the University of Washington Law School Foundation and Dean Roland L. Hjorth for their support. 
b. Holding of the Court .......................................................414

c. Structural and Syntactical Analysis ................................419

i. Part II .......................................................................419

ii. Parts III \& IV ..........................................................424

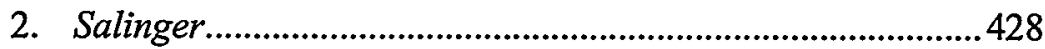

a. Facts of the Case ...............................................................429

b. Holding of the Court ..........................................................430

c. Structural and Syntactical Analysis ..................................431

IV. The Aftermath: Has Fair Use Been "Rescued" After All? ................ 436

A. The More Things Change, the More They Stay the

Same: Sundeman v. Seajay Society ............................................40

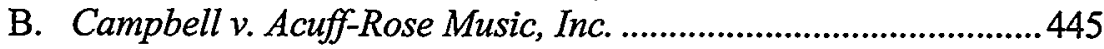

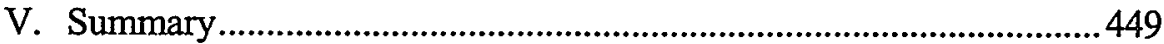

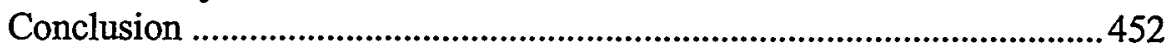

Appendix: Selections froin Simon \& Schuster Contract...........................455 


\title{
Against Dicta: A Legal Method for Rescuing Fair Use From the Right of First Publication
}

\author{
Kate O’Neill
}

Beginning with the 1985 Supreme Court decision in Harper \& Row Publishers, Inc. v. Nation Enterprises, the judiciary has pit the interests of the press, biographers, historians, and their readers against the interests of diarists, letter writers, and manuscript drafters in controlling access to unpublished papers. The Article summarizes the judicial decisions, copyright legislation, scholarly criticism, and trade publishing practices during the succeeding fifieen years. The ftrst thesis is that "loaded" judicial rhetoric used to bolster a few hard judgments, and subsequent courts' reliance on that dicta, has subjected to the property-rights regime of copyright nearly every bit of expression written by an individual, without regard to the individual's interest in the expression or its value to the public. The second thesis is that the judicial rhetoric has inspired and now sustains a private law of publishing that essentially bars the unlicensed quotation of any unpublished writings. This private law disserves readers' interests in accuracy and reasoned debate about texts, events, and characters. The third thesis is that the courts' inability to acknowledge privacy-like interests within the traditional utilitarian rhetoric of American copyright law has contributed to the "loaded" rhetoric. Together, these three theses suggest that judicial rhetoric deserves greater attention because it can generate "doctrine" as enduring as any "holding."

\section{INTRODUCTION}

The United States Copyright Act extends certain exclusive rights to the creators of "original works of authorship." Section 107 of that Act subjects those rights to limited invasion under a doctrine known as "fair use."2 That construct reflects a long-standing tension between "authors" rights $^{93}$ and the public interest in access to works. ${ }^{4}$

1. 17 U.S.C. $§ 102(a)$ (1994).

2. Id. $\S 107$.

3. The phrase "authors' rights" refers to a collection of rights assigned to the initial creator of a work of original expression. Defining the term more precisely implicates much of the analysis in the Article. A long-standing scholarly debate concerns whether the United States version of "authors' rights" includes only commercial interests or extends to personality interests, such as reputation. The 
The popular press regularly reports high profile struggles to control the use of literary expression, particularly the unpublished writings of famous people. From a dispute about publication of Anne Frank's previously unpublished writings, to the efforts of Thurgood Marshall's widow to block the use of his papers, to the irony of Joyce Maynard's "tell all" memoir of her affair with reclusive J. D. Salinger and Salinger's own daughter's memoir of life with her father, to the surprise over Ted Hughes's intimate poems about his famous spouse, Sylvia Plath, these reports reveal a boundary dispute over literary expression between the advocates of public access to information and the advocates of personal autonomy and privacy.

For a published work, the boundary is like a beach. During creation, the writer's personality engulfs the work, as water covers the sand; as the tide recedes, it leaves the beach, high and dry, the work formed and distinct from the writer. But for some unpublished writings, the boundary is murky, hidden like the lime between sea and land in a salt marsh. This Article wades into that murky boundary of fair use to examine whether the contemporary legal doctrine properly mediates the boundary dispute between, on one hand, the public interest $\mathrm{m}$ accessing information and original expression and, on the other, the individual writer's interest im revealing her writing as and when she chooses. The Article concludes that the courts have not clarified the boundary, but have sacrificed sound common law reasoning to mampulative rhetoric that has, perhaps unintentionally, resulted in over-protection of imprecise "authors' rights" to the detriment of the reading public.

Three examples illustrate the practical difficulty of defining this murky boundary either in industry practice or as a matter of law. In the first instance, a leading New York publisher of a literary biography recently refused to publish two words ("Jew" with "horns") of an unpublished letter stored in a public archive that Eudora Welty had written to Katherine Anne

latter interests are associated with natural law and civil law concepts of "moral rights." Useful discussions of these competing theories may be found in Jane C. Ginsburg, Authors and Users in Copyright, 45 J. CoPYRIGHT Soc'y 1 (1997); Justin Hughes, The Personality Interest of Artists and Inventors in Intellectual Property, 16 CARDozo ARTs \& ENT. L.J. 81 (1998); Alfred C. Yen, Restoring the Natural Law: Copyright as Labor and Possession, 51 OHI Sr. L.J. 517 (1990); Note, An Author's Artistic Reputation Under the Copyright Act of 1976, 92 HARv. L. REv. 1490 (1979).

As used in this Article, the phrase "authors' rights," whether broadly or narrowly construed, is best understood in contrast to users' rights to copy the work. Even this simple dichotony presents some potential confusion since this Article is principally concerned with users who are themselves writers. Such user-writers, who incorporate older works into new works, may themselves enjoy "authors' rights" in the new work.

4. These are traditional constructs of copyright doctrine. The Article does not address nontraditional economic or post-modern analyses because of its focus on the rhetorical strategies the courts employ, and these strategies, to date, reflect the traditional constructs. 
Porter. ${ }^{5}$ The biographer wanted to illustrate that Welty shared attitudes typical of her time and place and argued to the publisher that a fuller quotation would reveal that Welty's attitudes were less offensive than these two words might suggest, but the publisher would not be moved. In the second example, Robert Lowell asked Elizabeth Bishop some years ago for permission to sell to an archive letters that she had sent him. She reluctantly agreed in return for half of the proceeds. ${ }^{6}$ Both Lowell and Bishop are now dead, and under current trade publishing practice, a critic or biographer would need the estate executor's permission to quote at all. In the third example, in contrast, the Fourth Circuit recently permitted very substantial copying of an unpublished manuscript without permission. ${ }^{8}$

Commouly described as an "equitable rule of reason," the fair use doctrine allows certain limited uses of copyrighted expression without the permission of the writer or other copyright holder. Congress imcorporated this common law exception to copyright's exclusivity in the Copyright Act of 1976 ostensibly without change and without legislative intent to constram future judicial development of the doctrine. Nonetheless, the codification did impair doctrinal development, not by determining particular judgments, but by inspiring unreasonable and misleading opinions. The statute neither defines "fair use," nor directs a particular analysis; instead, it offers four nonexclusive factors for consideration. ${ }^{9}$ Despite the discretion afforded the courts, the opinions consistently purport to base judgments on analysis of the non-exclusive factors. Although the factors may be inconsistent, redundant, or irrelevant in particular cases, the courts unnecessarily defer to the statutory scheme and suppress other possibly more relevant criteria. The result is tortured logic and rampant dicta. While some scholars, dissenters, and even Justice Souter ${ }^{10}$ have criticized certain courts for failing to interpret precedent intelligently, recent opinions persist in relying on key phrases im Supreme Court opinions to support judgments on quite different facts. Although the courts repeat that fair use disputes cannot be resolved with "bright-line rules" but

5. Letter from Eudora Welty, novelist and short-story writer, to Katherine Anne Porter, novelist and short-story writer (Summer 1942) (on file with author) (The date is uncertain. A handwritten notation reads "undated/probably summer.").

6. Letter from Robert Lowell, poet, to Elizabeth Bishop, poet (Mar. 19, 1973) (on file with author); letter from Elizabeth Bishop to Robert Lowell (Apr. 29, 1973) (on file with author). This transaction is mentioned im Paul Mariani, The Lost PurTtan 418 (1994).

7. See infra note 98 for two examples of trade publishing guidelines barring unlicensed use of letters and other unpublished materials.

8. Sundeman v. Seajay Soc'y, Inc., 142 F.3d 194, 202-03 (4th Cir. 1998).

9. The fair use factors, in brief, are: (1) the nature of the use; (2) the nature of the original copyrighted work; (3) the amount used; and (4) the effect of the use on the market for the original work. 17 U.S.C. $\$ 107$ (1994); see also infra note 41.

10. See Campbell v. Acuff-Rose Music, Inc., 510 U.S. 569, 585 (1994). See infra note 279 for Justice Souter's critique. See also infra notes 50 and 52 for references to scholarly and other judicial critiques. 
require case-by-case analysis, ${ }^{11}$ the lower courts have drawn the conclusion that precedent has little utility and that every case should be treated as one of first impression. In a strange twist, the congressional attempt to enact the common law seems to have deterred the courts from employing common law reasoning. As a result, fair use "doctrine" benefits from neither the determinacy of a legislative mandate nor the contextual nuances of common law.

If the courts' legal method is confusing, their moral judgments seem patent. Every copier is a thief or a wise woman. In a judgment for the copyright holder, the judicial rhetoric often includes indignant allusions to the copier's greed or laziness im attempting to capitalize on another's creativity, while a judgment for the copier piously affirms the defendant's scholarly and selfless contribution to the expansion of knowledge. ${ }^{12}$ These moral characterizations appear to be rationalizations, added to make a borderline application of the four factors seem right. In any event, the rhetorical heat has impeded private agreements and contributed to draconian publishing contracts by depicting litigated fair use disputes as contests between thieves and wise men, rather than as difficult, and often principled, civil debates. As a result, only zealots with deep pockets can pursue the debate in the courts. ${ }^{13}$

On a deeper level, the felt need for this moralizing rhetoric reveals a flaw in the analytic framework. The courts, following the statutory structure, purport to evaluate fairness by an "objective" comparison of the role of the copied expression in the old and new work without making a value judgment about the relative literary merits of those works. ${ }^{14}$ But this disjunction is not possible. Under the current statute, a copier is a thief unless "fair use" justifies the taking. But what can justify the taking? If fairness is judged by comparing the works, then it must be that the quality of the new work justifies taking from the old work. And what can be the measure of quality? It must be a judgment that the public would be better off with the new work that mcludes the copied material. Making that judgment overtly, however, implicates judges' imtellectual and aesthetic judgment and taste, bases that many Americans, including judges, fear to be subjective and too dependant on class. Perhaps, then, the courts' evaluation of the quality of the copier's work is transmuted to a more

11. E.g., Campbell, 510 U.S. at 577.

12. Compare, e.g., Harper \& Row Publishers, Inc. v. Nation Enters., 471 U.S. 539, 542, 563, 564 (1985) (describing the Nation's editor working from a "purloined manuscript" in an effort to "scoop" a competitor; noting that fair use "'distinguishes between a true scholar and a chiseler"; characterizing the Nation's "clandestine" publication as "hastily patched together and contain[ing] 'a number of inaccuracies"') (citations omitted), with Sundeman, 142 F.3d at 202 (agreeing with the trial court that the copier's paper was "a scholarly appraisal ... from a biographical and literary perspective").

13. See infra Part II.A.

14. See infra note 81 . 
culturally acceptable evaluation of the copier's deeds and motives. This would explain, at least in part, the inoralizing rhetoric and the avoidance of explicit judgments of what works would serve the public.

The reluctance to address the relative quahty and value of expressive works may explain why these opinions seem so intensely argued, but nonetheless analytically flawed. This Article presents a close textual reading of the leading cases to illustrate this intensity and these analytic flaws, but more importantly, to advocate rhetorical restraint and analytic clarity in the future. Ultimately, my goals are three: 1) to analyze the interests involved in fair use disputes about unpublisled materials in a way that digs beneath the grounds that the judicial opinions now overtly recognize; 2) to urge that franker opinions would help rescue fair use of unpublished expression from the oblivion to which private law has consigned it; and 3) to advocate a more liberal and clearer doctrine in the service of accuracy and attendant thoughtful public consideration of sigmificant intellectual, moral, and aesthetic issues.

Blame for the unfortunate discourse of fair use may be widely spread. Congress sidestepped intractable competition annong interest groups by enacting a deliberately vague statute on fair use. ${ }^{15}$ Indefensible advocacy of substantial unpaid acadeinic use ahenated many, including academic authors, who might have otherwise supported a doctrine that provided more access. On the other side, large commercial copyright holders invoke "authors' rights" to camouflage their naked self-interest in increasing the protection for assets they already own. Commentators share responsibility by repeatedly, and futilely, advocating that a particular normative theory of property should inform Uinted States copyright law without first distilling from decisions the principles and factors that have influenced the modern decisions. ${ }^{16}$

Readers familiar with fair use may object that these are old issues and that a 1992 amendinent ${ }^{17}$ and subsequent cases have restored the fair use doctrine of unpublished materials and remedied the effects of the Second

15. See Kenneth D. Crews, Fair Use Of Unpublished Works: Burdens of Proof and the Integrity of Copyright, 31 ARIz. ST. L.J. 1, 45-53 (1999) (recounting the legislative debates leading up to the 1992 Amendment); Jessica D. Litman, Copyright, Compromise and Legislative History, 72 CorNeLL L. REv. 857, 860-61, 876-77 (1987) (describing the debates prior to the $1976 \mathrm{Act}$ ).

16. See, e.g., Ginsburg, supra note 3, at 7-10 (faulting some who attempt to diminish authors' rights on the grounds that they are a Romantic invention); Lloyd L. Weinreb, Fair's Fair: A Comment on the Fair Use Doctrine, 103 HARV. L. REv. 1137, 1140 (1990) (faulting Judge Pierre Leval for an exclusively utilitarian conception of copyright); see also infra note 91 . See Stewart E. Sterk, Rhetoric and Reality in Copyright Law, 94 MicH. L. Rev. 1197 (1996), for a useful summary of the debates over copyright's underlying values.

17. In 1992, Congress amended section 107 to include the sentence: "The fact that a work is unpublished shall not itself bar a finding of fair use if such finding is made upon consideration of all the above factors." Pub. L. 102-492, 106 Stat. 3145 (codified at 17 U.S.C. § 107 (1994)). See infra note 51 and accompanying text. 
Circuit's extraordinary Salinger v. Random House, Inc. ${ }^{18}$ decision. It is true that even the Second Circuit has retreated from an outright presumption against fair use of unpublished materials, but the later cases offer hittle comfort in result or reasoning. ${ }^{19}$ The use of a living writer's unpublished expression is as good as barred; if the uncertainty of judicial decisions does not deter the potential biographer, his publisher's contract surely will. And although a 1998 Fourth Circuit case ${ }^{20}$ suggests a welcome tolerance for using the unpublished writings of a now-deceased writer, the opinion minics the Second Circuit's earlier reliance on dicta from mapposite cases. ${ }^{21}$

Some readers may wonder whether the doctrines applicable to print materials will soon become obsolete, superseded by uniforn codes mandating automatic licensing for access to and use of electronic materials. Perhaps they will. I note, however, that debate over permissible unlicensed copying has persisted at least from the enactment of the Statute of Anne 22 through the imvention of many new technologies. However our new databases are configured and accessed, I suspect that biographers and scholars will still want to know whether they may quote from a subject's e-mail, for example. The ainount of money at stake in the relatively infrequent disputes over the use of unpubhished materials in traditional media is dwarfed by the sum at stake in the ongoing contest for rights to access and copy materials in digital media. Even so, the old issues remain important because they concern the interaction between personahty and property. The need to understand that interaction, and copyright's role in it, may become more, not less, important as new digital media and access tools blur the distinction between public, published work, and private, personal work. So, this old issue about the propriety of using someone else's expression will remain important even after musty archives have been converted to digits.

Given widespread anxiety about individual privacy in contemporary American culture, ${ }^{23}$ some readers may feel that, in difficult contests

18. 811 F.2d 90 (2d Cir. 1987).

19. See, e.g., Wright v. Wamer Books, Inc., 953 F.2d 231 (2d Cir. 1991).

20. Sundeman v. Seajay Soc'y, Inc., 142 F.3d 194 (4th Cir. 1998).

21. In a judgment permitting two copies (one complete copy, and the other copy containing all but six pages) and very extensive quotation of an unpublished novel, the Fourth Circuit relied heavily on dicta from Campbell v. Acuff-Rose Music, Inc., 510 U.S. 569 (1994). See Sundeman, 142 F.3d at 202, 206. Campbell addressed a very different issue: whether a parody of a published song was fair use. See Crews, supra note 15 , for a recent analysis of this line of cases, including Sundeman, that focuses on the intersection of privacy and traditional copyright interests.

22. 8 Ann., c. 19 (1710) (Eng.).

23. See Jonathan Franzen, Imperial Bedroom, NEw Yorker, Oct. 12, 1998, at 48 (describing the "new American obsession" with purported threats to individual privacy, but arguing that moderm Americans generally enjoy much more privacy than earlier generations did). Compare Jeffrey Rosen, "Is Nothing Private?", NEw YoRKer, June 1, 1998, at 36, 40-41 (arguing that our legal system regularly invades privacy and that the public seems not to mind very much). For legal analyses of the 
between claims of privacy against claims for public access, the balance should tip in favor of greater privacy. Such readers may see the logical missteps and the use of manipulative rhetoric described in this Article as a small price to pay for a desirable judicial expansion of copyright doctrine to protect privacy interests. Such a view reduces the issue to a contest of values between privacy and public access, and discounts the importance of how the courts make and express the normative choice.

Although this Article reflects a normative preference for public access more than contemporary doctrine and practice might afford, that normative argument is not the core of the Article. The core critique is that the courts have failed to make their value judgments sufficiently exphicit. Instead, im attempts to fit privacy into a traditional doctrinal paradigm that does not easily accommodate it, the courts have debased the discourse in the courts and in the publishing industry about the kinds of expression that should be protected and the mechanism that should be employed. In particular, the Supreme Court's opinion in Harper \& Row, Publishers, Inc. v. Nation Enterprises $^{24}$ supported a difficult judgment denying fair use by perceiving, in small aniounts of prose of very marginal originality, the feelings, subjective perspective, or elnotion of their author. Equating bits of expression with the writer's personal identity facilitated later attempts to protect the identity of the writer by commodifying the expression. ${ }^{25}$ The courts have never squarely faced the logical conclusion of this holding: that a true equation of every expression with the identity of the author would subject to the property-rights regime of copyright nearly every bit of expression written by an individual without regard to the author's interests in creating the expression or the qualitative or quantitative siginficance of the expression. Even more problematic is the courts' repeated assumption that "fact" can be distinguished from "expression." The courts have

actual or perceived threat and responses to privacy posed by the Internet, see Symposium, Cyberspace and Privacy: A New Legal Paradigm, 52 STAN. L. Rev. 987 (2000). In a particularly pertinent article, Professor Pamela Samuelson suggests that privacy might be better regulated under a trade secret paradigm rather than a traditional property paradigm. Pamela Samuelson, Privacy as Intellectual Property, 52 Stan. L. Rev. 1125, 1129 (2000).

24. 471 U.S. 539 (1985).

25. The outstanding example of such an attempt that proved successful and very influential was J.D. Salinger's writing. Salinger is the author of The Catcher in the Rye and a recluse. After discovering that he was the subject of a forthcoming biography that included quotations from his unpublished letters, Salinger rushed to register the letters for copyright and sued to enjoin publication of the biography. He succeeded in obtaining an injunction on the claim that the quotations infringed his copyright. Salinger v. Random House, Inc., 811 F.2d 90 (2d Cir. 1987). For a more in-depth discussion of Salinger's suit, see infra Part III.B.2.

26. In Harper \& Row, the Supreme Court at least acknowledged an unsettled legal issue conceming how to distinguish between uncopyrightable fact and copyrighted expression when the facts are "combined" with the expression. Unfortunately, the Court did not analyze the issue, concluding instead that the fact that the expression was quoted verbatim obviated the need to distinguish fact from expression. 471 U.S. at 548; see infra notes 191-193 and accompanying text. In Salinger, the Second 
overlooked an expression's potential to be fact or artifact. As a result, the courts seem unaware of the particular impediment to literary and historical biography and criticism created by a near blanket prohibition on presenting an individual's expression to the reader for close analysis. The courts' willingness to conflate property-rights arguments with privacy arguments has contracted fair use into a narrow range that no one imtended.

In fair use disputes, litigants argue over central human concerns such as work, thought, knowledge, freedom, property, identity, or privacy by using the strangely truncated vocabulary of copyright. The courts repeatedly fail to deal frankly with the intractable connection of expression and identity even though, in the area of unpublished materials, the courts are often more solicitous of the writer's identity and autonomy than of any measurable pecuniary interests. The courts seem confused, unable to think through these issues sufficiently. They adhere doggedly to the idea that United States copyright law serves only narrowly conceived utilitarian goals relating to financial incentives for creation, yet their judgments repeatedly reflect concern for the identity, autonomy, and privacy of writings not written for money. ${ }^{27}$ Even when they occasionally admit the relevance of interests, usually denoted by "privacy," they truncate any analysis by observing, first, that copyright law does not protect such interests, and second, that neither tort law nor contract protects such interests either. The opinions are flawed because the judges manipulate rhetoric to protect some unidentified interest. Although the interest is generally characterized as privacy, that usage is often imcorrect and misleading. The interest in expression that is often found in public archives rarely rises to the level protected by a claim for invasion of privacy. Sometimes the interest is one not expressly recognized under any doctrinal category, that is, in how one's own words are used truthfully by another to define oneself or one's work; at other times the asserted interest represents what I call a zone of privacy necessary to creativity.

The Article has five parts. Part I summarizes the current statutory and judicial doctrine of fair use within the United States, particularly as it applies to unpublished materials, and the argument that the doctrine disserves the public interest in copyright. This material has been anply covered by others and is included here to establish a franie of reference for the balance of the Article. Part II describes the private application of copyright doctrine within the trade publishing industry, concluding that private

Circuit was also confident that the biographer could report the facts adequately even if he could not quote Salinger. 811 F.2d at 100 . See infra note 224 and accompanying text.

27. E.g., Harper \& Row, 471 U.S. at 545 ("We agree with the Court of Appeals that copyright is intended to increase and not to impede the harvest of knowledge."). The Supreme Court's subsequent invocation of the author's personal identity rather than commercial incentives for authors is described in detail in Part III.B.1.b. For a related analysis of the Second Circuit decision in Salinger, see infra Part III.B.2.b. 
applications restrict uses even more than the already restrictive public doctrine would require. Part III presents the heart of the Article, describing how disingenuous judicial rhetoric in the 1980s, designed to rationalize close judgments involving the use of unpublished expression of living persons, effectively, if unwittingly, undermined the legal method in subsequent cases. Those cases undermined both the art and the accuracy of reputable biography and history by extending copyright to almost any expression arising from personal subjectivity while simultaneously contracting the scope of fair use. Part IV disputes recent judicial and scholarly claims that the doctrinal muddle generated by the 1980's opinions has been corrected, particularly by the Supreme Court's decision in Campbell v. Acuff-Rose Music, Inc. ${ }^{28}$ Part V offers a summary of the Article's argument and a suggestion for improving the analysis of disputes over the use of unpublished materials.

\section{I \\ The Current Doctrine of "Fair UsE"}

\section{A. Statutory Framework: Copyright Acts of 1909 \& 1976}

Under the Copyright Act of 1976, written expression enjoys automatic statutory protection from the moment it is set down, without regard to the writer's purpose in writing or the quantity or quality of the expression, subject only to a minimal requirement of "origmality."29 Pursuant to Article 1, section 8 of the United States Constitution, Congress exercised its power to extend statutory copyright to "origimal works of authorship fixed in any tangible medium of expression." 1977, the statute conveys to the copyright holder exclusive rights, including the right of first publication, ${ }^{31}$ that endure from the date of fixation to seventy years after the author's death. ${ }^{32}$ Unlike the Copyright

28. 510 U.S. 569 (1994).

29. The House Judiciary Committee report explains:

The phrase 'original works of authorship,' which is purposely left undefined, is intended to incorporate without change the standard of originality established by the courts under the present copyright statute. This standard does not include requirements of novelty, ingenuity, or esthetic inerit, and there is no intention to enlarge the standard of copyright protection to require thein.

Notes of Committee on the Judiciary, H.R. REP. No. 94-1476, at 51 (1976), reprinted in 1976 U.S.C.C.A.N. $5659,5664$.

30. 17 U.S.C. $\$ 102$ (a) (1994). Copyright does not extend to ideas, id. $\$ 102(b)$, or facts, Harper \& Row, 471 U.S. at 547 ("The copyright is limited to those aspects of the work-termed 'expression'that display the stamp of the author's originality.").

31. 17 U.S.C. $\$ 106(1994)$.

32. Id. § 302(a) (Supp. IV 1999). In 1998, Congress extended the basic term from life plus fifty years to life plus seventy years. The duration of the copyright term differs for works created prior to 1978, the effective date of the current Copyright Act, and for "works made for hire." 
Act of $1909,,^{33}$ the current Act extends statutory copyright protection to "original works"34 regardless of whether they are published or registered. ${ }^{35}$ The automatic conferral of statutory copyright at the moment of fixation of an "original work" expands the number and kind of works in which statutory copyright may be asserted. The prerequisites of publication or registration under the 1909 Act effectively limited statutory copyright to works that an author either self-consciously created for public dissemination or perceived to be worthy of copyright protection; as a result, statutory copyright was generally limited to works that the creator thought significant in some sense. Thus, although the formal threshold for copyrightability has always been low, the need to act affirmatively to secure statutory protection raised the bar. While unpublished writings generally enjoyed state cominon law or statutory copyright, which included a perpetual right to first publication, state copyright was subject to accidental forfeiture. ${ }^{36}$ In contrast, subject ouly to a minimal requirement of "originality,"37 the 1976 Act confers copyright upon many of the writings of a lifetime. This is so, even though the writer may not have drafted with a view to publishing or otherwise exploiting copyright, and even though the writings' exploitable value may derive less froin originality of expression than from the popular appetite for glimpses into private lives.

33. Copyright Act of Mar. 4, 1909, 35 Stat. 1075, repealed by General Revision of Copyright Law, Pub. L. No. 94-553, 90 Stat. 2541 (1976).

34. Copyright protection does not extend to "any idea, procedure, process, system, method of operation, concept, principle, or discovery, regardless of the form in which it is described." 17 U.S.C. $\S$ 102(b) (1994).

35. Section 12 of the 1909 Act permitted authors to register certain types of unpublished works. Under the 1909 Act, works that were neither registered nor published were generally protected by state law. See Litman, supra note 15 , at 884 \& n.179 (citing W. Strauss, Protection of UNPUBLISHED Works 8-15 (1957), reprinted in Subcomm. on Patents, Trademarks, and Copyrights of the Senate Comm. on the Judiciary, 86th Cong., 1st Sess., Copyright Law Revision (Comm. Print 1960)).

36. Litman, supra note 15 , at $884-85$ (citing Pushman v. New York Graphic Soc'y, 39 N.E.2d 249, 250-51 (1942)); see also Paul Goldstein, Copyright and the First Amendment, 70 CoLUM. L. REv. 983, 1004-06 (1970). Dissemination to an uncertain number of people, even without formal publication, might be deemed a publication and would result in forfeiture of the common law right. For example, in a relatively modern case, the New York Court of Appeals found that Ernest Hemingway was divested of any common law copyright he might have had in his conversations with an interviewer because of his failure to mdicate intent to retain the copyright. Estate of Hemingway v. Random House, Inc., 244 N.E.2d 250, 256 (N.Y. 1968). See generally Melville B. Nimmer \& David Nimmer, NiMMER ON COPYRIGHT, $\$ \S 4.03-4.04$ (1978).

37. See supra note 29. 


\section{B. The Debate Over Unpublished Materials and the Right of First Publication}

The expansion of statutory copyright coincided with substantial and persistent controversy about fair use ${ }^{38}$ in many contexts, ${ }^{39}$ including the use of unpublished materials. ${ }^{40}$ Section 107 of the 1976 Act purported to enact

38. Fair use has been variously characterized as a de minimis infringement, see, e.g., Sheldon v. Metro-Goldwyn Pictures Corp., 81 F.2d 49 (2d. Cir. 1936) (Learned Hand, J.); a defense to infringement, see William F. PATRY, The FaIR Use Privilege In Copyright Law 61 (1985); or a limitation on exclusivity, see Pierre N. Leval, Toward a Fair Use Standard, 103 HaRv. L. Rev. 1105, 1110 (1990); see also L. Ray Patterson, Free Speech, Copyright, and Fair Use, 40 VAND. L. REv. 1, 44 n.144 (1987) (observing that section 107 provides that "fair use . . . is not an imfringement").

39. See, e.g., Campbell v. Acuff-Rose Music, Inc., 510 U.S. 569 (1994) (rap parody of "Oh, Pretty Woman"); Feist Publ'ns, Inc. v. Rural Tel. Serv. Co., 499 U.S. 340 (1991) (copying of directory database); Harper \& Row, Publishers, Inc. v. Nation Enters., 471 U.S. 539 (1985) ("scoop" of "heart" of former President Ford's soon-to-be published memoirs); Sony Corp. v. Umiversal City Studios, Inc., 464 U.S. 417 (1984) (videotaping); Tasini v. New York Times Co., 192 F.3d 356 (2d Cir. 1999) (reprints of print articles in electromic media); Leibovitz v. Paramount Pictures, 187 F.3d 109 (2d Cir. 1998) (advertising parody of photograph); Ringold v. Black Entm't Television, Inc., 126 F.3d 70 (2d Cir. 1997) (use of art in television set); Dr. Seuss Enters. v. Penguin Books USA, Inc., 109 F.3d 1394 (9th Cir. 1997) (parody); Princeton Umv. Press v. Mich. Document Servs., 99 F.3d 1381 (6th Cir. 1996) (photocopying for course packs); Am. Geopltysical Union v. Texaco, Inc., 60 F.3d 913 (2d Cir. 1994) (inultiple copies of articles for m-house researchers); Basic Books, Inc. v. Kinko's Graphics Corp., 758 F. Supp. 1522 (S.D.N.Y. 1991) (photocopying for use im course packs).

40. The distimction between published and unpublished material can be problematic. Indeed, one reason the 1976 Copyright Act conferred statutory protection upon works at "fixation" was to avoid occasional disputes, like those under the earlier Act, concerning the date of publication of works that were disseminated without a typical commercial publication process. The 1976 Act does not define "published" but it does define "publication." Section 101 provides in part:

"Publication" is the distribution of copies or phonorecords of a work to the public by sale or other transfer of ownership, or by rental, lease or lending. The offering to distribute copies ... to a group of persons for purposes of further distribution, public performance, or public display, constitutes publication. A public performance or display of a work does not of itself constitute publication.

....

To perform or display a work "publicly" means - (1) to perform or display it at a place open to the public or at any place where a substantial number of persons outside of a normal circle of a family and its social acquaintances is gathered; or (2) to transmit or otherwise communicate a performance or display of the work to a place specified by clause (1) or to the public, by means of any device or process, whether the members of the public capable of receiving the performance or display receive it in the same place or in separate places and at the same time or at different times.

17 U.S.C. $\S 101$ (1994). Besides Harper \& Row, cases mvolving unpublished materials include Sundeman v. Seajay Society, Inc., 142 F.3d 194 (4th Cir. 1998) (photocopying for archival and research and quotation in scholarly article of unpublished novel); Norse v. Henry Holt \& Co., 991 F.2d 563 (9th Cir. 1993) (quotation of unpublished letters im biography of a different author); Wright $v$. Warner Books, Inc., 953 F.2d 731 (2d Cir. 1991) (small quotations in a biography of author's unpublished diaries and letters); New Era Publications International v. Henry Holt \& Co. (New Era I), 873 F.2d 576 (2d Cir. 1989), reh'g denied, (New Era II) 884 F.2d 659 (2d Cir. 1989) (quotations in a critical biography from church leader's unpublished joumals); Salinger v. Random House, Inc., 811 F.2d 90 (2d Cir. 1987) (quotations and paraphrasing of author's unpublished letters in a biography); Religious Technology Center v. Netcom On-Line Communication, 923 F. Supp. 1231 (N.D. Cal. 1995) (on-lime excerpts of churcli lcader's unpublished works); Religious Technology Center v. Lerma, 897 F. Supp. 260 (E.D. Va. 1995) (quotations of unpublished religious documents obtained by newspaper from court records); Lish v. Harper's Magazine Foundation, 607 F. Supp 1090 (S.D.N.Y. 1992) (verbatim reprint 
the previous common law doctrine of fair use as a limitation on exclusive copyright. ${ }^{41}$ The common law doctrine was traditionally defined as "a privilege in others than the owner of the copyright to use the copyrighted material in a reasonable manner without his consent." ${ }^{\text {"42 }}$ The conventional utilitarian rationale for fair use is that new writers must necessarily build upon, borrow from, or comment on earlier works in order to create new works. In this view, fair use doctrine would ideally maximize the number of new works by taking that portion of existing copyrights necessary to facilitate or subsidize their creation. ${ }^{43}$

By its terms, section 107 arguably subjected all the exclusive rights, including the right of first publication, to fair use. In Harper \& Row, Publishers, Inc. v. Nation Enterprises, however, the Supreme Court held that fair use did not apply "in pari materia" The Court found that to permit the use of materials before publication jeopardized the copyright holder's proprietary interest in exploiting the right of first publication. The Court reasoned that if users were permitted to

in magazine of portions of author's letter to students). The distinction between published and unpublished is not the only source of debate over the extent of copyright protection for things that partake of the quality of "work" and also of "personality." There is some tendency to extend common law copyright protection to intangible works, such as performances, on the theory that they are analogous to works of authorship. But see David W. Melville \& Harvey S. Perlman, Protection for Works of Authorship Through the Law of Unfair Competition: Right of Publicity and Common Law Copyright Reconsidered, 42 ST. LouIs U. I.J. 363, 366 (1998) (arguing that common law copyright with its "encrusted concept of publication should no longer be applied" at least for works that are "unfixed" in tangible form).

41. The 1976 legislation was "intended to restate the [pre-existing] judicial doctrine of fair use, not to ehange, narrow, or enlarge it in any way." H.R. REP. No. 94-1476, at 66 (1976), quoted in Harper \& Row, 471 U.S. at 549. Section 107 provides in full:

Notwithstanding the provisions of sections 106 and 106A, the fair use of a copyright work, including such use by reproduction in copies or phonorecords or by any other means specified by that section, for purposes such as criticism, comment, news reporting, teaching (including multiple copies for classroom use), scholarship, or research, is not an infringement of copyright. In determining whether the use made of a work in any particular case is a fair use the factors to be considered shall include-

(1) the purpose and character of the use, including whether such use is of a commercial nature or is for nonprofit educational purposes;

(2) the nature of the copyright work;

(3) the amount and substantiality of the portion used in relation to the copyright work as a whole; and

(4) the effect of the use upon the potential market for or value of the copyrighted work.

The fact that a work is unpublished shall not itself bar a finding of fair use if such finding is made upon consideration of all the above factors.

17 U.S.C. $\$ 107$ (1994) (emphasis added). Congress added the final sentence in 1992 in reaction to the Second Circuit's Salinger and Wright decisions. See infra note 51 and accompanying text.

42. H. Ball, LAw of Copyright and Literary Property 260 (1944), quoted in Harper \& Row, 471 U.S. at 549.

43. See Campbell, 510 U.S. at 580, 583, 588; Harper \& Row, 471 U.S. at 549.

44. The phrase is defined as "upon the same matter or subject." BLACK's LAw Dictionary (6th ed. 1991). As used by The Nation, the phrase seems to mean that unpublished material should be treated under the statute "in the same way" as published material.

45. Harper \& Row, 471 U.S. at 552. 
"scoop" a work-in-progress, the author would be deprived of control over the form in which the material would first be presented to the public, and both author and publisher might go uncompensated for the effort of revising and pohshing a quality work. ${ }^{46}$ In dicta that still preface every opinion on the fair use of unpubhshed materials, the Court wrote: "[t]he fact that a work is unpublished is a critical element of its 'nature.' Our prior discussion establishes that the scope of fair use is narrower with respect to unpublished works."47

Shortly thereafter, the Second Circuit almost killed fair use of unpublished materials by relying on this dicta in Salinger $v$. Random House, Inc., ${ }^{48}$ a wholly distinguishable case involving a biographer's attempt to quote or paraphrase letters that J. D. Salinger wished to withhold from public view. Careless about precedent, the Second Circuit's subsequent opinions in the New Era cases applied dicta as though they represented holdings and created a presumption against fair use for unpubhished materials. ${ }^{49}$ These cases intimidated biographers, historians, and journalists, and drove publishers to adopt extremely restrictive guidelines for fair use. ${ }^{50}$

Congress responded in 1992 by amending section 107 to provide that "[ $t]$ he fact that a work is unpublished shall not itself bar a finding of fair use if sucl finding is made upon consideration of all of the above factors." $"$ In the intervening years the seminal cases, Harper \& Row and

46. Id. at 552-55.

47. Id. at 564 (citations omitted).

48. 811 F.2d 90 (2d Cir. 1987).

49. See New Era Publ'ns Int'1 v. Henry Holt \& Co. (New Era I), 873 F.2d 576 (2d Cir. 1989), reh'g denied, (New Era II) 884 F.2d 659 (2d Cir. 1989). In the Henry Holt litigation, the majority and concurring opmions in the New Era I and the majority and dissenting opinions in New Era II engaged in a bizarre public debate over whether any use of unpublished materials could be fair despite both sides' recognition that the entire debate was dicta because the case had been disunissed on laches. See New Era I, 873 F.2d at 577; id. at 585 (Oakes, J., concurring); see also New Era II, 884 F.2d at 660; id. at 662 (Newman, J., dissenting).

50. See, e.g., David A. Kaplan, The End of History?, NewsweEk, Dec. 15, 1989, at 80 (describing the difficulty posed to investigative journalism by the Salinger restriction on using unpublished material); Steven Pressman, Fouling Up Fair Use, Colum. JourNalism Rev., Jan.-Feb. 1994, at 44. Cf. Jon O. Newman, Not the End of History: The Second Circuit Struggles with Fair Use, 37 J. Copyright Soc'y 1 (1990) (arguing that the Salinger decision did not ban all use of unpublished material at lcast where necessary to establish a fact). Judge Newman further articulated his views in New Era II, 884 F.2d at 663, when he dissented from denial of a petition for rehearing en banc on the ground that the Second Circuit's dicta would have an excessively chilling effect on the use of unpublished materials.

51. Pub. L. No. 102-492, 106 Stat. 3145 (Oct. 24, 1992). Although Congress amended the statute in 1992 to provide that section 107 did indeed apply to unpublished materials, Congress did not specify any new criteria for determining fair use of unpublished material, but simply reiterated the relevanee of section 107. At most, then, the amendment invited the courts to reconsider broad application of language from Harper \& Row, for example, "[t] of its 'nature," and "the scope of fair use is narrower with respect to unpublished works." 471 U.S. at 564, quoted in Salinger v. Randoin House, Inc., 811 F.2d 90, 97 (2d Cir. 1987). 


\section{Salinger, have been criticized, ${ }^{52}$ and even the Second Circuit has returned to permitting some fair use of unpublished material..$^{53}$ Nevertheless, no}

The amendment, like the original text, seems to mandate consideration of the four enumerated factors without specifying the nature or consequences of that consideration. It does not seem to require any particular type of consideration, such as a counting of favorable factors or weighing of the factors' relevance; nor does it technically preclude rejection of some or all of the enumerated factors in favor of other unenumerated factors provided only that the enumerated factors are first considered. The statute confers upon the court a peculiar form of discretion. At first blush, it resembles a "weak form of discretion," as defined by Dworkin. Ronald Dworkin, TAKINg Rights SERIouSLy 3 I-32 (1977). In Dworkin's example, a sergeant ordered to select his "five most experienced men" has "weak" discretion, that is, he is authorized to exercise some independent judgment to implement an order that sets a standard (however vague). Dworkin contrasts "strong discretion" as discretion (apparently of an agent) that is not bound by standards set by an authority (or principal).

The difficulty with defining the degree of discretion afforded the courts by this statute has two elements. First, since the statute purports only to restate common law and affirm the relevance of some sort of future common law decision making, it is impossible to be certain whether Congress is the primcipal setting the standard for the courts, as would be typical of most legislation, or whether the courts remain the principals who have established and will continue to establish the standard for fair use. If the latter, then it is difficult to say what the status of the four factors might be, either as factors that the courts must consider henceforward, or as descriptive of the type of common law considerations the courts have used and may continue to follow or revise as they in their discretion see fit. Second, the statute defines only one normative standard, that the use be "fair." The requirement to consider the four factors sets a standard for the decision-making process, but not the decision itself. Under traditional notions of separation of powers, however, the courts must have discretion to determine their own processes so the mandate, if that is what it is, is of questionable constitutional vahidity. If, on the other hand, the statute is merely suggestive of considerations that may be discarded after a moment's consideration, it is essentially meaningless. And yet, by intervening in 1992 with the amendment, Congress indicated quite clearly that it intended to exercise not only legislative supremacy over the definition of which uses were fair but, arguably, also over the weight that the courts could attribute to any one of the factors they must "consider." So, it is difficult to state what sort of discretion the courts now have, both over the standard of fair use and the decision-making process for determining whether that standard is met.

In any event, the courts have exercised their discretion timidly. See, e.g., Wright v. Wamer Books, Inc., 953 F.2d 731, 737 ( $2 \mathrm{~d} \mathrm{Cir.} \mathrm{1991)} \mathrm{("Where} \mathrm{use} \mathrm{is} \mathrm{made} \mathrm{of} \mathrm{materials} \mathrm{of} \mathrm{an} \mathrm{unpublished} \mathrm{nature,} \mathrm{the}$ second fair use factor has yet to be applied in favor of an infringer, and we do not do so here.' ... Our precedents, then, leave little room for discussion of this factor once it has been determined that the copyrighted work is unpublished." (quoting New Era I, 873 F.2d at 583)); Lish v. Harper's Magazine Found., 807 F. Supp. 1090, 1101 \& a.10 (S.D.N.Y. 1992) (relying on the quoted language from Wright and noting further that, even if the 1992 amendment of section 107 were applicable, "it would not produce a different result $\mathrm{m}$ this case").

52. See, e.g., Crews, supra note 15; William W. Fisher III, Reconstructing the Fair Use Doctrine, 101 HARV. L. REV. 1661, 1789-95; Wendy J. Gordon, Toward a Jurisprudence of Benefits: The Norms of Copyright and the Problem of Private Censorship, 57 U. CHI. L. REv. 1009, 1041 (1990) (reviewing Paul Goldstein, Copyright: Principles, LAw and Practice (1989)); Leval, supra note 38 at 111722; Pierre N. Leval, Nimmer Lecture: Fair Use Rescued, 44 UCLA L. Rev. 1449 (1997); Litman, supra note 15, at 897-98; Newman, supra note 50; New Era II, 884 F.2d at 663 (dissenting opinion). Despite these judges' and scholars' agreement that privacy, per se, ought not to receive statutory copyright protection, this Article maintains that the presence of any explicit or implicit privacy interest (however loosely defined) has shifted, and will continue to affect, the courts' perception of the equities in a fair use analysis. This Article urges advocates and the courts to deal frankly with the problem of "privacy" rather than distort fair use analysis by employing rhetoric designed to camoufiage the impact "privacy" interests play.

53. E.g., Wright, 953 F.2d at 740. The Fourth Circuit has followed suit. Sundeman v. Scajay Soc'y, Inc., 142 F.3d 194, 204-05 (4th Cir. 1998). 
Circuit has yet questioned the Supreme Court's dictum that "the scope of fair use is narrower with respect to unpublished materials." 54 While the more recent decisions have avoided the Second Circuit's misguided reliance on dicta im Salinger and the New Era cases, they, too, have failed to articulate coherent principles of decision. Instead, the subsequent cases dutifully recite that fair use is an "equitable rule of reason" that must be apphed on a "case-by-case basis." "5s They then plod through the four statutory factors. ${ }^{56}$ These cases then briefly distinguish Harper \& Row, pointing to the Supreme Court's evident disapproval of the publisher's conduct, as indicated by its use of such terms as "purloined," "chiseler," and "scoop." Salinger is passingly distinguished on the ground that the quotes, unlike Hamilton's quotes from Salimger's letters, did not "make the book worth reading." 58 I think it siguificant that these distinctions rest on the earlier courts' concerns for facts that are not, at least overtly, pertinent to the statutory four factors. Ironically, dicta has become holding.

\section{A Façade of Doctrinal Coherence: Campbell v. Acuff-Rose Music, Inc.}

Some commentators now believe that doctrinal confusion is a thing of the past. Judge Leval, who presided over Salinger in the district court, and who has written influential articles on fair use, expressed confidence that the Supreme Court's decision in Campbell v. Acuff-Rose Music, Inc. ${ }^{59}$ has provided a coherent principle. He writes that Campbell has "dispelled all

54. Harper \& Row, 471 U.S. at 564. The Second Circuit struggled to interpret this phrase and, in the author's opinion, got it wrong. See infra Part III.B.2. Robert Nagel argues that in the United States we tend to avoid hard moral issues and profound political disagreement by consigning such issues to the courts. Robert F. NAGel, Judiclal Power and American Character 4 (1994) ("I do not argue that judicial review is a necessary response to a sense of noral inadequacy or that judicial review can function only as a reaction to cultural anxiety. I merely claim that this is one of the main uses to which we put the courts in the modem era.") Nagel also faults the courts for participating in the cultural avoidance of tough issues by writing opinions laden with technical elite phraseology designed to obscure the true disagreement about values. Although Nagel does not address copyright issues, his critique is relevant. A serious, ongoing disagreenent about values characterizes the ongoing litigation of fair use and the outpouring of scholarly and journalistic discussion of copyright and fair use issues, particularly in the "information age."

55. E.g., Sundeman, I42 F.3d at 202; Wright, 953 F.2d at 735.

56. E.g., Sundeman, 142 F.3d at 202-08; Wright, 953 F.2d at 736-40.

57. See, e.g., Wright, 953 F.2d at 737 (stating that the defendant's "conduct bore no similarity to the sharp practices condemned in Harper \& Row where '[t]1e trial court found that The Nation knowingly exploited a purioined manuscript"'); Wright, 953 F.2d at 743 (Van Graafeiland, J., concurring) ("For purposes of stare decisis, it also is unfortunate that the conduct of the defendant in Harper \& Row] was of such a nature as to elicit from the Court such condemnatory words as 'scooped', 'pirated', 'exploited", 'purloined', 'clandestine', and 'chiseler."'); cf. Sundeman, 142 F.3d at 203-04 (noting that the defendant lad no "exploitative motive" or intention of "usurping the ... right of first publication").

58. Wright, 953 F.2d at 738-39. Sundeman barely distinguishes Salinger at all. At most one can infer the distinction that the defendant's scholarly agenda justified substantial takings wlile Hamilton's biographical agenda did not. See Sundeman, 142 F.3d at 205-06.

59. 510 U.S. 569 (1994). 
those unhelpful slogans from the fair use discussions"; "[Campbell] has refocuse[d] the fair use doctrine on the central purpose of copyright [to bring intellectual enrichment to the public]." ${ }^{10}$ Leval praises the opinion for underscoring the "interdependence of the first and fourth factors": 61

The fourth factor looks at the harm which the secondary work may do to the copyright market of the original by offering itself as a substitute (for either the original or its derivatives). The first factor looks primarily at whether the use made of the original seeks to transforn the taken material into a new purpose or message, distinct from purposes of the original. It follows logically that the more the appropriator is using the material for new transformed purposes, the less likely it is that appropriative use will be a substitute for the original, and therefore the less inipact it is likely to have on the protected market opportunities of the original. ${ }^{62}$

While Justice Souter's majority opinion in Campbell cited Leval's article for the proposition that fair use should depend largely on whether the use was "transformative," infuse fair use doctrine with coherence. Although both Justice Souter's opinion and Leval's reasoning make sense in context, neither eliminates the risk that in a different context the lower courts may seize upon "transformative" use just as eagerly and just as inappropriately as they have earlier seized on other supposed principles of fair use doctrine. Just as the Second Circuit mistook persuasive rhetoric for general primciple, postCampbell courts may also succumb to facile reliance on "transformative" use without serious factual analysis. Indeed, the Fourth Circuit appears to have done just that recently. ${ }^{64}$

60. Pierre N. Leval, Campbell v. Acuff-Rose: Justice Souter's Rescue of Fair Use, 13 CARDozo ARTS \& ENT. L.J. 19, 22 (1994).

61. Id. Again, the fair use factors, in brief, are: (1) the nature of the use; (2) the nature of the original copyrighted work; (3) the amount used; and (4) the effect of the use on the market for the original work. Supra note 9.

62. Leval, supra note 60 , at 22-23.

63. Campbell, 510 U.S. at 576 (citing Pierre N. Leval, Toward a Fair Use Standard, 103 Harv. L. REV. 1105,1110 (1990)).

64. Sundeman v. Seajay Soc'y, Inc., 142 F.3d 194 (4th Cir. 1998). The Fourth Circuit seems to assume that the genre, scholarly criticism, ensnred that the use was transformative. For example, the appellate court discounts the scholar's substantial quotation and paraphrase without any examination of whether the scholar had "transformed" the quotes or otherwise demonstrated a need for specific quotes. Instead, the court generalizes, stating that "[i]t seems apparent that a scholarly criticism of a book will require the critic to quote and paraphrase from the work it is analyzing." $1 d$. at 206. The court does not examine the meaning of the quotes, but contrasts their quantity favorably with amounts allowed in cases involving quotes from published materials. It is not obvious why the generalization is valid for the transposition of fictional material into scholarly criticism while it is not valid for the transposition of correspondence into biography. In fact, the Fourth Circuit's summary treatment of this issue has not heeded the Supreme Court's more discriminating caution in Campbell that parody, as a genre, could not be deemed presumptively fair, 510 U.S. at 581 . Two recent cases that illustrate the difficulty of distinguishing "transformative" from infringing parody are discussed at infra note 288. 
Moreover, Leval's "transformative" standard remains vague and still fails to recognize or remove the underlying reason for the courts' tendency to revert to dicta for resolving tough cases. This is due to the courts' reluctance to engage in any frank discussion of non-proprietary interests in literary expression. ${ }^{65}$ I very much doubt that the Second, or any other Circuit, has been unable to distinguish dicta from holding. Instead, a tendency to latch on to dicta of inapposite cases and use it as an outcome indicates a doctrinal problem: the courts are inclined to sacrifice reasoned explanation for imdirect rhetorical strategies that invoke, but do not examine, values such as privacy. This disregard for legal method seems most likely to occur when a harried court feels it lacks an appropriate primciple or other analytic structure to justify an outcome it intuits is equitable on the facts. ${ }^{66}$

\section{Recommendations for Reform: Injecting Determinacy into Fair Use Doctrine}

A sustained effort is necessary in order to inject some determinacy into the doctrine of fair use in order to provide sanctuary for those serious writers and scholars who have the most legitimate reasons for testing the boundaries of fair use but who lack the resources to defend an infringement action.

\section{Rejecting the Presumption Against Fair Use of Unpublished Materials}

In particular, the courts should cleanly reject any remnant of a presumption or bias against the fair use of unpublished materials. I agree,

65. In 1990, Professor Lloyd Weinreb criticized Leval's article for exactly this reason:

My principle [sic] disagreement is that [Leval] would construe the fair use doctrine strictly according to the utilitarian premises of the copyright scheme as a whole, to the exclusion of every other consideration. Copyright, he urges, is intended to promote the production and dissemination of works of creative authorship. It has no aspect as property independent of that purpose. Accordingly, whether a use that would otherwise infringe copyright is a fair use or not depends in the first instance on whether that purpose would be served.

Weinreb, supra note 16 , at 1140 .

66. Weinreb writes:

Much as I sympathize with the spirit behind these efforts to bring order out of chaos, I think they considerably mistake what fair use is all about. Although much of the confusion and cross-purpose that has characterized jurisprudence on this subject is unnecessary, I doubt that the results in concrete cases can be made predictably responsive to a limited set of defimite principles-certainly not large, general principles and not very often even inore specific, mtennediate ones. ... What is fair is as fact-specific and resistant to generalization in this context as it is in others. Development of the doctrine of fair use ought to proceed, therefore, not by deduction from principle but by induction from concrete eases.... On that basis, furthernore, the Supreme Court's much criticized decisions in the Sony and Harper \& Row... cases were probably correct.

Id. at 1138 (footnotes omitted). This Article takes Professor Weinreb's cominent one step further to suggest that the effort to reason from principle has failed in part because the courts have not even articulated the operative principles frankly. Beyond that, I agree that the courts' doctrinal analysis would be more deterninate if induced from the holdings of concrete cases. See my discussion of Campbell v. Acuff-Rose Music, Inc. in Part IV.B. for an attempt at just such an induction. 
in part, with Professor Crews's recent suggestion that plaintiffs should have the burden of proof to establish that a particular writing was intended for publication or was intended to be private ${ }^{67}$ But I go further. Professor Crews's suggestion does not tell the courts what to do if a plaintiff carries the burden of establishing an intention of "privacy." An appellate court will still need language to openly evaluate the meaning to be accorded that intent vis-à-vis the public's interest in reading the new work with the quoted material. Despite Professor Weinreb's doubts that the goal can be achieved, Parts I, IV, and V of this Article attempt to define factors, or indicia, of fair use specifically tailored to that subset of unpublished materials, such as letters and diaries, that the original author may never publish or license. These indicia are drawn from a detailed analysis of both the holdings and rhetoric of the leading cases on unpublished materials. ${ }^{68}$

In a nutshell, I urge the courts to forgo dogged allegiance to section 107 's four factor structure of analysis, at least in hard cases, and engage in frank recognition that the hard cases present a real and important conflict among a "new" writer's intellectual and aesthetic interest in accurately documenting his analysis of events, character, or even the writings theinselves; the reading public's parallel interest in having access to sufficient portions of the relevant writings to engage im reasoned assessment and debate about the scholar's conclusions; and the original author's, or copyright holder's, often profound personal interest in withholding or limiting the dissemination of his own words. The courts should abandon any pretense that the calculus here can be purely utilitarian. At the same time, the courts need to adopt a more sophisticated utilitarian analysis of the public interest in this issue. Specifically, the near abolition of fair use for unpublished materials encourages biographers and scholars to substitute assertion for proof, and unrepresentative snippets or paraphrases for substantial quotes with context. Ultimately this deprives the reading public, the scholar, and even the subject of the study the opportunity for reasoned debate. If there is no data from which to draw diverse inferences, there can only be assertions. More generally, excessive bars to quotation may influence scholars to prefer dead over living subjects and flattery over analysis.

It is equally important to acknowledge the difficult challenges that courts encounter when evaluating the very serious affront to personal

67. Crews, supra note 15, at 68-80. I doubt Professor Crews's proposal for some 'burdenshifting" adequately protects the public interest in access. While his suggestion will no doubt help the courts cleanly distinguish between cases where the copyright holder alleges injury to a commercial interest from cases alleging an injury to personal interests, it does not indicate how the courts should balance the interests in the latter type of case. Indeed, Crews's proposal leaves open the possibility that a plaintiff could merely assert a privacy interest, possibly by personal affidavit, to trump a "fair use" defense. That seems to me to leave plaintiffs in just about the same position they enjoy now, with a nearly unilateral censorship power to suppress embarrassing facts if the user attempts to validate the facts with the plaintiff's own written expression.

68. See infra pp. 443-44, 452-53. 
identity posed by the dissemination of one's words. A doctrine of fair use that tolerates unreasonable intrusions into privacy or dignity may backfire, motivating writers to destroy private papers that they would otherwise leave intact had they the assurance that the papers would not be quoted until seventy years after the writer's death. On the other hand, a presumption against fair use of unpublished materials can lead to unjustified censorship. For example, the present state of the law allows the famous subject of a potential biography to use copyright to control her public image and to engage in rent-seeking, extracting licensing fees for expression that is merely the by-product of a life. By denying permission or charging high licensing fees, the copyright holder can not only protect the creator's privacy but can also modnlate her publicity by granting permission to copy to flatterers and denying permission to critics.

If the courts were to reject the current presumption against the fair use of unpublished materials, ${ }^{69}$ fair use wonld apply "in pari materia" to published and unpublished works. ${ }^{70}$ As many cominentators have noted, the generic category of "unpublished" obscures important differences in how copyright may affect the creation of writing and the interests of the creator. ${ }^{71}$ Whether a given use impacts pecuniary or personal interests depends in large part on whether the creator of the original work is about to publish, hopes to pubhsh, or expects to withhold the work. An unlicensed use that would likely lower the creator's and first publisher's expected return would presumably lessen the creator's incentive to complete and disseminate the work. In such a case, the second fair use factor, the nature of the orignial copyrighted work, would weigh against a finding of fairness. ${ }^{72}$ Thus, as the Supreme Court explained in Harper \& Row, the unlicensed use of a soon-to-be-published manuscript arguably threatens the creator's imcentive to publish the work, ${ }^{73}$ diminishes her ability to exploit first pubhication rights, and may allow the user to free-ride on the first

69. See supra note 51 .

70. But see Harper \& Row, Publishers, Inc. v. Nation Enters., 471 U.S. 539, 552 (1985) (rejecting defendant's argument that fair use would apply in pari materia to published and unpublished works).

71. E.g., Crews, supra note 15; Fisher, supra note 52, at 1171-72; Gordon, supra note 52, at 1041; Leval, supra note 38, at 1125-30.

72. See Leval, supra note 38 , at 1117 (noting that works, including drafts, made for possible publication are "at the heart" of the copyright purpose and should get more protection than unpublished letters, lists, etc.). In most cases, the fourth fair use factor, the effect of the use on the market for the original work, would also weigh against a finding of fairness.

73. In Harper \& Row, the Court emphasized that the right of first publication protects the author and first publisher's right to initiate, prepare and "groom [ ] . . [a work] for public dissemination." 471 U.S. at 555. "The obvious benefit to author and public alike of assuring authors the leisure to develop their ideas free from fear of expropriation outweighs any short-term 'news value' to be gained from premature publication." Id. (citing Paul Goldstein, supra note 36, at 1004-06 ("The absolute protection the common law accorded to soon-to-be published works '[was] justified by [its] brevity and expedience."')). 
publisher's development costs. ${ }^{74}$ In contrast, letters and other incidental writings are presumably written and completed without a commercial motivation, or at least prior to the recognition of a financial interest. ${ }^{75}$ Thus, an unlicensed use will rarely affect the creator's incentive to create such writings.

\section{Reaffirming Statutory Copyright to "Works of Authorship"}

In addition, the courts and the copyright industry ought to take more seriously the statutory grant of copyright to original "works of authorship."76 The courts have slipped into a fallacy. In cases involving unquestionably copyrighted "works," courts typically analyze the portion of a copyrighted work that a user may fairly copy with the result that even very small bits of original expression, particularly those constituting the heart of a long work, may be protected. ${ }^{77}$ From this, the courts have assumed, without analysis, that small bits of unpublished expression qualify for copyright protection without examining whether they are embodied in a work of authorship; the courts look only to whether the expression is original and non-factual. ${ }^{78}$ The question, for example, of

74. Harper \& Row, 471 U.S. at 555, 557; see also William M. Landes \& Richard A. Posner, $A n$ Economic Analysis of Copyright Law, 18 J. LeGAL STUD. 325, 328 (1989).

75. Obviously, some creators, particularly those who are already famous and those with great expectations of becoming famous may self-consciously write "incidentals" with an eye to future publication. In such cases, it is simple enough for the creator to manifest that motivation by registering the writings and by instructing recipients not to disseminate the materials.

76. 17 U.S.C. $\S 102$ (a) (1994); see also H.R. REP. No. 94-1476 (1976), reprinted in 1976 U.S.C.C.A.N. 5659 (defining what constitutes an "original work[ ] of authorship"). The House Report further elaborates:

In using the phrase "original works of authorship," rather than "all the writings of an author" now in section 4 of the statute..., the committee's purpose is to avoid exhausting the constitutional power of Congress to legislate in this field, and to eliminate the uncertainties arising from the latter phrase. Since the present statutory language is substantially thc same as the empowering language of [Article 1, section 8 , clause 8 of] the Constitution, a recurring question has been whether the statutory and the constitutional provisions are coextensive. If so, the courts would be faced with the alternative of holding copyrightable something that Congress clearly did not intend to protect, or of holding constitutionally incapable of copyright something that Congress might one day want to protect. To avoid these equally undesirable results, the courts have indicated that "all the writings of an author" under the present statute is narrower in scope than the "writings" of "authors" referred to in the Constitution.

Id. Section 101 defines "literary works" as "works ... expressed in words, numbers, or other verbal or numerical symbols or indicia, regardless of the nature of the material objects... in which they are embodied." 17 U.S.C. § 101. "Works" is not a defined term.

77. Harper \& Row, 471 U.S. at 564-65.

78. See id.; Salinger v. Random House, Inc., 650 F. Supp. 413, 419-20 (S.D.N.Y. 1986) (Leval, J.). But see Wright v. Warner Books, Inc., 953 F.2d 731, 741-43 (2d Cir. 1991) (Van Graafeiland, J., concurring) (questioning whether sniall excerpts from Richard Wright's letters and diaries were copyrighted at all, either beeause the expression was factual, stereotypical, or the amount copied was "de minimis"). In theory, copyright protection does not extend to facts or ideas. Feist Publ'ns, Inc. v. Rural Tel. Serv. Co., 499 U.S. 340 (1991). In practice, the distinction is difficult and litigated. For a summary of scholarship and a helpful analysis of recent Second Circuit cases, see lrene Segal Ayers, 
whether a sentence from a letter, or a group of unrelated sentences from disparate letters, constitutes a work or works of authorship is not addressed. Indeed, the unstated assumption seems to be almost retrospective. Because a collection of a writer's letters is generally regarded as a "work," the courts seem to assume that each discrete letter, and each sentence or phrase within, qualify as "works." the effects of automatic copyright, this fallacy effectively means that the courts will assume that just about any sequence of written words, if fixed and original, is copyrighted without any reference to authorial intent or a reasonable reader's perception of what legitimately constitutes a work. Thus, if I chose to write a shopping list with unusual phrasing, I may claim it is copyrighted. ${ }^{81}$

\section{Reconfiguring the Statutory Factors}

To begin their analysis, courts should examine the following factors before even deciding whether and to what extent the four factors in section 107 are pertinent. These initial factors to be considered are: (1) whether a reasonable person would conclude that the expression constitutes a "work" or is part of a "work" of original expression; (2) whether at any time before the challenged use, the creator had any intention to publish or exploit the expression; (3) whether at the time of the proposed use the work is coinpleted or whether it is a work in progress; (4) whether the creator hopes to withhold the work and, if so, what steps she has taken to

Comment, The "Facts" of Cultural Reality: Redrawing the Line Between Fact and Expression in Copyright Law, 67 U. CIN. L. REv. 563 (1999).

79. One could argue that such a collection is primarily the "work" of the researcher and editor.

80. See infra note 225 and accompanying text.

81. The courts consistently assert that copyrightability does not depend on literary taste or value. For example, in finding that 2 Live Crew's rap parody of "Oh, Pretty Woman" was parody and permitted as fair use, the Supreme Court noted:

[W] will not take the further step of evaluating its quality. The threshold question when fair use is raised in defense of parody is whether a parodic character may reasonably be perceived. Whether, going beyond that, parody is in good taste or bad does not and should not matter to fair use.

Campbell, 510 U.S. at 582 (footnote omitted). The Court goes on to quote Justice Holmes: "[i]t would be a dangerous undertaking for persons trained only to the law to constitute themselves final judges of the worth of [a work], outside of the narrowest and most obvious limits." Id. (quoting Bleistein v. Donaldson Lithographing Co., 188 U.S. 239, 251 (1903) (finding that circus posters were copyrighted over an argument that the posters' quality did not warrant copyright)). See infra note 301 and accompanying text; see also New Era Publ'ns Int'l v. Henry Holt \& Co., 884 F.2d 576, 661 (2d Cir. 1989) (Miner, J., concurring) ("I question whether judges, rather than literary critics, should decide whether literary material is used to enliven a text or demonstrate truth."). Litigants might, of course, proffer such expert opinion. Jury trials might he more effective than hench trials in assessing a work's worth to the public. In contrast, however, the Second Circuit did, at least implicitly, compare the relative merits of Ian Hamilton's prose and J.D. Salinger's. See Salinger v. Random House, Inc., 811 F.2d 90, 99 (2d Cir. 1987) ("To a large extent, [the quotes of Salinger's letters] make the book worth reading."). 
withhold it and for what reason; and (5) whether the author is alive at the time of the proposed use. ${ }^{82}$

These new factors refine "factor two" of the statutory test to differentiate the various concerns that a creator may have with respect to her unpublished expression: (a) for work intended for publication, an interest in preserving all the pecuniary value conferred by an exclusive right of first publication, including compensation for time and effort devoted to editing and revising the work; (b) a personal and pecuniary interest in withholding the work from view until such time as the author is willing to be identified as its author; (c) a personal interest in withholding from view expression that, by its form or content, might convey information that the creator prefers to suppress.

Factor (a) concerns the potential market impact of a preeinptive release of a work, or a significant part of a work. This factor fits easily within the statutory scheme: the analysis of the purpose of the use and its impact on the market for the original is the same for published materials. Factor (b), however, involves a complicated mix of pecuniary and personal interests. To the extent that a use preempts a creator's decision to release the work, the use may impair the market for the original by releasing an inferior version; such a use threatens the utilitarian scheine by reducing the potential rewards to an author who crafts a work with care. Such a use also threatens the creator's reputation, or even identity, by disseminating, as hers, expression that she has yet to coinplete. Although a utilitarian analysis does not readily account for why copyright should protect this interest, one could argue that a copyright scheme that permits users to preeinpt the creator on the timing and form of expression ultimately impairs the incentive to create by threatening creators' integrity and autonomy. Thus, although the threat inay be inore personal than pecuniary, the effect will be the same: deterring creation of expression. I argue below that protection of this "creative zone" is a legitimate part of the copyright scheine and that it would be beneficial for courts and scholars to define it carefully..$^{83}$

It is important to distingnish this "creative zone" interest from factor (c) where I believe copyright should play no part. The third interest is purely personal and judicial efforts to protect it under a statutory scheine designed to encourage dissemination by conferring proprietary rights will always generate convoluted rhetoric. The effort to protect what is loosely, and incorrectly, called privacy, within the copyright construct has had

82. See Crews, supra note 15 , at $68-90$, for a similar proposal allocating burdens of proof. Professor Crews does not address the likelihood that there will often be no credible evidence, apart from the copyright holder's affidavit, to establish the latter's intent with respect to publication or privacy.

83. See infra p. 443. 
undesirable effects on copyright doctrine. ${ }^{84}$ For one, the effort is at its core an effort to protect fact, not expression, and is thus wholly incompatible with copyright. The effort to protect facts by relying on copyright to protect the expression in which they are inevitably conveyed has so watered down the concept of a "work" as to lock all expression in a proprietary regime. For another, the attempt, in some cases, to equate copyright infringement with embarrassing revelation has clouded legitimate and fair scholarly

commentary with an aura of impropriety simply because the subject objects to being hoisted on his own petard.

It may often be that the use of expression not created for dissemination is unseemly and both intellectually and culturally undesirable. Nonetheless, copyright should not be enlisted simply because plaintiffs have found it easier to fashion a colorable claim under copyright than under other doctrinal categories, such as tort or contract. Those who truly wish to keep private expression private have means to do so by avoiding e-mail, by caring for their papers, and by instructing recipients to protect or even destroy correspondence. In such a case, a person offended by use of his letters might look to the recipient who sold the letters to a public archive before suing the biographer for infringement.

The copyright concern is whether a more liberal fair use doctrine would provoke more people to destroy their papers, ultimately destroying key resources for biographers and historians. This seems unlikely. Surely there are few people of any public renown oblivious to the fact that their papers may be of interest to biographers and others. ${ }^{85}$ Should they really wish to preserve privacy they could simply destroy their papers. I suspect that most people realize that their papers may be of some use, and perhaps they are even seduced into allowing access to private thoughts by the flattery of public interest. One might infer that a writer who knows that his papers are in an archive but who takes no steps to insist that the archive bar access is engaging in a sort of tease, tempting the future biographer to look but threatening reprisal if the biographer's portrait is not flattering. Thus, the current fair use doctrine as applied to unpublished materials allows abuse of the interests copyright is designed to serve. Creators can use copyright infringement actions to suppress unfavorable inforination by

84. See Leval, supra note 38, at 1125-30; see also Fisher, supra note 52, at 1171-72.

85. Their ranks, no doubt, include inany judges. Judges are professional writers who, as a class, may generate more "private" papers than the typical person and may, therefore, be particularly chary about the uses to which those papers might be put. An added irony is that judges may be particularly insensitive to the needs of historians and biographers to quote. Capable of compelling document production against a party's will, and blessed with a professional discipline that not only tolerates, but encourages, heavy quotation from earher writings that are generally within the public domain, judges may find it hard to relate to the private writer trying to establish an analysis with quotation from a recalcitrant subject. 
injunction, or they can use the threat of suit as a way to extract license fees for materials they never thought to publish themselves. ${ }^{86}$

II

\section{The Private Law of Fair Use}

One might argue that the effort to articulate better principles of fair use for the courts is not worth the effort, even if it were possible. ${ }^{87}$ Now that the 1992 amendment of section 107 has made it clear that fair use does extend to unpublislied materials, and the courts have responded with judgments that permit modest use for legitimate informational goals, ${ }^{88}$ one might conclude that some imperfection in judicial reasoning is tolerable. Indeed, one might even argue that a certain latitude or indeterminacy in the fair use "rules" allows liolders and users to make bargains that are more likely to achieve "fairness" than generalized rules in highly specific factual contexts. In addition, to the extent a writer may well be both holder and user of copyright at various times in his career, this indeterminacy arguably allows each writer to maximize his returns and minimize his costs by taking different stands on the scope of fair use depending on his position as holder or user at any given moment. This soothing model is fiawed in inodern trade publishing because it overlooks the role of the publishing company and standard trade publishing contracts in defining a private law of fair use and allocating risk of infringement. ${ }^{89}$

This Part describes current trade publishing contracts for biographical and historical works and deinonstrates that even a conservative reading of precedent would autliorize more use than industry practice now permits. Originating, apparently, as a reaction to the Salinger debacle, ${ }^{90}$ standard trade publishing contracts enforce a simple, but rigid, definition of fair use, based prinarily on word counts; the standard contract bans use of

86. Shifting some of the burden of proof to the plaintiff could prevent egregious abuses. See Crews, supra note 15.

87. See Weinreb, supra note 16, at 1160-61 (concluding that fair use doctrine "imparts to the copyright scheme a bounded normative element," and that "a standard of faimess calls for the exercise of great judicial skill. But it is not for that reason to be regretted.").

88. E.g., Norse v. Henry Holt \& Co., 991 F.2d 563 (9th Cir. 1993); Wright v. Warner Books, Inc., 953 F.2d 731 (2d Cir. 1991); Religious Tech. Ctr v. Lerma, 897 F. Supp. 260 (E.D. Va. 1995).

89. For evidence that trade publishers interpreted the Salinger opinion broadly to ban all use of unpublished materials, see infra note 90 . "Trade" publishers generally publish works of general interest, as opposed, for example, to acadeınic presses, which traditionally focus on scholarly monographs.

90. See, e.g., Paul Gray, The Man, but Not His Voice, TIME, June 27, 1988, at 59, available at 1988 WL 2599080 (reviewing ScotT Donaldson, John CheEver: A Biography (1988)). Gray quotes Gerald Hollingsworth, then Random House's chief legal counsel, as saying "As a result of the Salinger case, we paid an enormous amount of attention to the Cheever work. Whether we allowed Donaldson to use less of John Cheever's unpublished material than he would have liked is difficult to answer." Id. The review goes on to wish that more of Cheever's own words had been ineluded in the biography. Id. 
unpublished material. The relative bargaining power of individual writers and publishers makes negotiation of these clauses unlikely; the allocation of all risk of liability for infringement to the individual writer ensures that the trade definitions of fair use will seldom, if ever, be tested. While recent cases and legal scholarship convey the impression that fair use doctrine is in flux, as it may well be in other contexts, the private law of trade publishing has cemented definitions of fair use, mcluding a ban on use of unpublished material, that is essentially unreviewable. In this field, fair use has withered to a stalk. While a few scholars in law and the humanities continue to challenge the historical and philosophical underpinnings of the tendency to treat copyright as an increasingly broad entitlement, ${ }^{91}$ scholarly attention has largely turned to newer issues, such as international regulation of intellectual property, or the adaptation of intellectual property to new technologies. Yet, I argue that the quiet demise of fair use, at least of unpublished materials, in the old print industry, is worth studying as the copyright "coinunumity" considers whether market forces using private bargains will serve the public imterest in access to and use of digital databases. ${ }^{22}$

Scholarly and judicial discussions tend to treat fair use in terms of the interests of the holder, the user, and the public, ${ }^{93}$ and often conflate the interests of the creator and the holder of the copyright. ${ }^{94}$ The conflation

91. E.g., Peter Drahos, A PhIlosophy of Intellectual Property (1996); Martha Woodmansee, The Cultural Work of Copyright: Legislating Authorship in Britain, 1837-1842, in LAw IN THE Domains of Culture 65 (Austin Sarat \& Thomas R. Kearns eds., 1998); L. Ray Patterson, Folsom v. Marsh and lts Legacy, 5 J. INTELL. PROP. L. 431 (1998); Stewart E. Sterk, Rhetoric and Reality in Copyright Law, 94 Mrch. L. Rev. 1197 (1996); David W. Stowe, Just Do It: How to Beat the Copyright Racket, Lingua FRANCA, Nov.-Dec. 1995, at 32; Martha Woodmansee \& Peter Jaszi, The Law of Texts: Copyright in the Academy, 57 College ENGLISH 769 (1995).

92. See, e.g., Jessica Litman, Revising Copyright Law for the Information Age, 75 OR. L. REv. 19, 20 \& n.4 (1996) (criticizing the Clinton Administration's Information Infrastructure Task Force for engaging, in a 1995 report, in a "revisionist" history designed to camouflage a recommendation for expanding copyright holder's rights by arguing that current law already provides these rights).

93. See, e.g., Campbell v. Acuff-Rose Music, Inc., 510 U.S. 569, 572 (1994). The Court's assessment of the user's and holder's relative interests dominate the analysis. The concern for the public interest is subtler, implicit in the Court's acknowledgement that "[l]ike less ostensibly humorous forms of criticism, [parody] can provide social benefit, by shedding light on an earlier work." Id. at 579. For a more explicit analysis of the public's interest, see Harper \& Row Publishers, Inc. v. Nation Enterprises, 471 U.S. 539, 556-58 (1985) (finding that The Nation's "scoop" of a forthcoming presidential memoir was not justified by an asserted public interest in news).

94. In Harper \& Row, Justice O'Connor's opinion of the Court provides an interesting instance of the conflation. Although the opinion acknowledges Harper \& Row as the copyright holder, the Court's discussion uses Ford's role as author to bolster protection of Harper \& Row's interests. For example, the Court justifies particular protection against any copying before publication by reference to Ford's interests as author. The Court states that "[p]ublication of an author's expression before he has authorized its dissemination seriously imfringes the author's right to decide when and whether it will be made public," 471 U.S. at 551 , and points to "[t]he obvious benefit to author and public alike of assuring authors the leisure to develop their ideas," $i d$. at 555 . Both statements ignore the fact that Ford's memoirs were complete by the time of the alleged infringement and that he had authorized dissemination by transferring the right to publish to Harper \& Row. In fact, by the time of the alleged 
depends on the assumption that the transfer of rights from creator to holder is fairly bargained for and fully remunerated. The assumption of an equation of economic interests between publisher and author is plainly wrong; it overlooks the fact that the authors typically are compensated by an advance against a royalty account. In general, an author will not begin to receive royalties until the book is said to "earn out." Basically that occurs when the publisher has recouped the cost of acquiring and printing the book. Whether a book "earns out" and begins to generate royalties is, of course, uncertain and depends on many variables, including the publisher's marketing and distribution efforts. The author's total remuneration is contingent upon future sales minus costs, including liability. Even the assumption of equal bargaining is questionable in an era of increasing concentration in the industries that publish, distribute, and market copyrighted expression. It is doubtful that any but a few best-selling authors have the leverage to negotiate changes to standard contract terms. ${ }^{95}$

infringement, Ford had at best an indirect interest in his publisher's confidentiality or creative control. Having received an advance, he had only a finaneial interest in whether The Nation's "scoop" would adversely affect sales of the hardcover memoir sufficiently to reduce his future royalties. (Fisher points to some ambiguity in the trial record as to whether Ford's memoir was still subject to revision. There was no evidence supporting the assertion and no finding of fact on the issue. Fisher, supra note 52, at 1789-90. That revisions were still possible a few weeks before distribution strikes me as a canard, as does the plaintiff's effort to invoke concern for the creative process even though it was, in fact completed.).

Landes and Posner acknowledge the costs of such a conflation:

To simplify [their economic analysis of copyright law] we ignore any distinction between costs incurred by authors and by publishers, and therefore use the term "author" (or "creator") to mean both author and publisher. In doing this we elide a number of interesting questions involving the relation between author and publisher. For exainple, do such principles as droit moral, entitling authors to reclaim copyright from assiguees after a fixed period of years ... increase or reduce the incentive to create new works? The answer suggested by economic analysis is that, contrary to intuition, such principles reduce the incentive to create by preventing the author ... from shifting risk to the publisher .... A publisher (say) who must share any future speculative gains with the author will pay the author less for the work, so the risky component of the author's expected remuneration will increase relative to the certain component. If the author is risk averse, he will be worse off as a result. However, we do not explore such matters in this article.

Landes \& Posner, supra note 74, at 327 . With respect to the risk of liability for infringement, economic analysis coalesces with intuition. Under the publishing contract the author bears almost all of the risk of liability, including the risks that the publisher will refuse to publish his work and insist on a return of the advance should the author insist on a broader interpretation of fair use than the publisher's. In theory, the publisher might be willing to pay the author more in certain remuneration because the publisher does not bear the risk of liability for infringement; this would be true if the contract merely allocated risk; in fact, however, the provisions essentially eliminate the risk, not just of a finding of infringement but even of the possibility that a holder might challenge the use, by constricting fair use to a narrower scope than any court has to date. The confiation of ereator and publisher interests, by the publisher, has a long history. Cf. Woodmansee, supra note 91, at 67 (arguing that the stationers in 17th century London promoted their own interest in deterring competitive copiers outside London by couching their arguments for the "copyright" afforded by the Statute of Anne in the guise of the writer's entitlement to reward for his labors).

95. See Stephen Breyer, The Uneasy Case for Copyright: A Study of Copyright in Books, Photocopies, and Computer Programs, 84 HARV. L. REv. 281 (1970). The author notes the probable effect of concentration in the publishing industry: 
This Article depends in part on the premise that most writers lack the leverage (and often the desire) to negotiate changes to the standard terms governing permissions and fair use in publishing contracts. ${ }^{96}$ Standard terms generally confine fair use to a significantly narrower scope, particularly in the use of unpublished material, than even a conservative analysis of current case law would require. The tendency to conflate author and holder camouflages the fact that they may have very divergent interests in the scope of fair use. To the serious biographer, historian, or other writer, the scope of fair use can have an important impact on the quality of a writer's work and how much it costs him to create it. To date no one has examined whether this "private law" of fair use, largely dictated by publishers, serves the public interest by providing the right balance of incentives to "old" and "new" authors. The following analysis focuses on the economic effects of contractual risk allocation but also touches upon the question of whether the private law einbodies presumptions about the intellectual, aesthetic interests or "authors' rights" of the "old" creators and the "new" creator-user of copyrighted expression. The latter's personal interests, if any, are largely ignored in fair use analyses of the "authors' rights" of the creator of the "used" expression."

\title{
A. Risk Allocation: Burden on the Writers
}

Standard trade publishing contracts and in-house "fair use" guidelines are mucli more restrictive of fair use than even the most restrictive judicial interpretations. $^{98}$ Equally important, the standard trade contract ${ }^{99}$ has

\begin{abstract}
Although a copyright restricts competition only between copies of the same title and does not legally interfere with competition between titles, the power to accumulate these exclusive licenses to publisl may nonetheless, at least in theory, inhibit such competition. This power may, for example, allow a few publishers to build "stables" of popular writers. The presence of sucl a "stable" may strongly attract other writers with valuable manuscripts and make it more difficult for a newcomer to obtain the promising manuscripts necessary to become established in the publishing industry. If, as a result, new entry becomes difficult, wellestablished publisbers may find that they have obtained the power to raise their prices and to resist authors' demands for higher royalties. Any sucb power can curtail book circulation (by raising prices) and may even limit the number of titles produced (by restricting royalties).
\end{abstract}

Id. at 318-19 (footnote omitted). Breyer's concerns about industry concentration have come true in the book-publishing industry. See Doreen Carvajal, Book Publishers Seek Global Reach and Grand Scale, N.Y. TmEs, Oct. 19, 1998, at Cl; Daniel Johnson, Springtime for Bertelsmann, NEw YoRKER, Apr. 27May 4, 1998, at 104. It remaims to be seen whether "self-publishing" efforts, made possible by the Internet, will provide viable avenues for writers to reach readers without publishers.

96. Breyer, supra note 95, at 320. See also infra note 111 .

97. But see Gordon, supra note 52, at 1032-40 (discussing Harold Bloom's theory that new writers may need to engage in "creative misprision" of older author's work and noting that such "hostile use" is precisely the use in need of the fair use doctrine because the older author is most unlikely to grant permission).

98. See, e.g., Random House, Inc., Text Permissions (undated) (unpublished in-house guidelines, on file with author). The mimeograph provided to authors provides in part:

What requires permission? 
several provisions that substantially inhibit any writer from testing the limits of fair use by imposing essentially all of the risk for an infringement upon the writer. ${ }^{100}$ Specifically, the contracts provide that the writer must warrant that the "Literary Work does not infringe any statutory or common

I Any direct quote previously published after 1920 [sic] that is over 250 words. Written permission must be obtained from either the publisher or the source which currently controls the rights.

$\mathrm{J}$ A personal letter. Permission must be obtained from the person who wrote the letter, no matter who may currently own the actual, tangible letter. If the person is deceased, permission should be pursued through the source which controls the writer's estate. No matter how innocuous the contents of a personal letter may seem, pursue the permission.

...

P Extensive paraphrasing from another work. (Contact us if you are unsure.)

$\mathrm{V}$ Small quotations from another work (nnder 250 words) should be weighted against the percentage of the work they represent. In other words, a 50 word quote represents a more substantial chunk of a 30 page work than of a 1,200 page work. If any doubt as to whether a small quotation should have a release, contact us.

Id. Other publishing houses have similarly restrictive views of fair use of unpublished materials. As an cditor for Simon \& Schuster responded to a query regarding Simon \& Schuster's fair use rules on quotation of unpublished materials:

No written guidelines, unfortunately.

There is only a rough rule of thumb, and anytime you have any doubt, you should assume you need permission. The ONLY thing that has ever blocked publication of a book is a copyright violation (the Salinger bio).

There is fair use for purposes such as yours (a literary biography). How much you can use depends on the length of the publication from which you're quoting. If it's a full length book, 500 words is almost always $\mathrm{OK}$, possibly more if it's a long book. If it's a magazine article, a paragraph is probably $\mathrm{OK}$, assuming normal length. If it's a letter, it might be a sentence, maybe more, maybe less, depending on length. A poem, anywhere from nothing to several lines, depending on length.

As mentioned, there is NO fair use of unpublished materials. (That's what blocked the Salinger bio; unpublished letters were quoted.)

All of this is cumulative throughout the book. If you quote from an essay in three different chapters, you have to total all the quotations.

If you are less than certain about any quotatious, let me know what they are, with page references and as much detail as possible, when you turn in the manuscript and I will have the lawyer rcad and reply.

E-mail from Robert Bender, Editor, Simon \& Schuster, to David Laskin, author (Nov. 13, I998, 14:47:43 EST) [hereinafter Bender E-mail] (on file with author) (emphasis added).

99. The terms of other trade and university press publishing contracts are substantially similar in effect. They inpose upon the author the duty to warrant that the work under contract is original and does not infringe any copyright or privacy interest of any person. The publisher also has the right to defend against an infringement action. The author must pay for his own attomey and, subject to various insurance deductible amounts, the author is liable for at least half of all of the costs associated with an infringement action. See, e.g., Ballantine Books et al., Agreement (Nov. 21, I989) (unpublished sample book contract, on file with author); Sasquatch Books et al., Agreement (May 6, 1999) (unpublished sample book contract, on file with author); Doubleday et al., Agreement (July I7, 1992) (unpublished sample book contract, on file with author); Ietter from University of Washington Press, (undated) (unpublished standard book contract, on file with author).

I00. For example, a Simon \& Schuster, Inc. sample contract provides a number of restrictive terms on the writer. Simon \& Schuster, Inc. \& David Laskin, Publishing Agreement (Mar. I6, 1995) [hereinafter Simon \& Schuster contract] (unpublished contract, on file with author). Portions of this contract are reproduced in the Appendix. The terms of the contract quoted in the Article were and remain standard. Telephone Interview with Lisa Rivlin, Counsel, Simon \& Schuster, Inc. (July 8, 1999). 
law copyright or any proprietary right of any third party."101 The writer must also warrant that the work "does not invade the right of privacy of any third person."102 The publisher has absolute discretion to require the writer to secure permissions and to determine the fairness of a proposed quote. $^{103}$ The pubhisher may refuse to pubhish the manuscript and may recoup any advances paid the writer if in the pubhsher's "sole and absolute judgment, whether before or after acceptance thereof, the Literary Work contains libelous or obscene material, or its publication would violate the right of privacy, common law or statutory copyright, or any other right of any person." 104 The author

indemnifies and holds the Pubhisher harmless against any loss, liability, damage, cost or expense (including reasonable attorneys' fees) arising out of or for the purpose of avoiding any suit, proceeding, claim or demand or the settlement thereof, which may be brought or made against the Pubhsher by reason of the publication, sale, or distribution of . . . the Literary Work. ${ }^{105}$

The contract purports to limit liability, providing that the author "shall be insured under the Publisher's hability policy which covers claims for... infringement of copyright... arising from publication of the Literary Work, to the extent such pohicy is valid and collectible."106 The pohicy has a $\$ 100,000$ deductible. The contract provides that the author and pubhsher shall share equally the first $\$ 100,000$ of costs; after that the author's liability is limited to $10 \%$ of costs up to the limit of the pohcy. ${ }^{107}$ This limitation on the author's hability does not appear, however, to extend to a failed fair use defense. ${ }^{108}$

Only a highly notivated and wealthy writer would dare test the boundaries of fair use under such a contract or could probably afford to purchase her own insurance. Confronted by an author who insists on a use the publisher does not approve, the publisher has many options and little risk. The publisher has absolute discretion to determine fair use, and the writer is obligated to make any changes that the publisher's lawyer deems

\footnotetext{
101. Simon \& Schuster contract, supra note 100, at para. 39.

102. Id. at para. 40 .

103. Id. at para. 41 (c).

104. Id. at para. 83(a).

105. Id. at para. 87(a).

106. Id. at para. 90 .

107. Id.

108. The clause provides:

Notwithstanding the foregoing, Author shall be solely responsible for the cost of counsel separately retained by the Author for any reason and for judgments, settlements and costs of defense, including all attomeys' fees, attributable to a willful or reckless breach of this agreement by the Author, and for any uninsured amount upon the finding of any copyright infringement.
}

Id. 
necessary in the latter's "reasonable judgment."109 "Reasonable judgment," moreover, is not limited to a lawyer's reasonable assessment of the public law; it could also include any reasonable assessment of the publisher's commercial interests. If the writer insists that a use is fair, the publisher may simply cancel the book and recoup any advance.

If the book is published, regardless of the publisher's ignorance, indifference, or acceptance of the use, the author faces three risks should the copyright holder bring an infringement claim. First, the publisher could take the position that the use was a willful or reckless breach of the contract; in that case, the author is solely responsible for all costs. Second, if a court upholds the infringement action, the contract removes the cap on exposure so that the writer will be solely liable for all damages and costs incurred by the publisher and by herself. Third, even if vindicated in court, the author may face $\$ 50,000$ or more uninsured costs under the deductible, a substantial sum for all but a few best-selling writers. For example, Ian Hamilton, a well-established biographer, earned a $\$ 100,000$ advance for the American print of the ill-fated Salinger biography. ${ }^{110}$ Most biographers and historians command less. ${ }^{111}$

\section{B. Risk Aversion: Financial Incentives of the Publishers}

This private ordering ensures that fair use issues may rise to public, or judicial, scrutiny only where the publisher has a financial incentive in permitting an author to use material, a motivation which in itself tends to weigh against the fairness of the use. ${ }^{112}$ Conversely, where the publisher perceives little benefit to itself from the use and any risk that the copyright holder may object to the use, either for financial or personal reasons, the publisher has little incentive to permit the use. Unless a publisher can predict an increase in revenue attributable to the use that exceeds the risks associated with an infringement action, or the cost of securing permission, if available, a rational publisher will not permit the use. The reality, then, is that most publishers have no incentive to permit uses that even approach the limits suggested by current case law. The modest use of quotes to prove

109. Id. at para. 83(a).

110. Frederick M. Winship, Ian Hamilton's Losing Match With J.D. Salinger, UPI, June 24, 1988, LEXIS, available at News Library, UPI File.

111. The most specific data on writers' average advances comes from THE AMERICAN ALMANAC OF JOBS AND SALARIES, 2000-2001, at 555-57 (John W. Wright ed., 2000) (noting about advances that "[a] very good project rarely brings over $\$ 75,000$ " and that "most first novels and serious nonfiction books bring advances of $\$ 7,500$ to $\$ 25,000$ "). Certain celebrities and established writers can command advances into the millions. Id. at 557.

112. See, e.g,, Harper \& Row, Publishers, Inc. v. Nation Enters., 471 U.S. 539, 563 (1985) (“fair use" distinguishes between the scholar and a chiseler who infringes a work for personal profit); Salinger v. Random House, Inc., 811 F.2d 90, 99 (2d Cir. 1987) (the quotes made the book "worth reading"); Lish v. Harper's Magazine Found., 807 F. Supp. 1090 (S.D.N.Y. 1992) (holding that the copying without any comment was designed to sell magazines due to the copyright holder's notoriety). 
a fact and illustrate a thesis may enhance the intellectual and aesthetic caliber of a work, but, unless eye-popping in their revelations, they are unlikely to enhance sales in any measurable degree. ${ }^{113}$ The Salinger case affords a good example. The Second Circuit objected, in part, to Ian Hamilton's use of Salinger's letters because they enlivened the text. Although the court purported to find the enlivening effect in the quality of Salinger's prose, one suspects that Hamilton and Random House were at least equally inotivated by their perception of a substantial market for the letters of a famous recluse. ${ }^{114}$ Of course, there could be no copyright in facts revealed by the letters. By focusing on the "enlivening" quahity of the prose, the Salinger opinion avoided the issue that bedevils all biographies of hiterary figures: how to distinguish fact from expression where the fact is not only imbedded in arguably original expression but inay in fact be synonymous with the expression.

Aversion to risk may not be the only reason publishers deter uses. At least one commentator has noted that holders of substantial copyright interests liave an incentive to narrow the scope of fair use, establisli a custoin of requiring permission for rights owned, earn revenue, and create a measure of market impact slionld they wish to challenge unlicensed uses of materials for whicl they hold the copyright. ${ }^{115}$ Publishers have a comparable incentive to encourage fair use of materials whose rights they do not own. One may guess that, in general, the rights to unpublished works are retained by their creators and their estates and are not transferred to major publishers. If sucli materials may be used witliout payment, then presumably publisliers could pay their authors less. But it may well be that this financial benefit is very small coinpared to the potential revenues from narrowing the scope of fair use and establishing an industry practice for the

113. This analysis raises a disturbing prospect: even if the courts were to improve their analyses, private industry practices might persist. The interplay of public and private law in this context deserves empirical analysis beyond the scope of this Article. Tentatively, however, one suspects that increased determinacy in the rules, and more explicit respect for the needs of scholars and biograplers to document their analyses, would at least increase the odds that determined scholars, or establislied biographers, could challenge mdustry practice. Such improvements might also imcrease the odds that a "test" case presenting facts more favorable to the user than those of either of the seminal cases, Harper $\&$ Row or Salinger, might be brought. Such a test case would help change the "culture" of publishing away from a knee-jerk presumption against quotation of unpublished material. While this Article depicts publishing companies' operating motives as principally commercial and therefore not promptly or dramatically responsive to a cultural shift, it is possible that a culture shift would affect decision making at the individual editorial level.

114. Salinger, 811 F.2d at 98-99.

115. Lydia Pallas Loren, Redefining the Market Failure Approach to Fair Use in an Era of Copyright Permissions Systems, 5 J. InTEll. Prop. L. 1, 6 (1997) (citing Princeton Univ. Press v. Mich. Document Servs., Inc., 99 F.3d 1381 (6th Cir. 1996) (en banc)). 
payment of license fees for all the copyrights that the publisher does own. ${ }^{116}$

The problem with insulating the publishers' private interpretation of fair use from public scrutiny is that it provides little opportunity to assess whether the market for works, as perceived by publishers, adequately serves the public interest in stimulating creation of and access to works. ${ }^{117}$ The market probably cannot protect the public interest completely because the consumers generally lack the information to create a market for subtle improvement in the number and quality of works. This is particularly so if one focuses on quality, not merely quantity, of works created. It is difficult to measure, by any objective standard, the marginal increase in the quality of a work attributable to the use of relatively small amounts of copyrighted material, that is, the type of use that might be fair. It is equally difficult to measure the market impact of increased quality because there will rarely be good market substitutes for a particular book. Absent the availability of two books on virtually the same topic, the reading public cannot discern whether one work is better, fairer, more accurate, incisive, educational, and susceptible to reasoned analysis, because it includes quotations that are not included in the comparison book. ${ }^{118}$

As a result, there probably is no market mechamism to support modest qualitative improvements in works. A biographer or historian probably cannot determine the marginal impact, if any, on sales of a given use of copyrighted material. Although the writer may feel quite strongly on intellectual or aesthetic grounds that his work would be more accurate, probative, or interesting, the writer is unlikely to be able to convince a

116. Financial data would be interesting if it could be obtained. For example, one could compare the amounts various publishers pay for insurance and litigation with the amounts they receive in permission fees.

117. See Wendy J. Gordon, Fair Use as Market Failure: A Structural and Economic Analysis of the Betamax Case and Its Predecessors, 82 Colum. L. REv. 1600, 1626-27 (1982) (analyzing previous decisions by relying on the premise that markets generally serve the public imterest in access most efficiently, and concluding that courts tend to rely on the market in finding fair use by a defendant only where evidence suggests that the market forces are not "trustworthy").

118. An interesting empirical study might attempt to measure the unlicensed use of quotations in "comparable" works of non-fiction written before and after the Salinger decision. It might be relevant to compare the relative rate of quotation in a scholarly monograph and a trade book on a given biographical topic. Although one might hope that university presses would be more inclined to permit relatively liberal fair use in the interest of scholarly discourse, anecdotal mformation suggests that university presses employ the same strict definitions of fair use as trade publishers. Moreover, desperate to compete with media conglomerates, university presses are no more likely than any other publisher to permit free or low cost use of copyrights they own; indeed university presses increasingly struggle to publish the scholarly works that were their mainstay. Now, to stay afloat financially, many are turning to more commercial books over scholarly monographs. At most, one editor told me that authors may be able to negotiate relatively low permission fees with certain holders if they can essentially plead poverty, by pointing to a relatively small advance for a book unlikely to sell many copies. Telephone interview with Naomi Paschal, Editor, University of Washimgton Press (Aug. 11, 1999). 
publisher to pay him a bigger advance (or, provide a bigger permissions budget) in order to license the use ${ }^{119}$ and, as discussed above, the publisher's contract deters the writer from making any use of unpublished material. Faced with this situation, a writer will excise a quotation that he would otherwise find illustrative or probative of a thesis because the publisher does not deein the use fair and will not underwrite the licensing fee, if permission is even available.

The trade publisher interpretation of fair use raises the "cost of expression" ${ }^{\prime 120}$ for the writer. Arguably, the writer will only incur this cost if he has a compensating incentive, presumably financial, though possibly intellectual or aesthetic. Private law bars the use of unpublished expression that might have intellectual or aesthetic merit but that lacks quantifiable market value. It does so more rigorously than case law now mandates; because of the financial interest of publishers and the contractual liability of authors, the private law is unlikely to respond to, or reflect, modest liberalization of public fair use doctrine. The publishers have too little incentive, and the authors have too much risk, to challenge existing practice. As a result, only those uses that have measurable financial benefit to publishers are likely to break through the private restraints against use; ironically, those are precisely the uses most likely to threaten the market for the original expression or the non-pecuniary interests, such as privacy, of the creator.

119. See Breyer, supra note 95 (noting that concentration in the publishing industry enables publishers to resist most writers' demands).

120. See Landes \& Posner, supra note 74, at 327 (explaining that the cost of creating a work, or the "cost of expression," "consists primarily of the author's time and effort plus the cost to the publisher of soliciting and editing the manuscript and setting it in type"). Significantly, the authors also note that

[b]eyond some level copyright protection may actually be counterproductive by raising the cost of expression.... Creating a new work typically involves borrowing or building on material from a prior body of works, as well as adding original expression to it. ... The less extensive copyright protection is, the more an author ... can borrow from previous works without infringing copyright and the lower, therefore, the costs of creating a new work. Of course, even if copyright protection effectively prevented all unauthorized copying from a copyrighted work, authors would still copy. But they would copy works whose copyright protection had run out, or they would disguise their copying, engage in costly searches to avoid copying protected works, or incur licensing and other transaction costs to obtain permission to copy such works. The effect would be to raise the cost of creating new worksthe cost of expression, broadly defined-and thus paradoxically, perhaps lower the number of works created.

Id. at 332. The authors' point supports mine, although they focus not on the quality of works created but only on the quantity. The private law effectively raises the author's cost of expression. Whether a given author receives remuneration sufficient to cover the cost is unclear. 


\section{Market Failure of Private Fair Use Law}

Much of the most influential recent scholarship on copyright is grounded in law and economics. ${ }^{121}$ Using an economic analysis, one might argue that the increased "cost of expression" generated by any particular use should not concern us, that given a large sample over an extended period, the private law's impact on the creation of new works is neutral. It is now commonplace to observe the cyclical use of expression; writers use earlier expression to create new expression that is, $m$ turn, used to generate expression, and so forth. ${ }^{122}$ If true, this suggests that, in the aggregate, the economic impact on writers of any given construction of fair use, whether narrow or broad, would be a wash. Thus a narrow construction would raise writers' costs of expression and incentives to create; a broad construction would lower both. Thus, if fair use is narrowly construed, writers as a group could expect to incur higher costs of expression; by the same token, writers could expect to earn more incoine from license fees. Similarly, if fair use is liberally construed, writers as a group could expect lower costs of expression but also lower license fees. At least im theory, over a large sample, the financial incentive to create would be comparable under either construction and thus the public interest in access to new works would be served equally well by either regime.

This analysis is consistent with the "market failure" theory of fair use: that is, that the open market is generally the most efficient mechanism for trading copyright interests and is thus the best system for ensuring public access to works. An unpaid-for use (or a mandatory license) is appropriate ("fair" or "in the public interest") only where the market "fails," as where excessive transaction costs, externalities that cannot be internalized in the license, or interests such as privacy, interfere with an efficient market for licenses. ${ }^{123}$ The market-failure theory has provided an elegant rationale for relatively extensive fair use for parody or for hostile criticism because of the holder's presumed hostility to licensing. ${ }^{124} \mathrm{By}$ analogy, the market-failure theory would validate fair use of unpublished

121. E.g., Fisher, supra note 52; Gordon, supra note 52; Landes \& Posner, supra note 74; Loren, supra note 115.

122. See, e.g., Gordon, supra note 52 , at 1030 (discussing a theory espoused by literary critics, including Harold Bloom and Terry Eagleton, that all literary works are derivative of predecessor works in "misreading" or at least reacting to what has gone before); see also HAROLD BLOOM, THE ANXIETY of Influence: A Theory of Poetry 5 (2d ed. 1997); Terry Eagleton, Literary Theory: An INTRODUCTION 183 (2d. ed. 1996).

123. See Gordon, supra note 52, at 1627-30; Loren, supra note 115, at 5-6.

124. See, e.g., Campbell v. Acuff-Rose Music, Inc., 510 U.S. 569, 591-92 (1994) (noting that scathing parody might destroy the market for a work but it will not likely affect the market for the original by acting as a substitute); see also PAul Goldstein, 2 Copyright PRINCIPLEs, LAw AND PRACTICE 191-92 (1989) (arguing that copyright protection should generally extend only to holders seeking monetary exploitation of the work, while observing that privacy interests might receive some deference in unpublished works); Gordon, supra note 52, at 1041. 
material where, for example, the transaction costs of securing permission exceed the combined value of the rights to the user and the holder or where the holder would refuse to license at any price.

At first blush, one might conclude that this theory is sufficient to resolve disputes over the use of unpublished writing. But it is not. Market analysis falters where the owner of an asset has not injected that asset into the marketplace by publishing the work or otherwise transferring ownership interests. An author who refuses to license the use of an unpubhished work can imvoke cultural and constitutional ideals of privacy, autonomy, and the right to remam silent, but the author who refuses to license a published work to a parodist or critic threatens the cultural and constitutional ideals of free speech. The market-failure theory effectively trumps the second author's claim because the theory is an overt constituent of a "marketplace of ideas" ideology; by publishing the work, the second author, perhaps unwittingly, accepts that ideology by injecting his work (or ideas) into that marketplace. Having joined the "madding crowd" he cannot then complain at being jostled. However, this economic, utilitarian theory provides no persuasive resolution for disputes concerning the appropriate use of unpublished writings where the copyright holder has not "entered" the marketplace and argues (more or less overtly) that he is protecting his person, not his ideas, from public view. ${ }^{125}$

Even with respect to the use of published materials, the literature on "market failure" has not analyzed the "three-way" transactions ainong copyright holders, users and publishers discussed above. For exainple, the idea that costs and incentives to writers even out over a large sample assumes a comparable present value between permission fees. Even if comparable, fee requirements would tend at any given time to favor older copyright holders (whether creators or publishers) at the expense of new creators. Essentially a new creator must spend cash in the hope that she may one day earn a compensating benefit. At any given moment, the need to pay for use pits a present expense against an uncertain future royalty. When a publisher contractually imposes upon an author a duty to secure permission the publisher raises the author's cost of expression. If the subject of permission is unpublished, the publisher has then mcreased the return to that writer even though, in many cases, the unpublished writing was written without thought of remuneration. If the work is published, the writer of the used material will only receive a benefit if she has "earned"

125. See, e.g., Wright v. Warner Books, Inc., 953 F.2d 731 (2d Cir. 1991) (protecting a widow's interest in privacy of writer's journals); Salinger v. Randoin House, Inc., 811 F.2d 90 (2d Cir. 1987) (protecting privacy and reputation); Meeropol v. Nizer, 560 F.2d 1061 (2d Cir. 1977) (protecting the Rosenberg children's desire for privacy); Lish v. Harper's Magazine Found., 607 F. Supp 1090 (S.D.N.Y. 1992) (protecting a famed writing teacher's confidential letter to students). 
out her advance; otherwise, the permission fee simply increases her publisher's revenues. ${ }^{126}$

Publishing contracts effectively subsidize a substantial subset of unpublished expression without regard to whether the expression would have been created regardless of financial incentives. Thus, private rules barring or narrowly circumscribing use of unpublished expressions encourage rentseeking if the expression is deemed copyrighted and not subject to fair use. Further, publishing contracts do not require any scrutiny of whether a use will actually damage non-pecuniary interests of the author of unpublished writings. Thus, without any specific application of utilitarian principles, or the "authors' rights" theory, these contracts raise the cost of expression to new writers and deter those writers from quoting material that might otherwise be useful to the reading public. Quotation of texts enhances the reader's ability to evaluate the second author's analysis, whether that analysis concerns the style or meaning of the text itself, or concerns the interpretation of events or character.

Despite the 1992 amendinent to the Copyright Act reaffirming the application of the fair use doctrine to unpublished materials, ${ }^{127}$ and despite the Second, ${ }^{128}$ Fourth, ${ }^{129}$ and Ninth ${ }^{130}$ Circuits' willingness to permit some use of unpublished material, publishers have not expanded their in-house gnidelines for fair use. ${ }^{131}$ They have little incentive to do so.

To revive fair use of unpublished material in private law, at least two things must happen. First, courts need to articulate and apply more honestly and completely their actual criteria for deciding what is fair. This may not render the doctrine of fair use, per se, inore precise or determinate than it is now. In fact, I suspect that such honesty would reveal that the four-factor analysis of section 107 is of little use when significant non-pecuniary interests are at stake. Nevertheless, if the applicable principles, whatever they are, were at least patent, a highly inotivated writer might with soine assurance determine what uses would be fair and might, without too much risk, resist the blanket claims of publisher and copyright holder that just about every quote needs permission.

Second, those who agree that current private trade defimitions of fair use have over-extended copyright to the detriment of the public good in well-documented, quality works of history, biography, political and cultural commentary need to act. In particular, they will need to educate

126. Ken Auletta, The Impossible Business, NEw Yorker, Oct. 6, 1997, at 50 (noting how few authors "earn out" the advance on their royalty accounts).

127. Pub. L. 102-492, 106 Stat. 3145 (codified at 17 U.S.C. $\S 107$ (1994)); see supra note 51 and accompanying text.

128. Wright, 953 F.2d 731.

129. Sundeman v. Seajay Soc'y, Inc., 142 F.3d 194 (4th Cir. 1998).

130. Norse v. Henry Holt \& Co., 991 F.2d 563 (9th Cir. 1993).

131. See, e.g., Bender E-mail, supra note 98. 
and advocate to counter the widespread assumption among writers that "more" copyright necessarily benefits them. ${ }^{132}$ To escape the categories of section 107 is to foster a needed discussion of the appropriate boundaries between exploitable expressive work and mviolate personal integrity. Under what circumstances one may use another's words to reveal something that the other prefers to leave unrevealed remains present and unresolved since Salinger. If a future court is presented with an appropriate controversy, perhaps it will rise to the challenge of confronting this difficult issue expressly.

\section{III}

\section{THE RHETORIC OF SECTION 107, HARPER \& ROW, AND SALINGER}

In this Part, I argue that close textual analysis of syntax, word choice and paragraph structure in the seminal cases reveals that the actual determinants of fair use of unpublished materials are not what the courts say they are. While the courts consistently claim that statutory copyright protects only pecuniary interests im exploiting works, the courts have consistently bolstered questionable judgments with rhetoric about authors' autonomy, integrity and privacy. The results are contradictory holdings that present a baffling paradox: Under current law, minimal quotes from a memoir presenting a public figure's pedestrian descriptions of events and his personal reactions to them are likely to be infringenents, ${ }^{133}$ while wholesale duplication of a draft manuscript and its substantial quotation im a scholarly paper and talk are not. ${ }^{134}$

It is convenient to explain away the apparent paradox by pointing to two distinctions in the generating cases. First, The Nation's quotes from Ford's memoir had a proven impact on the market for a derivative of the original work, ${ }^{135}$ while there was no such evidence concerning the use of Rawling's manuscript. ${ }^{136}$ Second, the memoir was technically a work-improgress, theoretically still subject to revision; im contrast, the manuscript was in its final form. However, just the opposite is true. The memoir had been completed and edited and was only a few weeks away from distribution; ${ }^{137}$ the manuscript, on the other hand, was unpolished juvenilia that the author lad apparently abandoned. ${ }^{138}$ If, as the Supreme Court

132. See, e.g., National Writers' Union, Contract Issues: Books Published Online, at http://www.nwu.org/book/online-p.htm (last visited Oct. 28, 2000) (advocating that online book authors should have a copyright in materials hyperlinked to their work).

133. Harper \& Row, Publishers, Inc. v. Nation Enters., 471 U.S. 539, 569 (1985) (involving The Nation's quotation of former President Ford's soon-to-be-published memoir).

134. Sundeman, 142 F.3d 194 (involving a scholar's quotation, both orally and in an unpublished article, from an unpublished novel by Marjorie Rawlings).

135. Harper \& Row, 471 U.S. at 567.

136. Sundeman, 142 F.3d at 206-07.

137. Harper \& Row, 471 U.S. at 542-43.

138. Sundeman, 142 F.3d at 197-98. 
claims, an author's right to creative control over the final published form of expression should strictly limit pre-publication "fair use," arguably the second author's implicit decision not to release the manuscript should have been a weighty factor against the fairness of the use so long as the copyright term endured.

An equally important distinction is that in Harper \& Row the author, Ford, was alive and in Sundeman, Rawlings was dead; the two cases may be better reconciled by understanding the courts' unacknowledged deference to a living author's nonproprietary interests in how and when his words are used. In particular, the Supreme Court inflated its rhetoric concerning a living author's need for creative control over his individual expression to divert attention from a fairly strong defense based on the First Amendment and fair use. ${ }^{139}$ While the Court wisely avoided "constitutionalizing" its judgment by confining the analysis to the Copyright Act, its reluctance to deny expressly the First Amendment defense may have contributed to its desire to bolster the judgment by inflating the defendant's shabby commercial behavior into an affront to individual self-expression.

In the short term, the doctrinal impact on fair use was devastating. Despite criticism and subsequent efforts to limit the case to its facts, the rhetorical deference to individual control of expression has outlived both the majority's agenda at the time and subsequent criticism of the case. The rhetoric has rendered meaningless the conferral of statutory copyright to "works of authorship." At least for the living, any written "personal" expression, no unatter how mundane, unpolished and slight, will be deemed original, and thus copyrighted, if it embodies any perception, einotion or attitude of the expressor. Since it is difficult to imagime how any expression could avoid doing so, the rhetoric has succeeded in doing just what the courts deny doing: protecting aspects of personal identity and privacy through copyright. As a practical result, so long as the writer is alive, any squib of unpublished expression may be copyrighted and nearly immunized from fair use. At best, this is a de facto expansion of the statute's coverage from "works" to "expression." At worst, it confers the privilege of censorship upon an expressor to limit any careful, documented analysis of his perceptions, emotions, or attitudes at least for his lifetime, and perhaps for seventy years thereafter.

\section{A. The Incoherence of Fair Use Law: Section 107 of the 1976 Copyright Act}

Before the courts' treatnent of the 1976 Act, Congress had already indulged in soine opaque legislative terminology that anticipated the

139. Harper \& Row, 471 U.S. at 560. 
courts' tendency to conflate the right to exploit a proprietary asset with interests in personal identity, autonomy, and privacy. Professor Jessica Litman has cogently summarized the interest group bargaining and compromises that eventually resulted in enactment of the 1976 Act. $^{140}$ The section on fair use is a notable example. By its terms, section 107 provides that "the fair use of a copyrighted work ... is not an infringement of copyright."141 Despite an obvious statutory argument that this language creates an exception to a holder's exclusive rights and assigns to the plamtiff the burden to establish an infringeinent, ${ }^{142}$ the courts have consistently characterized fair use as a defense. ${ }^{143}$ The Supreme Court recently held that the defendant, at least in the context of a defense motion for summary judgment, had the burden of "demonstrating fair use."144 In addition, the argument could be made, although it has not been yet, that deference should be paid to the statutory interpretation of the person who must mitially interpret the statute. ${ }^{145}$ The statutory scheme assumes that the initial imterpretation will be made by the copier.

The use of "subsist" in the basic conferral of copyright is another example of artful avoidance of resolving an old debate between a utihtarian and authors' rights interpretation of the copyright. Section 102 provides in part: "[C]opyright protection subsists ... in origmal works of

140. Litman, supra note 15, at 860-61. Professor Litman writes:

[T] he statute's legislative history is troubling because it reveals that most of the statutory language was not drafted by members of Congress or their staffs at all. Instead, the language evolved through a process of negotiation among authors, publishers, and other parties with economic interests in the property rights the statute defines. In some cases, affected parties agreed upon language, which was then adopted by Congress, while disagreeing about what the language ineant.

Id. (footnote omitted).

141. 17 U.S.C. $\$ 107$ (1994).

142. Patterson, supra uote 91, at 451. Professor Patterson's article presents a useful historical analysis of the expansion of statutory copyright and the simultaneous contraction of fair use, particularly for consumptive rather than competitive uses.

143. E.g., Campbell v. Acuff-Rose Music, Inc., 510 U.S. 569, 590 (1994) (noting that fair use is an "affirmative defense" and that the defendant would have the burden of "deinonstrating fair use" (citing Harper \& Row, 471 U.S. at 561; H.R. Rep. No. 102-836, at 3 n.3 (1992))); see also Harper \& Row, 471 U.S. at 549; Salinger v. Random House, Inc., 811 F.2d 90, 95 (2d Cir. 1987). But see Sundeman, 142 F.3d at 201, 208 (consistently referring to fair use as an "exception" to the copyholder's exclusive rights).

144. Campbell, 510 U.S. at 590. The Court's discussion of burdens was oblique. It came in the context of the Court's rejection of the lower court's use of a presumption against the defendant on the particular issue (market impact). The net effect of the Court's opmion was, thus, a wash; the fact that neither party would likely be able to produce any evidence on the issue adds to the intrigue of defining the burden.

145. See Charles P. Curtis, A Better Theory of Legal Interpretation, 3 VAND. L. REv. 407, 422-26 (1950) (arguing that statutes and contracts are best interpreted not by discerning author intent but by what the addressee reasonably understands of the directive. Section 107 arguably gives the user discretion to determine fairness provided he considers the specified factors. If she abuses her discretion, that might imdicate infringement.). 
authorship."146 This is an unusual legislative statement because it neither defines nor mandates. As a factual pronouncement, it may reflect a concept associated with "natural law" that a creator "owns" the rights in his creation prior to and independent of legislative conferral or regulation. ${ }^{147}$ The Oxford English Dictionary defines "subsists" in part as follows: "1) To have an existence as a reality; to exist as a substance or entity . . 3)b, To consist, lie, or reside in some specific thing."148 The verb "subsists" avoids the thorny issue of whether copyright is a privilege conferred upon authors or whether it inheres in the work to be enjoyed by the author, suggesting a preexisting imtegration of copyright protection and the work. The legislative wording may also contribute to the courts' persistent reluctance to make tough decisions about what works are subject to copyright. By making "copyright protection" the subject and "original works" the indirect object of a verb whose function in the sentence is very close to that of the verb "to be," the syntax suggests that the existence of copyright protection is inherent, and its "subsistence" in a work an almost inevitable consequence.

The sentence structure also implies that copyright protection subsists in objects whose nature any reader would already know. Thus, the sentence subtly deflects the reader from considering exactly which works are protected by copyright. The point may be easily understood if one tries to reverse the syntax to begin the sentence with "works of authorship," as in "[o]riginal works of authorship are protected by copyright." Unlike the original, this revision invites the reader's speculation about what works are intended to be afforded copyright protection and assumes an understanding of the predicate. One might object that whatever the implication of the main clause conferring copyright, the balance of the statutory sentence modifies "works" with an elaborate adjectival clause. A second sentence defines, by nonexclusive example, categories of "works." Nevertheless, despite the numerous words devoted to modifying "works," the syntactical structure of the main clause, the adjectival clause and the succeeding sentence of examples embody the conviction that "works" has a meaning that need not be denoted because the reader will intuit it.

146. 17 U.S.C. $\$ 102$ (a) (1994).

147. See, e.g., Millar v. Taylor, 4 Burr. 2303, 98 Eng. Rep. 201 (K.B. 1769) (involving a dispute over whether the first English copyright statute, the Statute of Anne, abolished the common law of copyright). The literature on the origins and philosophical justifications of intellectual property is vast. Two accessible recent works that describe the origins and present effects of "natural law," including "Inoral" or "authors' rights" theory are DRAHOs, supra note 91 at 13-33, and Woodmansee \& Jaszi, supra note 91 .

148. 17 The OXford English Dictionary 61 (2d ed. 1989). 


\section{B. The Incoherence of Fair Use Law: Judicial Approaches}

The courts have accepted this legislative distaste for definition and have also avoided determining whether unpublished materials constitute "original works of authorship" before deciding whether a given use is fair. Instead, courts have elided two clauses in the statute to suggest that copyright protection subsists in any "original expression." 149 A rigorous effort to define a "work" would make plain that many disputes concerning use of unpubhished materials cannot be resolved under traditional utilitarian copyright doctrine. It may be that there are legitimate interests that are not now protected by any recognized doctrine, whether copyright, contract, or tort, and that the courts have colluded with litigants to extend copyright doctrine, covertly, to provide a remedy.

Another reason for imprecision, if not incoherence, inay be the factual diversity of the "fair use" cases that have reached the Supreme Court. In fifteen years, the Court has decided a range of fair use cases: the effects of new technology (Sony); the "scooping" of a soon-to-be-published presidential memoir (Harper \& Row); duplication of "course packs" (MDS); and parody (Campbell). The utter incomparability of the facts in these cases precludes doctrinal refinement. Rather than reason incrementally by analogy ${ }^{150}$ from like cases, the Court repeatedly attempts

149. See, e.g., Harper \& Row, Publishers, Inc. v. Nation Enters., 471 U.S. 539, 548 (1985); Salinger v. Random House, Inc., 811 F.2d 90, 94 (2d Cir. 1987) (noting that "[t] he author of letters is entitled to copyright in the letters, as with any other work of literary authorship"). The opinion cites Meeropol v. Nizer, 560 F.2d 1061, 1069 (2d Cir. 1977); Folsom v. Marsh, 2 Story 100, 9 F. Cas. 342, 346 (C.C.D. Mass. 1841) (No. 4,901), and two treatises. Although parading much precedent and authority, the court failed to point out that the letters in Meeropol had been previously published, 560 F.2d at 1072 , or that the copier in Folsom lad used letters that had previously been assembled by George Waslington's heir and were owned by the United States and accessible to the public. For a detailed description of the facts underlying Folsom, see Patterson, supra note 91, at 432-33. For purposes of this Article, the point is that these letters, as compiled and previously published, constituted "works" even in the colloquial meaning of the word. The Second Circuit never considered whether these cases were apt prccedent for the proposition that a relatively few letters from Salinger's assorted, uncompiled, and unpublished letters, were also "works." For a discussion of the meaning of the term "work of authorship," see infra pp. 415-16, 431-32.

150. For an interesting argument for the utility of reasoning by analogy, see Cass R. Sunstein, On Analogical Reasoning, 106 HARV. L. REV. 741 (1993). Sunstein's advocacy of careful analogical reasoning to resolve sharply contested First Amendment issues, sucl as the legality of flag-burning, might be transferred to sharply contested copyright issues. The inethodology would provide direction to those who are unnerved by the indeterminacy of employing an "equitable rule of reason" to decide fair use cases. Sunstein's approach is a more detailed version of Weinreb's proposed method, that the courts should pay more attention to facts and less to deductive reasoning froni non-existent principle. Cf. Weinreb, supra note 16 , at 1138 . For example, liad the Second Circuit expressly considered whether quotations from Salinger's unpublished letters in a biograplyy were analogous to The Nation's quotations from the "heart" of Ford's memoir ahead of its conipetitor's licensed publication of excerpts, the court might have recognized the fact that both sources were unpublislied was only a partial likeness and equally important was the distinction that the memoirs were about to be published whereas Salinger's letters were to be withheld. If the Second Circuit had articulated this distinction, it would more likely have explained why Salinger's desire not to liave his letters revealed should trump a fair use claim. The point is not that the judgment would have been different. Rather, the opinion would 
to state overarching principle at a level of generality sufficient to encompass such diversity and to guide the lower courts. Had such a principle emerged and proved effective, the result would have validated the attempt; but it has not. ${ }^{151}$ The lower courts, if anything, have relied too much on principle at the expense of analogy and distinction.

If one confines the analysis to cases that are like each other in that they involve unpublished materials, one can see the misapplied principles. From the rhetorical efforts to camouflage the illogic and validate the judgments, one can also extract some sense of the concerns, however unarticulated, that underlie the judgments. ${ }^{152}$

\section{Harper \& Row}

I hope to show how the Supreme Court in Harper \& Row unnecessarily lowered the threshold of "copyright-ability" for unpublished works by equating expression in which the writer's feelings or attitudes might be discerned with "origimal expression," and how the Second Circuit took that one step further in Salinger to equate such expression with "works of authorship." I also hope to show that this perhaps unintended extension of copyright to almost any written expression was the consequence of a rhetorical strategy designed, not to secure that goal, but merely to support the judgments by appealing to imprecise, but emotionally and culturally appealing, ideas of creative autonomy and personal privacy.

The following discussion of the Supreme Court opinion in Harper \& Row is divided into two major components. The overview states the facts and holding, summarizes the Court's rationale, and evaluates the soundness of that rationale. The structural and syntactical analysis details the rhetorical strategies employed by the Court, whether consciously or not, in presenting its rationale. This "close reading" of the opinion is intended to support the argument that the Court unnecessarily invoked cultural constructs of authorial autonoiny and creativity where it might have inflicted far less damage on the fair use doctrine had it confined its rationale to the

have addressed what was arguably the real issue in the case instead of camouflaging it under a blanket protection for "unpublished" material.

151. Wendy Gordon's sophisticated description of "fair use" as a trope for "market failure" is relevant here. As Gordon recognizes that an economic utilitarian theory cannot fully resolve the problem of censorship, which represents a "market failure." Economic utilitarian theory is also of dubious validity for certain scholarly uses, where there is essentially no market for the work product. At base, the market failure theory is afflicted by the same weakness that afflicts all utilitarian theories. While it accounts reasonably for copyright as capital, it fails to account for its personal aspect, and so it cannot satisfactorily resolve the kind of dispute present in Salinger. Gordon, supra note 117; Wendy J. Gordon, An Inquiry into the Merits of Copyright: The Challenges of Consistency, Content, and Encouragement Theory, 41 STAN. L. REV. 1343, 1353, 1413-65 (1989).

152. Of course, I recognize the basic theoretical objection that any analyst's preliminary selection of particular cases as "like" fundamentally begs the question of the proper principle and criteria for analysis. 
obvious market impact The Nation's use had on Harper \& Row's financial interests.

An analysis of the structure and rhetoric of the inajority opinion in Harper \& Row demonstrates that the Court's bases for decision were, at best, buried in a case that was litigated as a conflict between copyright and the First Amendment. The opinion has been criticized for two reasons: 1) the majority's unwillingness to resolve the distinction between uncopyrightable fact and copyrightable expression; ${ }^{153}$ and 2) the inajority's "reading back" into the 1976 Act a common law copyright in first publication..$^{154}$ I will not rehash those points, or address the arguments that a public figure should enjoy greater or lesser copyright protection for literary expression regarding events to which he was a party or witness by virtue of his public position. Instead, I will examine specific passages to illustrate the argument that while the opinion conforms at first reading to a conventional utilitarian analysis of proprietary interests in copyright, its structure, syntax, and diction actually invoke a personal rights conception of copyright. I do not think that the majority actually intended to advocate such an "authors' rights" theory of copyright; instead, I think that rhetoric was used, confusingly, to bolster the judgment in a hard case.

\section{a. Facts of the Case}

In 1979, Harper \& Row published former President Gerald Ford's memoirs. The meinoirs contained previously unpubhished material concerning Watergate, Ford's pardon of former President Nixon, and in general, "Mr. Ford's reflections on this period of history, and the morality and personalities involved."'155 Harper \& Row licensed first serial rights to Time magazine to excerpt 7,500 words from Ford's account of the Nixon pardon. The Time article was to appear one week before shipınent of the memoirs, and Harper \& Row had a right to review it prior to publication. Time agreed to pay $\$ 25,000$, half of which was paid on signing.

Two to three weeks before the Time article was to appear, an editor at The Nation magazine obtained a "purloined" copy of the Ford manuscript m spite of Harper \& Row's efforts to keep the manuscript confidential. There was no evidence that The Nation or the editor had acted illegally. The editor summarized parts of the manuscript and excerpted verbatim quotes, totaling 300 words, from various parts of the 200,000-word memoir. These were incorporated in a 2,250-word article that focused on Ford's account of the Nixon pardon. As a result, Time cancelled its license for first serial rights and refused to pay the $\$ 12,500$ balance.

153. See Harper \& Row, 471 U.S. at 580 (Brennan, J., dissenting).

154. See Litman, supra note 15.

155. Harper \& Row, 471 U.S. at 542. 


\section{b. Holding of the Court}

Addressing only the use of the verbatim quotes, the Supreme Court found that while the quotes represented only a tiny percentage of the memoir, they took more than what was necessary to convey the "facts." The verbatim quotes at issue represented thirteen percent of The Nation's article and, most importantly, constituted the "heart" of the memoir. ${ }^{156}$ The Court held that the use was not fair, explaining that

[i]n using generous verbatim excerpts of Mr. Ford's unpubhished manuscript to lend authenticity to its account of the forthcoming memoirs, The Nation effectively arrogated to itself the right of first publication, an important marketable subsidiary right. For the reasons set forth below, we find that this use of the copyrighted manuscript, even stripped to the verbatim quotes conceded by The Nation to be copyrightable expression, was not a fair use within the meaning of the Copyright Act. ${ }^{157}$

The Court grounded its judgment in three ways. First, it asserted that the right of first publication protected unique interests in creative control over the form and timing of publication and in exploiting pre-publication rights. ${ }^{158}$ Second, it found that the public interest in a public official's memoir did not justify a more liberal fair use doctrine. ${ }^{159}$ Third, applying the four-factor test, it found the defendant's use unfair on all four counts. ${ }^{160}$

In effect, the Court's first rationale allowed it to avoid responding on the merits to a strong defense argument that The Nation "scooped" uncopyrightable fact from the memoir and that the use of any original expression was de minimis. Instead, the Court used the manuscript's unpublished status to justify an exclusive copyright protecting the creative process rather than the work itself. Superficially, the Court's strategy avoided the paradox that the same use at or immediately after publication would almost certainly have been fair. The Court's opinion suggests that an imdividual owns an exclusive, possessory imterest in the manner and timing of any revelation of facts, events or perceptions within his individual power to describe. As a corollary, the Court conflated the individual's "expression" of emotion with the statutory definition of "original" expression. Relying on the defendant's unfortunate concession that 300 words of verbatim quotes would be infringing unless excused by fair use, the Court's analysis hovers uncertainly over two quite different grounds for finding infringement. One could be the unexceptionable theory that the article, including the quotes, captured the essence of the memoir and thus

156. Id. at 564-65.

157. Id. at 548-49.

158. Id. at 548-55.

159. Id at 555-60.

160. Id. at 560-69. 
superseded the memoir. The other, which is far more questionable, is that the particular quotes were so original in themselves, so "expressive" of President Ford's particular feelings and viewpoimt, that to quote them for any purpose would necessarily infringe. Thus, their use would be infringing even though they represented a miniscule portion of the manuscript.

The Court mistakenly equates authorial emotion with original expression. It suggests that any individual's description of his thoughts will necessarily be copyrighted expression. It also overlooks the coincidence of fact and expression in that every expression is an artifact. Since every linguistic structure (other than copied ones) must be at least the product, if not a self-conscious description, of the creator's subjective consciousness, every such structure is original, if originality is equated with personal expression. Copyright protection would then be extended to any expression suggestive of the expressor's personality and essentially preclude any use of the expression as artifact to analyze the expressor's reactions to those events. The Court's rhetoric draws on a facile, contemporary association of creativity with individuality to validate the judginent that the use was unfair, despite the fact that no one's creativity or personhood was threatened in this instance. The Nation's article was a crass exercise in competitive corporate journalism whose effects were to frustrate a rival's ambition to be first to publish excerpts from the memoir and the publisher's desire to control the initial publicity "spin" for the book.

Unfortunately and unnecessarily, the Court's rhetoric was more powerful than its holding, and effectively created an enduring prcsumption against the fair use of any unpublished materials, thus lowering the threshold for copyright to any expression that might be deemed personal or reflective of personality. This unfortunate rhetoric laid the foundation for subsequent lower court decisions that heedlessly equate an individual's expression of any degree of subjectivity with "original works of authorship ... fixed in ... expression" subject to copyright protection. ${ }^{161}$ When combined with automatic statutory copyright, the effect is to confer a property imterest on virtually all expression. As a result, copyright

161. Norse v. Henry Holt \& Co., 991 F.2d 563, 565 (9th Cir. 1993) (finding fair use but making a similar assumption about excerpts from a poet's letters); Wright v. Warner Books, Inc., 953 F.2d 731, 737-38 (2d Cir. 1991) (finding fair use but assuming without analysis that small quotations from writer's journals were copyrighted expression); Salinger v. Random House, Inc., 811 F.2d 90, 94 (2d Cir. 1987) (making the blanket assertion that letters are copyright "as with any other work of literary authorship"). But cf. New Era Publ'g Int'l v. Carol Publ'g Group, 904 F.2d 152, 156 (2d Cir. 1990) (treating relatively small quotations as copyrighted but recognizing that "even passages used for their expression are intended to convey...the user's perception of... [the author's] hypocrisy and pomposity"). Unfortunately, no court to date has applied to unpublished materials this important distinction highlighted by New Era justifying fair use even of very "expressive" expression. 
subsists not just in "works of authorship" but in almost every expression of any individual. ${ }^{162}$

It is useful to identify the interests of the creator, Ford, and the copyright holder, Harper \& Row, that were damaged or threatened by The Nation's conduct. The interests were primarily commercial. Harper \& Row's license to Time of first serial rights exploited the latter's interest in generating sales and publicity by being first to publish excerpts from a newsworthy inemoir. Harper \& Row stood to gain the license fee, and by retaining a right to review the Time article, also hoped that the article would generate publicity, enhancing sales of the book. Time's article, scheduled one week before distribution of the meinoir and subject to review by Harper \& Row, would publicize the 1nemoir, stimulate consumers to buy the book, and by being first to market, influence the "spin" given the book by later reviewers and commentators.

Harper \& Row and Time lost the benefit of their bargain through The Nation's scoop if only because Time could no longer be first to the market with news of the memoir. As Justice Brennan's dissent notes, the record does not reveal whether Time withdrew because The Nation had quoted the bargained-for material or because the advance revelation of the "facts" in the memoir damaged the value of being first to the market. ${ }^{163}$

Notably, the personal interests that are so often associated with the revelation of unpublished material were not implicated. Ford may have lost royalty income attributable to Time's payment. Conceivably, Ford's royalties might also be diminished if the Time article would have stimulated more book sales than did The Nation's. Ford's privacy, however, was not jeopardized since the material was about to be published. Nor, despite the Court's reliance on this issue, was Ford's creative control over the form or timing of his expression jeopardized. The manuscript was complete before The Nation's article. While the Court noted some "inaccuracies" in the article, it did not point to any such inaccuracy or false impression generated by The Nation's use of verbatim quotes. ${ }^{164}$ At most, Harper \& Row's creative control over the "spin" that Time might have put on the memoir was jeopardized.

If the Court was protecting Harper \& Row's creative control over "spin," the analysis might have been clearer had the Court confined its analysis to the impact of The Nation article on the derivative work licensed to Time. If the Court had done so, the analysis would have turned on

162. An objection might be made that this has always been the scope of copyright in that there has never been a significant requirement of substantiality and that originality has been equated not with value but with individual effort. See, e.g., Bleistein v. Donaldson Lithographing Co., 188 U.S. 239, 250 (1903) (finding that a poster was copyrightable and rejecting the defendant's argument that the work lacked sufficient merit or distinction to be protected).

163. Harper \& Row, 471 U.S. at 602-03.

164. Id. at 564. 
whether The Nation had pirated an excessive amount of the derivative work or whether the article constituted commentary. A copyright holder undoubtedly has the right to hicense a derivative work before and after publication of the original, but it may not restrain commentary through licensing unless the commentary makes such extensive use of the original work that it constitutes a derivative work. ${ }^{165}$ The Court blurs this issue by explaining that the fourth fair use factor (commercial impact) requires an analysis of whether the use harms the market, not only for the original but for derivative works as well. ${ }^{166}$ This, however, begs the question because copyright does not protect the holder against commentary that harms the market for either the original or the derivative work. The Court could not rest its judgment on the argument that The Nation's article was a derivative work, regardless of whether Time's might have been. The Nation's article, if printed after the release of the Ford memoir, would likely have been deemed a fair use, as the Court came close to admitting. ${ }^{167}$

Plainly, the Court judged The Nation's conduct unsavory, perhaps even unethical, and unjustified by an important public need for access to information that would otherwise remain unknown. The Court also believed that by permitting The Nation's conduct, it would create a "public figure" exception to copyright, ${ }^{168}$ arguably diminishing the incentive for public figures to refiect and report on their activities. At the same time, the Court could not secure its judgment in the four statutory factors. Only the commercial impact factor plainly favored the plaintiff. The application of the nature of the use factor was arguable. In general, journalistic reporting on events involving public figures is favored. ${ }^{169}$ On the other hand, the Court objected to The Nation's evident desire to "scoop" Time. Although cast in copyright terms, that argument begs the question because it is only impermissible to invade the market for a copyrighted work by

165. E.g., Sundeman v. Seajay Soc'y, 142 F.3d 194, 203-04 (1998); Notes of Committee on the Judiciary House Report No. 94-1476, reprinted in 17 U.S.C.A. $\$ 107$ notes (discussing the propriety of quoting in reviews and criticism, among other sources).

166. Harper \& Row, 471 U.S. at 568.

167. The Court argued:

Our prior discussion establishes that the scope of fair use is narrower with respect to unpublished works. While even substantial quotations might qualify as fair use in a review of a published work ... the author's right to control the first public appearance of his expression weighs against such use of the work before its release. The right of first publication encompasses not only the choice whether to publish at all, but also the choices of when, where, and in what form first to publish a work.

Id. at 564. (citation omitted). The Court's reasoning here seems imconsistent with its decision that The Nation had published the "heart" of the memoir. Id. at 565. If true, such extensive use would not be fair even in a book review. Cf. id. at 600-01 (Brennan, J., dissenting) (arguing that the "heart" is actually the factual core, not the literary expression, of the memoir and that the use would have been appropriate in a book review or news report).

168. Id. at 557 (observing that The Nation's "theory... vould expand fair use to effectively destroy any expectation of copyright protection in the work of a public figure").

169. Id. at 555-58. 
impermissible use of the copyrighted work. Whether or not the nature or extent of the use was impermissible was exactly the issue. The amount used factor clearly favored the defendant. Even with respect to the nature of the copyrighted work factor the Court had to overcome two objections that copyright did not extend to facts and that, even if the expression were copyrighted, section 107 had extended the fair use exception to all copyrighted works, regardless of publication.

The Court's rhetoric is more successful at avoiding than answering the defendant's argument that the use was primarily factual and that the amount of copyrighted expression was minimal, if it existed at all. Despite the fact that Ford had completed his artistic and personal involvement with his ghost-written memoirs, and that the only control remaining was Harper \& Row's right to review Time's use of licensed excerpts, the Court's rhetoric is designed to inspire the reader's indignation by repeatedly emphasizing the threat the use of unpublished expression poses to the author and copyright holder's creative control.

If this case were just an example of a court justifying a decision by appeal to whatever legalistic rationale it believes its audience will accept, ${ }^{170}$ there would be little to remark. The dictum, however, has made it easy for later courts to avoid the hard questions of what constitutes a "work of authorship" worthy of copyright protection. ${ }^{171}$ More generally, the Court's rhetoric has delayed or even avoided discussion of the appropriate resolution between the personal claims associated with "authors' rights" and the public claims associated with access to accurate information and new works. ${ }^{172}$ By infusing mundane prose with the aura of inviolable personality, the Supreme Court has contributed to a copyright "culture" that endows every bit of personal expression with copyright without regard to its literary form or substantiality and without any realization that such a low threshold for copyright converts a wealth of unpublished material from artifact to personality.

170. See Duncan Kennedy, Freedom and Constraint in Adjudication: A Critical Phenomenology, 36 J. LEgAL EDuc. 518, 528-30 (1986) (arguing that a judge uses those rationales that he thinks will appear legitimate and thus may persuade his readers).

171. See cases cited supra note 161 .

172. One reason for this avoidance results from the nature of litigation. In any dispute of this nature, the author's claims are tangible and embodied in a copyright holder willing to pursue expensive litigation (in Ford's case, only indirectly through the good offices of his publisher). Meanwlile, the public interest, particularly the public future interest in access to information potentially cloistered by some as-yet-unrealized application of this precedent, is as remote and intangible as this sentence structure suggests. Of course, one would hope that judges, particularly Supreme Court Justices, would be especially cognizant of the need to avoid ad hominem arguments. But whether or not the Court was particularly solicitous of Ford, the man, or merely pretending to further a different agenda, one can liardly dispute the fact that the rhetoric in the Court's opinion in Harper \& Row is designed to invite sympathy for this apparently innocent former President. 


\section{c. Structural and Syntactical Analysis}

The thirty-page Harper \& Row opinion has five parts. Part I recites the facts and the lower court proceedings. Part II provides an overview of a utilitarian theory of copyright and redefines the issue before the Court. Part III (Section A) examines the particular application of fair use doctrine to unpublished materials; (Section B) addresses the applicability of the First Amendment and fair use principles to works by public officials. Part IV apphies the four factors of Section 107, and Part V briefly summarizes the Court's holding. The following analysis focuses on Parts II, III (A) and IV.

It is significant that the Court does not address the four statutory factors until Part IV, nearly twenty pages into the opinion. ${ }^{173}$ Indeed, the court's analysis of the four statutory prongs reverts repeatedly to a single factor, the unpublished nature of the work. ${ }^{174}$ More interesting are the rletorical techniques by which the Court treats the unpublished status of the memoirs as determinative.

\section{i. Part II}

Part II of the opinion contains five paragraphs, wlose logical connection is subtle, if not obscure. ${ }^{175}$ The first paragraph begins by disclaiming that the Court intends any regressive or suppressive interpretation of copyright: "We agree with the Court of Appeals that copyright is imtended to increase and not to inupede the harvest of knowledge."176 Yet, after having asserted its good faith, the Court quickly faults the lower court for having given "insufficient deference to the scheme estabhshed by the Copyright Act for fostering the original works that provide the seed and substance of this harvest."177 The paragraph concludes with a utilitarian theory of copyright: "The rights conferred by copyright are designed to assure contributors to the store of knowledge a fair return for their labors." 178

The second paragrapl begins with an elaboration of utilitarian theory. The Court explains that copyright is intended to "motivate the creative activity of authors" and that copyright is a legally recognized inonopoly, awarded to an author in the public interest. ${ }^{179}$ Mid-paragraph, however, the Court abruptly concludes that the legal incentives offered by copyright served their intended purpose in this case. The Court notes that "[t]his

173. Harper \& Row, 471 U.S.at 560-69.

174. See supra note 51 for a discussion of the extent to which the statute compelled the Court to "consider" all four factors.

175. Harper \& Row, 471 U.S. at 545-49.

176. Id. at 545 .

177. Id. at 546 .

178. Id. at 546 .

179. Id. 
principle applies equally to works of fiction and nonfiction," and proceeds to summarize how hard Mr. Ford and his publishers worked to produce the memoir:

The book at issue here ... was two years in the making, and began with a contract giving the author's copyright to the publishers im exchange for their services in producing and marketing the work. In preparing the book, Mr. Ford drafted essays and word portraits of public figures and participated $m$ hundreds of taped interviews that were later distilled to chronicle his personal viewpoint. It is evident that the monopoly granted by copyright actively served its intended purpose of mducing the creation of new material of potential historical value. ${ }^{180}$

Ostensibly, the Court is leading us to conclude that Ford and his collaborators are entitled to a fair return on their labor and that it is consistent with the constitutional and statutory scheme to confer a copyright upon the work. But the copyright in the work as a whole was never challenged by the defendants and so this conclusion is irrelevant. The crucial, but unsubstantiated, inference appears in the last sentence quoted above, that "[i]t is evident" that copyright induced the creation of "new material of potential historical value." While Ford's publishers might not have engaged him without the protection of copyright, the Court cites no evidence that Ford was motivated by the prospect of financial reward in initially producing his memoirs. Further, the Court evades the task of defining what, exactly, was copyrighted. The Court describes the work at issue as "new material of potential historical value." This description lacks substance; it is alinost self-evident that Ford's compilation and ordering of his recollections and viewpoint are potentially valuable and, at least in structure and coverage, "new" and original. Yet the conclusion that constituent descriptions of events or people are new or original is not selfevident unless one assumes that any description, conveyed from the viewpoint of an author is necessarily new and original.

A possible response to this critique is contained in the third paragraph of Part II. The Court recites the bundle of rights conferred by copyright, noting that copyright does not extend to facts or ideas. The Court concludes the paragraph by acknowledging that "copyright is limited to those aspects of the work-termed 'expression'-that display the stamp of the author's originality." At first blush, this is a conventional restatement of established doctrine, but im context, the language subtly shifts the reader's attention from the originality of the work to the originality of the author. In this sentence, the Court moves from the indisputable conclusion that the memoirs as a whole were copyrighted to the questionable inuplication that

180. Id.

181. Id. at 547 . 
those constituent descriptions within the work that displayed the author's subjectivity were copyrighted. The structure of these paragraphs urges a conclusion that the expression of a viewpoint, no matter how mundanely written, can be copyrighted.

In the fourth paragraph, the Court repeats its strategy of asserting uncontroverted commonplaces of copyright doctrine. The Court notes that "[c]reation of a nonfiction work ... entails originality," 182 and that there is no dispute that the unpublished memoir, as a whole, was copyrighted. In the middle of that fourth paragraph, the Court briefly alludes, for the only tine in the entire opinion, to a critical issue that had concerned the lower courts: the separation of uncopyrightable fact from copyrighted expression. ${ }^{183}$ The Court then admits that "[p]erhaps the controversy between the lower courts in this case over copyrightability is more aptly styled a dispute over whether The Nation's appropriation of unoriginal and uncopyrightable elements encroached on the originality embodied in the work as a whole."184 The Court admits that there is a signiflcant and unresolved issue about copyrightability: "Especially in the realm of factual narrative, the law is currently unsettled regarding the ways im which uncopyrightable elements combine with the author's original contributions to form protected expression."185 With a blandness and placement that camouflages the legal signiflcance of the concession, the Court prepares to conclude without addressing the issue by asserting that "respondents do not dispute that verbatim copying of excerpts of the manuscript's original form of expression wonld constitute infringement unless excused as fair use."186

Part II concludes with the confident assertion that "[w]e need not reach these issues, however, as The Nation has admitted to lifting verbatinı quotes of the author's original language totaling between 300 and 400

182. Id.

183. See Harper \& Row, Publishers, Inc. v. Nation Enters., 723 F.2d 195, 205 (2d Cir. 1983), cited in Harper \& Row, 471 U.S at 544. The technique of placing unfavorable material in the middle of a paragraph is a common technique in persuasive writing. See, e.g., HelENE S. SHAPO ET AL., WRITING AND ANALYSIS IN THE LAW 354 (4th ed. 1999).

184. Harper \& Row, 471 U.S. at 548.

185. Id.

186. Id. Respondents' purported "concession" simply restates the law; respondents could hardly have disputed the point. The Court seems, however, to imply that the respondents conceded that the verbatim quotes were, in themselves, copyrighted expression. Perhaps they did so at oral argument, and if so, they made a mistake. I do not read the briefs, however, to make so bold a concession. The Court's articulation of the respondents' position oversimplifies their argument. They had argued, strenuously, that the quotes were, even if copyrighted, subject to fair use in part because they einbodied uncopyrightable fact. Respondents' Brief at 10-24, 38-39, Harper \& Row (No. 83-1632). While I would have preferred a stronger argument that the isolated quotes were not independently copyrighted, the respondents' argument was sufficient to preserve for the Court's review the question of whether the quotes were copyrighted "works" of original expression or factual statements. If, in fact, the respondents waived this issue, then Harper \& Row has no precedential value for purposes of distinguishing origiual froin factual expression. 
words and constituting some $13 \%$ of The Nation article." 187 However illadvised the respondents' purported concession may have been, the Court's subsequent reliance on the verbatim quotation simply begs the question of fair use. Instead, with this rhetorical flourish, the Court avoids precisely the issue that bedevils any use of "expression" to document a fact, whether it is a fact described by the expression or embodied in the expression.

It is not clear, however, that the quotes' "verbatim" character should be so determinative. There are three basic ways to "copy" a portion of another's expression: quotation, paraphrase, or summary. Obviously, the further the copier departs from verbatim quotation, the more easily she can maintain that she is reporting uncopyrightable fact or idea. Nonetheless, the fact that quotes are verbatim, and thus take some "original expression," should not end the analysis. ${ }^{188}$ If a finding of verbatim quotation, with some exception for de minimis citation, did end the analysis, then any fact embodied in, rather than merely described by, written expression ${ }^{189}$ could be suppressed for the copyright term. For example, if I write a letter that includes the sentence, "1 would like to pulverize that pusillanimous punk, $P$, into pulp," a biographer or a reporter who quoted that sentence without permission might infringe my copyright regardless of whether his purpose

187. Id. at 548. Interestingly, the plaintiff-appellees' petition for rehearing at the Second Cireuit had objected to that court's "stripping" the alleged expression down to "approximately 300 copyrightable words." Petition for Rehearing En Banc 1, citing Slip Op. at 191 (83-7277/7327, filed Dec. 1, 1983).

188. The brevity of the majority's subsequent analysis implicitly acknowledges the ueed for further analysis.

189. Lawyers should appreciate the distinction between texts as artifacts and texts as meaningtransmitters. See, e.g., Wayne C. Booth, The Company We Keep: An Ethics of Fiction 36-37, $92-$ 97 (1988) (disputing the claim by some modern critics that the aesthetic form of a literary work can be observed without siunultaneously evaluating its message). Contract doctrine unanifests this distinction, particularly in the parol evidence rule, where a legal distinction is drawn between the text of an agreement as an artifact with intrinsic ineaning independent of what its signatories may have meant, or intended it to mean, and the text as an expression of tbe intent of the signatories. No judge would presume to resolve a contract dispute witbout verbatim quotation of the text, whether or not other evidence inay be adduced to support or contradict the reader's understanding of the text. Yct, in copyrigbt disputes, the courts have assumed, without careful analysis, that a biographer can provide the "facts" without quoting the subject's expression, overlooking the argument that, like a contract, a subject's text inay embody meaning, not just describe the author's intention. A corollary is that in such cases, admittedly rare, the biographer cannot establish the fact of the text, the artifact, the meaning that its very existence suggests, without verbatim quotation. Just as no court would accept allegations of written contracts without documentary proof, a biographer may argne that no reader should accept allegations about what a subject has written without documentary proof. This does not seem an exceptionable proposition, yet it lies at the heart of all these disputes. It may be that judicial insensitivity to biographer's needs for quotation to establish the fact of expression, and the accuracy of its interpretation may be a consequence of the judicial process that typically allows a court to compel production of documentary evidence, even against its possessor's will. Litigants and judges do not confront the same legal obstacles in accessing a copyrighted text. Cf. Harper \& Row, 471 U.S. 539 app. at 570-79 (quoting verbatim the contested passages that The Nation had quoted). On the other hand, copyrighted material such as coinputer source code, which embodies a party's commercial trade secrets, is protected from production in open court. 
was to document that I hated $\mathrm{P}$, likely murdered $\mathrm{P}$, or that I was given to vituperation. ${ }^{190}$

Furthermore, the Court never states why it need not consider the interaction of fact and expression. One possible implication is that verbatim quotes cannot be primarily factual because they are verbatim. If meant literally, this statement would preclude any verbatim use of a written description of facts and any quotation used to demonstrate what the writer said or believed. ${ }^{191}$ Instead, this statement's reach should be understood solely im the context of The Nation's concession that the verbatim quotes were copyrightable expression. ${ }^{192}$ The next sentence in the final paragraph of Part II reveals the Court's true concern: not the quality or the content of the quotations, but the fact that they were as yet unpublished that requires the finding of infringement. ${ }^{193}$

The refusal to decide whether the The Nation had appropriated noncopyrighted factual elements or copyrighted expression is imcomprehensible unless the Court felt that, in fact, it could not justify treating the article, mcluding the quotes, as anything more than a de minimis appropriation of original expression. ${ }^{194}$ Instead, the Court must have reasoned backwards from its conviction that The Nation had deprived Harper \& Row of the value of first serial rights for an about-to-bepublished "big" book. In order to justify such a finding, the Court resorted to the fiction that unpublished expression remains essentially imseparable from the creator's identity because, at least theoretically, it remains subject to change or may even be withheld altogether. This focus explains the Court's reduction of the issue to the 300 verbatim quoted words. While the Court could not have realistically indulged its fiction of artistic control over the plan and structure of a large book a few weeks before publication, it could invoke the idea that Ford might rewrite particular sentences or cut them altogether in the count-down to publication. Cleverly, the Court employed this fiction to evade deciding whether the sentences were factual or original expressions. That did not matter because Ford and his publishers still might change thein. Thus, the Court found it difficult to punish a commercial "wrong" under the traditional fair use factors except by invoking the personal creative integrity of the writer.

190. Readers who find my sentence unworthy of copyright protection should compare it with sentences of former President Ford that the Court found to be "original expression." Harper \& Row, 471 U.S. 539 app. at 570-79.

191. In fact, this is how the Second Circuit interpreted the language in the Salinger opinion.

192. Harper \& Row, 471 U.S. at 549.

193. Id. (stating that "The Nation effectively arrogated to itself the right of first publication").

194. It is not clear why the Court was unwilling to use plaintiffs' argument that The Nation's article had appropriated too much of the memoir's plan and arrangement by summarizing the focal scenes involving Nixon's pardon. See Petitioner's Brief at 15-16, 32-33, Harper \& Row (No. 83-1632); Petitioners Reply Brief at 3, Harper \& Row (No. 83-1632). 


\section{ii. Parts III \& IV}

In Part 111 (A), the Court emphasizes the right of first publication's singular immunity froin fair use by einphasizing the need to provide authors and publishers with an exclusive "period encompassing the work's imitiation, its preparation, and its grooming for public dissemination."195 The problem in this case lies in the fact that The Nation had not interfered with a work in progress; the quotes would appear verbatim in the memoir and their value, both cominerically and artistically, would remain unspoiled. In this section, the Court's opinion slides almost imperceptibly from relying on Justice Story's opinion in Folsom v. Marsh ${ }^{196}$ in support of the proposition that fair use precludes use that supersedes the objects of the original work, to the unrelated inference that the right of first publication protects cominercial interests at least as much as privacy concerns. ${ }^{197}$

In Part IV the Court finally addresses the four statutory factors. In discussing the second factor, the nature of the copyrighted work, the Court aggregates divergent rationales in such a way as to lead the reader to conclude that the quotes must be copyrighted because of The Nation's affront to the copyright holder's creative control. The Court begins by acknowledging the difficulty of differentiating fact froin expression in historical narrative or autobiography, but then concedes that "[s]oine of the briefer quotes from the memoirs are arguably necessary adequately to convey the facts; for example, Mr. Ford's characterization of the White House tapes as the 'smoking gun' is perhaps so integral to the idea expressed as to be inseparable from it." ${ }^{198}$ Nevertheless, the Court sidesteps the issue, noting that "The Nation did not stop at isolated phrases and instead excerpted subjective descriptions and portraits of public figures whose power lies in the author's individualized expression. Such use, focusing on the most expressive elements of the work, exceeds that necessary to disseminate the facts."199

After so concluding, the Court returns to its earlier discussion in Part 11 addressing the importance of protection when a work is unpublished. The Court reiterates its finding that the right of first publication encompasses the "choices of when, where, and in what form first to publish a work."200 Then, without transition, the Court devotes a paragraph to the copyright holder's interest in confidentiality and "creative control," noting that The Nation's "clandestine" publication was "hastily patched together

195. Harper \& Row, 471 U.S. at 555.

196. 9 F. Cas. 342 (C.C.D. Mass. 1841) (No. 4901).

197. Harper \& Row, 471 U.S. at 552. See the discussion of the Second Circuit's use of this inference in Salinger v. Random House, Inc., 811 F.2d 90 (2d Cir. 1987), infra note 232 and accompanying text.

198. Harper \& Row, 471 U.S. at 563.

199. Id. at 563-64.

200. Id. at 564 . 
and contained 'a number of inaccuracies."'201 Finally, the Court concludes the paragraph, stating: "A use that so clearly infringes the copyright lolder's interests in confidentiality and creative control is difficult to cliaracterize as "fair." 202

Throughout its opinion, the Court consistently einploys rletoric designed to invoke cultural constructs of artistic integrity and confidentiality, to trump any concerns over the individuality of Ford's quoted expressions. The Court does not quite say that Mr. Ford's expression is original or umque, yet its use of the adjectives "subjective," "individualized," and "expressive" in referring to Mr. Ford's role or effort in generating the expression strongly implies that any expression that is the product of a subjective consciousness is copyrighted. ${ }^{203}$

The concluding paragraph on factor two is simply illogical. ${ }^{204}$ The paragraph describes Harper \& Row's contractual arrangements designed to ensure confidentiality and control over the Time article. The Court iniplies that because Harper \& Row had legitimate interests and contractual expectations of confidentiality and of creative control over the Time article that were dashed by The Nation's conduct, the use was unfair and the copyright had been infringed. The logical difficulty of the Court's conclusion is that a party's private contracts cannot confer copyright beyond that which the statute bestows. Concomitantly, a non-party's circumvention of those contracts does not necessarily make the use unfair. For example, no court would find that an investigative journalist's quotation of a newsworthy document was unfair simply because the document's author attempted to ensure that its contents remained confidential.

Next the Court inoves to the third factor, the amount and substantiality of the use. The Court acknowledges that the quotes constituted "an

\footnotetext{
201. Id.

202. Id.

203. The Nation's quotes are printed in the Appendix to the opinion, id. at 570-79. Even the dissenting Justice Brennan concedes that six of the quotes were drawn from the "most poignant expression in the Ford manuscript ... [reflecting] events or perceptions about President Nixon." Id. at 598-99. Yet it is hard to see how the fact that these quotes were among the most poignant in the book, or that they reflected Ford's perceptions and feelings, justifies extending them statutory protection as unique or original forms of expression. The quote with the inost original form of expression is difficult to distinguish from a recitation of fact: "[Nixon] was stretched out fiat on his back. There were tubes in his nose and mouth, and wires led from his arms, chest and legs to machines with orange lights that blinked on and off. His face was ashen, and I thought I had never seen anyone closer to death." Id. at 599 n.22. Perhaps such writing should have the less rigorous copyright protection accorded to the organization of factual compilations, such as directories. See generally Feist Publ'ns, Inc. v. Rural Tel. Serv. Co., 499 U.S. 340 (1991) (holding that telephone directory entries conpiled in a white pages were uncopyrightable facts). A creative work can become a "fact" in the environment of other creators. See Wendy J. Gordon, Reality as Artifact: From Feist to Fair Use, 55 J. L \& ConTrmp. ProBs. 93 (1992).
}

204. See Harper \& Row, 471 U.S. at 564. 
insubstantial portion" of the memoir. ${ }^{205}$ The Court relies, however, on the District Court's finding that "The Nation took what was essentially the heart of the book." 206 The Court further explains:

A Time editor described the chapters on the pardon as "the most interesting and moving parts of the entire manuscript."... The portions actually quoted were selected by [the editor of The Nation] as among the most powerful passages in those chapters. $\mathrm{He}$ testified that he used verbatim excerpts because simply reciting the information could not adequately convey the "absolute certainty with which [Ford] expressed himself," . . . or show that "this comes from President Ford," ... or carry the "definitive quality" of the original .... In short, he quoted these passages precisely because they qualitatively embodied Ford's distinctive expression. ${ }^{207}$

The Court concludes: "[T] he fact that a substantial portion of the infringing work was copied verbatim is evidence of the qualitative value of the copied material, both to the originator and to the plagiarist who seeks to profit from marketing soineone else's copyrighted expression."208

The Court's reasoning is circular. The Court first acknowledges that the quoted material was not quantitatively substantial. It then quotes The Nation's editor to establish the qualitative importance of the quotes to The Nation. The Court then uses the quantitative substantiality, relative to The Nation's article, as evidence of the qualitative value of the quotations to all the parties. The concluding clause is comparably circular and begs the question of whether the use was fair. Presumably a user only quotes material of value. The lexical slip of characterizing the user as a plagiarist, ${ }^{209}$ despite the fact that The Nation had obviously attributed the quotes to Ford, reveals the depth of the Court's conviction that The Nation was morally at fault.

Most importantly, the Court fails to discern a crucial distinction in the editor's testimony. One might argue that Ford's verbatim expression was used so as to convey factual information about Ford's emotions and attitudes as precisely as possible. Even if the Court's evaluation of the editor's and The Nation's conduct was accurate, that it was primcipally a self-interested commercial preemption dressed up as service to the First Amendinent, the Court should have recognized a serious issue here: that idea, fact, and expression may be imtegrated to such an extent that the expression can either be an idea, a fact, or both.

205. Id.

206. Id. at 564-65 (quoting Harper \& Row, Publishers, Inc. v. Nation Enters., 557 F. Supp. 1067, 1072 (S.D.N.Y. 1983)).

207. Id. at 565 (citations omitted) (alteration in original).

208. Id.

209. Id. 
Use of the word "heart" to describe that which The Nation took from Ford's memoirs is also illustrative of a deeply held sense of violation. There is a conjunction between the notion that Ford's words were particularly expressive of emotions that he felt and the idea that The Nation, in quoting those words, took the "heart" of the book. The Court suggests that The Nation took the most imteresting part of the book, the portion that would likely generate the biggest readership. As the dissent points out, however, this does not mean that the quoted heart is necessarily expression particularly deserving of extraordinary copyright protection. The Court has simply moved from the undemable fact that the memoir as a whole was a work, if for nothing else than that its organization of events and viewpoimt were original to Ford and his writer, to the conclusion that any verbatim quotes from the most interesting parts of the book necessarily infringed the copyright $\mathrm{m}$ the work as a whole. Such a conclusion may have been justifiable and unremarkable had the rationale been that the quotes unfairly captured the essence of the whole, but not on the stated rationale that the quotes were themselves singularly expressive.

By evading the threshold issue of copyrightability the Court opimion invokes an intuitive definition of personal autonomy to resolve implicitly a dispute about commercial fair play. By focusing on the right of first publication, including an irrelevant concern for creative control, the Court nearly equates creative control over the text with control over marketing strategies. In so doing, the Court places a "penumbra" of personal privacy and autonomy over a commercial conflict between two rival journals.

Even given the assumption, however valid, that unpublished materials deserve special analysis, one still ought to assess the nature of the unpublished work: was it the type typically prepared for publication or the type typically prepared for some other purpose, such as communicating with a friend? If the case involves material for which the creator is likely to have self-consciously conceived of himself as creating a work, possibly for publication, then presumably the copyright law should be interpreted in such a way as to reflect the incentives for creating and publishing such work.

The principal incentive is the expectation of a period of exclusive ownership, particularly the right of first publication, which ensures to the creator some return for his labor and the publisher some return for the cost of acquiring, printing, marketing, and distributing the work. The principal threat to this expectation is the "scoop," publication of the manuscript by others who neither pay the creator for his labor nor incur the pubisher's development costs (such as scouting and editing manuscripts). The copier engages in precisely the forn of competition that induced the London booksellers to push for the exclusive rights enacted in the Statute of Anne. In this the material's unpublished status is barely relevant because the damage to the creator's and publisher's economic expectations are likely to 
be similar whether the copier publishes the manuscript just before, at the same time as, or very shortly after the original publisher's publication date. The creator, Ford, his ghost writer, and his editors had finished their work. Thus, the Supreme Court's emphasis on the unpublished nature of the Ford manuscript is largely beside the point. Since it had already licensed Time to excerpt the same portions of the memoir, Harper \& Row could not have expected the revelations, even if verbatim quotations, to damage sales of the book. The effect on the market for the memoirs was probably minimal. Thus, in my view, the analysis of whether The Nation's use infringed Harper \& Row's rights in the memoir should have been the same whether The Nation published just before, at the same time, or just after the memoir's publication date.

The Nation's scoop had a commercial impact, not because the memoir was unpublished but because Time's article was as yet unpublished; the Nation's scoop deprived Time, and its licensor Harper \& Row, of the benefit of their bargain that Time should be first to the market with excerpts about the Nixon pardon. ${ }^{210}$ The fair use analysis should have analyzed the effects of the use upon the market for the 7,000 words licensed to Time. It would have been easier for the Court to have found that the Nation's summary and 300 word quotes used a substantial portion of that licensed derivative work in a way that directly superseded the market for the Time article. Such a pragmatic resolution, however, would not have had the rhetorical appeal of the Court's invocation of author's rights over personal expression and thus might not have had sufficient weight to suppress the defense arguments that a public official should not be able to wrap "public" information in copyrighted expression, or that The Nation's use was excused by the First Amendment's protections for news reporting.

\section{Salinger}

If the Supreme Court's emphasis on the "unpublished" nature of the Ford's memoir was unnecessary to the judgment in Harper \& Row, then the Second Circuit's subsequent reliance on that point was erroneous. If The Nation did truly concede that the particular quoted expressions were each and all original and not factual, subsequent courts should not have used Harper \& Row as precedent for the copyrighted status of excerpts. In Salinger v. Random House, Inc., ${ }^{211}$ the Second Circuit indulged in a

210. Time Magazine, of course, was not a plaintiff. Indeed, as a likely practitioner of the occasional "scoop," Time may have had conflicting interests in the outcome of this case. While Time might have preferred to preserve the journalistic "scoop," it could have argued that The Nation had interfered with its contract with Harper \& Row. The First Amendment issues, however, probably made it unlikely that a commercial competitor could win an action for tortious interference. In general, however, such an action would be a much more direct way to remedy the kind of commercial mjury here.

211. 811 F.2d 90 (2d Cir. 1987). 
negative inference from Supreme Court dicta to create a presumption against the fair use of unpublished material, and applied that presumption to find a very different use of very different unpublished material to be unfair. As in Harper \& Row, the Second Circuit opinion seems grounded $\dot{\mathrm{m}}$ an undefined preference for seemly conduct, and the fair use analysis is strained to achieve the desired outcome. If Salinger had simply joined the ranks of poorly reasoned opinions, there would be no reason to discuss it here. Unfortunately, as Part II of this Article described, its inipact on the publishing industry was profound and enduring.

\section{a. Facts of the Case}

The facts of Salinger are very briefly described here. In 1986, Ian Hamilton, a successful biographer of literary figures, completed a draft of a biography of J. D. Salinger, author of The Catcher in the Rye, and other novels and stories. Hamilton had found in the archives of various university libraries and incorporated "very substantial quotation from approximately $70^{3212}$ unpublished letters that Salinger had written to friends. Salinger obtained galley proofs of the biography and immediately objected to publication of the biography unless all of the unpublished letters were deleted. ${ }^{213}$ Salinger also registered seventy-nine unpublished letters for copyright. ${ }^{214}$

In response, Hamilton revised the biography, replacing quotes with paraphrases. Salinger sued for a preliminary injunction barring publication of the biography. ${ }^{215}$ The district court denied the injunction, holding that the defendants had made a sufficiently powerful showing that they would prevail in a fair use defense. ${ }^{216}$ Leval, the presiding judge, found that Hamilton's taking of copyrighted expression was "limited to about 30 instances of the use of a word or a phrase or an image. In the rarest case, a complete sentence is taken." ${ }^{217}$ Leval rejected the defense argument that Harper \& Row precluded any use of unpublished materials and held instead that the other three fair use factors favored Hamilton's use. ${ }^{218}$ Leval also noted that the injury, if any, to Salinger resulted not from copyright infringement but "trespass[] on his wish for privacy."219

212. Salinger v. Random House, Inc., 650 F. Supp. 413,417 (S.D.N.Y. 1986), rev'd, 811 F.2d 90 (2d Cir. 1987).

213. Salinger, 811 F.2d at 93 .

214. Id.

215. Id.

216. Salinger, 650 F. Supp. at 428.

217. Id. at 423.

218. Id. at 423-26.

219. Id. at 426. 


\section{b. Holding of the Court}

The Second Circuit disagreed, and put much more emphasis on the unpublished nature of the letters. The court faulted the district court for failing to include paraphrase in its calculation of the amount of the taking, ${ }^{220}$ and found that fifty-nine passages of the biography contained close paraphrasing and "somewhat more than 200 words remain quoted."221 In particular, the court found that the book used materials from forty-four letters, and that it copied, either by quote or close paraphrase, protected sequences constituting at least thirty-three percent of seventeen letters and at least ten percent of forty-two letters. ${ }^{222}$ The court noted that, in an undisclosed number of instances, the paraphrased material exceeded ten lines from a single letter. ${ }^{223}$ The court piously concluded that

[t]o deny a biographer like Hamilton the opportunity to copy the expressive content of unpublished letters is not ... to interfere in any significant way with the process of enhancing public knowledge of history or contemporary events. The facts may be reported.... But Salinger has a right to protect the expressive content of his unpublished writings for the term of his copyright, and that right prevails over a claim of fair use under "ordinary circumstances." 2224

The court assumes, without analysis, that the quoted and paraphrased expressions are indeed works of authorship: "To a large extent the appropriate legal principles are not in dispute on this appeal, though their application is seriously contested. The author of letters is entitled to a copyright in the letters, as with any other work of literary authorship." ${ }^{.225}$ The court cites Meeropol v. Nizer ${ }^{226}$ and Folsom v. Marsh ${ }^{227}$ in support of this proposition, conveniently omitting that both cases involved substantial quotations of abridgments of collected letters that had been previously published. The court also fails to note that it had remanded for findings on whether the use was fair in Meeropol. In a footnote, the Salinger court

220. Although beyond the scope of this Article, the court's reasoning on this point is selfcontradictory. It includes paraphrasing in computing the amount taken. Salinger, 811 F.2d at 97 . At the same tine it accepts Salinger's argument that the awkward paraphrasing might damage the market for his letters by distorting the quality of his prose style. Id. at 99. If Hamilton's paraphrase nisrepresented the charactcr of Salinger's original expression, then Hamilton had not "copied" that expression.

221. Id. at 93 .

222. Id. at 93,98 .

223. Id. at 98 .

224. Id. at 100. Interestingly, the Court never even considers the possibility that the expressive content was, itself, a fact that a biographer might legitimately wish to report and validate through quotation. See supra note 203 (discussing the same issue with respect to Harper \& Row).

225. Salinger, 811 F.2d at 94 .

226. 560 F.2d 1061, 1069 (2d Cir. 1977).

227. 9 F.Cas. 342,346 (C.C.D. Mass. 184I) (No. 4901). 
observes the closeness of Hamilton's paraphrase of part of a letter without any analysis of what aspect of the expression is copyrighted or why. ${ }^{228}$

Even if the Second Circuit properly added the paraphrases to the total amount of copyrighted expression, the key error was the court's rhetorical strategy, particularly its rehance on Harper \& Row to invoke a presumption against the use of unpublished materials. The Supreme Court had used the rhetoric of personal autonomy and privacy to bolster a judgment in a purely commercial dispute; paradoxically, the Second Circuit used that dictum to interpret the copyright statute to protect a privacy interest all the while characterizing the interest as commercial.

\section{c. Structural and Syntactical Analysis}

The opinion begins its fair use analysis by stating that Harper \& Row must guide it. ${ }^{229}$ The court then draws a negative inference from the Harper $\&$ Row Court's discussion of the right of first publication and foregoes analysis of what exactly was copyrighted in Salinger's letters. The Second Circuit cmphasizes the care with which it has read Harper \& Row:

228. Salinger, 811 F.2d at 93 n.2. The court compares Salinger's description of his disapproval of Oona O'Neill's marriage to Charlie Chaplin with Hamilton's paraphrase. Salinger's prose reads:

I can see them at home evenings. Chaplin squatting grey and nude, atop his chiffonier, swinging his thyroid around his head by his bamboo cane, like a dead rat. Oona in an aquamarine gown, applauding madly from the bathrooin. Agnes (her mother) in a Jantzen bathing suit, passing between them with cocktails. I'm facetious, but I'm sorry. Sorry for anyone with a profile as young and lovely as Oona's.

Id. The court faults Hamilton for paraphrasing the scene rather than simply "report[ing] the fact that Salinger was distressed that O'Neill had married Chaphin or that in his mind he imagined how disastrous their hife together must be." Id. Without examining what about Salinger's quote is original, the court goes on to fault Hamilton for paraphrasing the "briefest similes." For example, Salinger's sentence, "He looks to me like a guy who makes his wife keep a scrapbook for him" had beome Salinger "had fingered [Wilkie] as the sort of fellow who makes his wife keep an album of his press cuttings." Id.

The longer Chaplin quote is undemably original, not so unuch for its syntax or word choice as for its creation of a theatrical scene. Perhaps it deserves copyright as a work of authorship despite its brevity. Even if the outcome is correct, the analysis is superficial because the court utterly fails to perceive any conceivable reason for a biographer to document by quote that his subject created this particular scene. That Salinger's impulse to react in that way to the marriage is itself a biographical fact; the court's suggestion that Hamilton might have confined himself to the "facts" does not capture this issue at all. What "fact" did the court have in mind, that Salinger disliked Chaplin, or was jealous of him? Did the court seriously believe that the quahty of Hamilton's biography would be comparable for readers had Hamilton confined himself to stating those facts? Are those the proper facts? Is the quoted passage reducible to those facts? Instead, the prose, like a self-portrait, indelibly conveys information about the author's persona.

The court's subsequent comment about similes further discredits the analysis by revealing the court's utter insensitivity to the question of what constitutes a copyrightable work. The sentence standing alone revcals only the slightest originahty and is certainly not a work refiecting sustained effort. The happenstance that a skilled writer describes a fact in words slightly unore quirky and less pedestrian than the rest of us might use should not convert what is mainly a factual statement about Salinger's attitude toward a person into copyrighted work. At the very least it should be fair to quote it.

229. Id. at 95 . 
The Court begins its discussion of fair use by considering the application of the doctrine to unpublished works. The Court observes that "fair use traditionally was not recognized as a defense to charges of copying from an author's as yet unpublished works," but that this "absolute rule" was "tempered in practice by the equitable nature of the fair use doctrine." The Court notes that, under the Copyright Revision Act of 1976, all of the rights protected by copyright, including the right of first publication, are subject to fair use, but explicitly rejects the contention, advanced by The Nation, that Congress "intended that fair use would apply in pari materia to published and unpublished works." "Under ordinary circumstances," the Court states, "the author's right to control the first public appearance of his undisseminated expression will outweigh a claim of fair use." This proposition was emphasized with respect to unpublished letters. Reckoning with The Nation's argument that fair use could permissibly be made of President Ford's unpublished memoirs because the imminent publication demonstrated that the author has no imterest in nonpublication, the Court said, "This argument assumes that the unpublished nature of copyrighted material is ouly relevant to letters or other confidential writings not intended for dissemination," an assumption the Court went on to reject. Pertinent to our case is the fact that the Court underscored the idea that unpublished letters normally enjoy msulation from fair use copying. ${ }^{230}$

This detailed quotation is designed to convince the reader of both the Second Circuit's respect for the Supreme Court's reasoning and its own devotion to precedent.

Interestingly, however, the Second Circuit fails to mclude the sentences immediately succeeding its last quoted sentence from the Harper \& Row opinion. These sentences reveal that the paragraph's thrust does not underscore the idea that unpublished letters are insulated from fair use. Instead, the Court finds that the utilitarian scheme of the Constitution and of the statute must protect cominercial imterests at least as much as common law copyright has protected personal privacy interests. The Nation had argned that any special protection for an unpublished work should pertain to its "confidential" nature, if any, but should not extend to a cominercial interest. ${ }^{231}$ The Court disagreed:

1t is true that common-law copyright was often enlisted in the service of personal privacy. In its cominercial guise, however, an author's right to choose when he will publish is no less deserving of protection. The period encompassing the work's initiation, its

230. Id. (quoting Harper \& Row, Publishers, Inc. v. Nation Enters., 471 U.S. 539, 550-52, 554, 555 (1985)) (emphasis added) (citations omitted).

231. Harper \& Row, Publishers, Inc. v. Nation Enters., 471 U.S. 539, 554-55 (1985). 
preparation, and its grooming for public dissemination is a crucial one for any literary endeavor. The Copyright Act, which accords the copyright owner the "right to control the first public distribution" of his work, echoes the common law's concern that the author or copyright owner retain control throughout this critical stage. The obvious benefit to author and public alike of assuring authors the leisure to develop their ideas free from fear of expropriation outweighs any short-term "news value" to be gained from premature pubhication of the author's expression. The author's control of first public distribution implicates not only his personal interest in creative control but his property interest in exploitation of prepublication rights, which are valuable in themselves and serve as a valuable adjunct to publicity and marketing. Under ordinary circumstances, the author's right to control the first public appearance of his undisseminated expression will outweigh a claim of fair use. ${ }^{232}$

In omitting this paragrapl, the Second Circuit ignores the facts and the ratio decidendi in Harper \& Row, flawed as the latter may be, and derives from the Supreme Court's language a facile litmus test to resolve a very different copyright dispute. The Second Circuit creates a de facto presumption against the fair use of unpublislied materials, undifferentiated with respect to whether the creator intends to publish, will soon publisl, or is unwilling or unlikely to publisli at all. Far from finding a special solicitude for unpublished letters, one could have as logically drawn the opposite inference from the Supreme Court's opinion. The Court's acknowledgement that "[i]t is true" that copyright has been "enlisted" in the service of personal privacy has an odd syntax that certainly does not convey approbation of that enlistment;, ${ }^{233}$ if anything, this language conveys a certain discomfort with the enlistment. Harper \& Row does not readily justify the inference that "unpublished letters normally enjoy insulation from fair use copying."234 Nor does the opinion support the Second Circuit thinking "that the tenor of the Court's entire discussion of unpublished works conveys the idea that such works normally enjoy complete protection against copying any protected expression."235

The Second Circuit invests its careless analysis with an aura of diligence by struggling with the possible meaning of the Supreme Court's

232. Id. (emphasis added) (citations omitted).

233. Id. at 554. The opening, independent clause, "[i]t is true" is a rhetorical device by which the Court concedes the validity of The Nation's factual premise only to deduce in the next sentence a legal conclusion opposite to that asserted by The Nation. The Nation had meant that common law copyright should at most protect privacy interests; the Court concludes that it protected commercial interests even more.

234. Salinger, 811 F.2d at 95 .

235. Id. at 97 . 
statement that the "scope of fair use is narrower" for unpublished works. ${ }^{236}$ While recognizing that the phrase might mean only that a fair use of unpublished material might simply be a smaller amount of use, the Second Circuit purports to find in the "tenor" of the opinion a complete prohibition on such use: 'Narrower 'scope' seems to refer to the diminished likelihood that copying will be fair use when the copyrighted material is unpublished."237 This purported analysis is either laughable or frightening in its failure even to mention a crucial element of the Supreme Court's holding, that The Nation's rush to beat the copyright holder to the market was unfair. ${ }^{238}$

Perhaps the Second Circuit failed to perceive that not all unpublished materials are alike because it was mesmerized by the Supreme Court's rhetorical strategies. At least three different interests underlie the right of first publication: privacy, creative control, and commercial exploitation of prepublication rights. Which is involved in a given case depends on the kind of writing involved and the author's intention in regard to the writing. Had the court acknowledged these various interests, it would have recognized that Harper \& Row had little relevance to the Salinger case. Indeed, such a recognition could have given the court the opportunity to address the real issue: whether Salinger ought to be able to protect his privacy interest in his letters through copyright. Instead, the court glossed over this central issue by finding an inviolable copyright in the material simply because it was unpublished.

Equally unfortunate, the court distorted the analysis of the other fair use factors, especially the amount used factor and the effect of the use on the market for original work factor. As noted above, the court pays no attention to the fundamental question of what exactly is copyrighted, and thus assumes that every quote and paraphrase counts for the amount used factor. ${ }^{239}$ On the inarket effect factor, the court engages in a tenuous distinction between actual and potential market effect, noting that Salinger is entitled to protect his opportunity to sell the letters even though he had expressly disavowed any intention to do so and had sought the injunction to protect his privacy. ${ }^{240}$ Even with this fanciful possibility in mind, the court admits that Hamilton's

book would not displace the market for the letters. Indeed, we think it likely that most of the potential purchasers of a collection of the letters would not be dissuaded by publication of the biography. Yet some impairment of the market seems likely. The biography copies virtually all of the most interesting passages of the letters,

236. Harper \& Row, 471 U.S. at 564.

237. Salinger, 811 F. 2 d at 97.

238. Harper \& Row, 471 U.S. at 562-63, 567.

239. Salinger, 811 F.2d at 97-99.

240. Id. at 99 . 
including several highly expressive insights about writing and literary criticism. Perhaps few readers of the biography would refrain from purchasing a published collection of the letters if they appreciated how imadequately Hamilton's paraphrasing has rendered Salinger's chosen form of expression. The difficulty, however, is that some readers of the book will gain the impression that they are learning from Hamilton what Salinger has written. ${ }^{241}$

As the court admits, this is a Catch-22 for the biographer; what the court fails to realize is that the dilemma cannot be avoided by the court's facile suggestion that the biographer limit himself to the facts. Indeed, the court seems to assume that Hamilton will harm the market for anything Salinger has written by presenting the work in prose less glittering than Salinger's own. Surely, the court does not mean to suggest that a biographer cannot report the fact that a subject conveyed a certain meaning im speech or writing. Yet, the court faults the biographer for prefacing paraphrase with conventional introductions such as, Salinger "said" or "wrote."242 The court fails to understand that the intersection of the subject's expression and the subject himself will always pose a problem, especially when the subject has a gift for self-expression. ${ }^{243}$

241. Id. (emphasis added) (footnote omitted). Unwittingly, the Second Circuit here raises an important argument for verbatim quoting: accuracy of not only fact but the impression on a reader's mind. Had the biography not been enjoined, even Salinger might have preferred relatively generous quotation of his own words rather than mediocre paraphrases or unverifiable assertions ahout his character and attitudes.

242. Id.

243. Perhaps in response to widespread criticism, the Second Circuit subsequently engaged in an intra-cameral battie of dicta over the possibility of distinguishing between copyrighted expression and uncopyrightable fact. The majority dismissed an infringennent action concerning unpublished writings of L. Ron Hubbard on laches. New Era Publ'ns Int'1 v. Henry Holt \& Co. (New Era II), 884 F.2d 659 (2d Cir. 1989), denying rehearing of (New Era I), 873 F.2d 576 (2d Cir. 1989); see also New Era Publ'ns Int'l v. Carol Publ'g, 904 F.2d 152 (2d Cir. 1990). Despite that holding, the majority argued with the dissent over the extent to which unpublished expression should simply be immune from fair use. New Era I, 884 F.2d at 661-64.

The dissenters in New Era II, including Judge Newman, the somewhat neful author of the Salinger opinion, were able to perceive the defects in their broad rejection of any use of unpublished materiai. It was now perfectly clear to the dissenters that the biographer needed to quote Hubbard directly in order to demonstrate that Hubbard, the founder of an obscure religious sect was a man of doubtful integrity. New Era II 884 F.2d at 662-64 (Newman, J., dissenting). For reasons the dissenters never make entirely clear, Hubbard's character traits, apparently unlike Salinger's, required "proof' by quotation. Id. The dissenters note that the "problem is whether, even as to unpublished writings, the doctrine of fair use permits some modest copying of an author's expression in those limited circumstances where copying is necessary to report fairly and accurately a fact set forth in the author's writings." Id. at 662 . With a subtlety missing from Salinger the dissenters now recall that "expressive words sometimes need to be copied "im the interest of aecuracy, not piracy." Id. at 663 (quoting Consumers Union v. Gen. Signal Corp., 724 F.2d 1044, 1049 (2d Cir. 1983)). The dissenters "do not believe that biographers and journalists need be apprehensive that this Circuit has ruled against their right to report facts contained in unpublished writings, even if some brief quotation of expressive content is necessary to report those facts accurately." Id.

Although I disagree with the majority on the merits, the majority position was at least consistent. The majority had rcjected a distinction between fact and expression and rejected the dissenters' reliance 


\section{IV}

\section{The Aftermath: Has Fair Use Been "Rescued" After All?}

While the Second Circuit's decision in Salinger vastly restricted the use of unpublished, unlicensed materials, ensuing decisions slowly retreated from that position while endeavoring to clarify the fair use doctrine. ${ }^{244}$ The Second Circuit itself grudgingly retreated from its near ban on the use of unpublished materials, permitting de minimis quotation of unpublished letters and journals in a scholarly biography of author Richard Wright. ${ }^{245}$ With refreshing candor and insight, Judge Van Graafeiland wrote a concurring opinion, finally distinguishing Harper \& Row on its facts. He also questioned whether the quoted expressions should even be eligible for copyright. ${ }^{246}$

After prodding from Congress im 1992, ${ }^{247}$ subsequent decisions abandoned the presumption against use of unpublished materials while

on pre-Harper \& Row authority. Id. at 660-61. In repudiating the district court's reasoning, the majority in New Era I noted,

[t]he district court sees a significant distinction in purpose between the use of an author's words to display the distinctiveness of his writing style and the use of an author's words to make a point about his character, finding far greater justification in the latter than in the former. We find such a distinction unnecessary and unwarranted in applying the statutory fair use purpose factor.

New Era I, 873 F.2d at 583. The majority not only relies on Harper \& Row to conclude that use of unpublished material is rarely fair even if the goal is to establish a fact, but also finds that Harper \& Row overrules the earlier Second Circuit decision upon which the dissenters rely.

[1]n light of the reversal by the Supreme Court of our Harper \& Row decision, the following in Consumers Union turned out to be an incorrect statement of the law: "Implicit in that decision [Second Circuit decision in Harper \& Row] is an acknowledgement that, where accurate reporting requires use of verbatim quotations, fair use will be liberally applied. ..." It now can be said that fair use is never to be liberally applied to unpublished copyrighted material.

New Era II, 884 F.2d at 661 (Miner, J., concurring). Neither the majority nor the dissenters in New Era II effectively analyze the facts or the equities. The dissent attempts to minimize its embarrassment over Salinger by pointing out that Hamilton's quotes enlivened the text, but they make no effort to explain why that, alone, should dictate the outcome. Id. at 663 .

244. See cases cited infra note 248.

245. Wright v. Wamer Books, Inc., 953 F.2d 731 (2d Cir. 1991). The discussion of factor two, the "nature of the copyrighted work," is grudging in its insistence on correcting the district court's reasoning. Id. at 737-38. The district court had rested its conclusion that the use was fair on three grounds: 1) that the biographer had paraphrased rather than quoted; 2) the paraphrase involved factual reportage; and 3) the subject's privacy was not implicated because he was dead. Id. at 737. The Second Circuit insisted that these reasons were "not relevant to factor two." Id. at 738. In other words, the fact that a work was unpublished was simply an unassailable factor bearing against fair use. Astoundingly, the Court even commented that "whether the use implicates the author's privacy interests or not" has "no bearing on factor two." Id. This last comment either reflects the Second Circuit's belief in the Supreme Court's and its own overt utilitarian rationales in cases like Harper \& Row and Salinger or it represents an attempt to deny, in reaction to criticism of the Salinger decision, that the earlier decision in Salinger had, in fact, been motivated more by concern for Salinger's privacy than for his commereial incentives.

246. Id. at 743 (Van Graafeiland, J., concurring).

247. Congress amended section 107 to make explicit that a work's unpublished status is just one factor in evaluating fair use. See supra note 51 and accompanying text. The legislative history suggests 
preserving strict limits on the purpose for and the amount of the use. ${ }^{248}$ No subsequent court has confronted a case where the equitable considerations were as difficult as they were in Harper \& Row or in Salinger, nor has any court engaged in a serious analysis of the type of expression that should be protected by copyright or the extent to which the author's privacy should be relevant.

While the post-Salinger approach to the fair use of unpublished materials is substantially inore liberal, many factors remain unresolved. A conventional synthesis of appellate decisions on the fair use of unpublished materials since passage of the Copyright Act of 1976 yields something like the following rule: although the fact that expression is unpublished always weighs against the fairness of its use, a user may nonetheless copy without permission modest amounts of unpublished copyrighted expression provided that (1) the user's principal purpose and effect is to establish a fact (including the character of the original author), (2) the use does not seem likely to enhance the commercial appeal of the second work, and (3) the use does not reduce the actual or potential market for the original expression, or the market for an actual or potential larger work in which the original expression is, or might be, incorporated, either by acting as a market substitute for the copied expression or the larger work, if there is a market, or by revealing the "heart" of the larger work. ${ }^{249}$ The issues I have considered above: the definition of "work of authorship" and the relevance of the author's personal interests in privacy, creativity, and

that Congress wished to assure the Second Circuit that the Wright decision was right. H.R. REP. No. 102-836, at 8 (1992).

248. E.g., Norse v. Henry Holt \& Co., 991 F.2d 563 (9th Cir. 1993) (permitting use of small, but vivid, quotes from beat poet Norse's letters in a "scholarly" biography of another beat writer, William S. Burroughs); Religious Tech. Ctr. v. Lerma, 908 F. Supp. 1362 (E.D. Va. 1995) (denying an injunction against Washington Post for publishing minimal excerpts received over the Internet); Religious Tech. Ctr. v. Lerma, 897 F. Supp. 260 (E.D. Va. 1995) (finding that the nature of the unpublished court materials is not dispositive); Religious Tech. Ctr. v. Netcom On-Line Communication Servs., Inc., 907 F. Supp. 1361 (N.D. Cal. 1995) (denying an injunction against the computer bulletin board and finding that the precise nature of the work, whether published or unpublished, was not important to fair use consideration because it dealt with Internet postings); Lish v. Harper's Magazine Found., 807 F. Supp. 1090 (S.D.N.Y. 1992) (holding that Harper's infringed writer/celebrity Gordon Lish's copyright in a letter to students by quoting large portions of it without comment; but awarding only nominal damages). But cf. Religious Tech. Ctr. v. Lerma, 1996 U.S. Dist. Lexis 15454 (E.D.Va. 1996) (awarding statutory damages agamst a disaffected church member who had transmitted substantial documents over the Internet); Religious Tech. Ctr. v. Netcom On-Line Communication Servs., Inc., 923 F. Supp. 1231 (N.D. Cal. 1995) (enjoinimg future unauthorized copying by an individual). The Religious Technology Center cases all involved efforts to enjoin publication of L. Ron Hubbard's unpublished works. The results varied, depending on the copier's motivation (that is, personal animosity versus journalistic reporting) and the extent of the copying. The post-Salinger cases are usefully discussed in two student notes. Benjamin Ely Marks, Note, Copyright Protections, Privacy Rights, and the Fair Use Doctrine: The Post-Salinger Decade Reconsidered, 72 N.Y.U. L. REv. 1376 (1997); Robert Spoo, Cominent, Fair Use of Unpublished Works: Scholarly Research and Copyright Case Law Since 1992, 34 TuLSA L. J. 183 (1998).

249. A larger work might be a memoir or a collection of letters, for exainple. 
autonomy remain unresolved. Given these unresolved issues, the current doctrinal approach all but guarantees that publishing coinpanies will continue to adhere to a Salinger-like ban on the use of unpublished materials.

Several commentators now advocate a distinction between types of unpublished expression, agreeing with the Supreme Court that fair use should rarely, if ever, apply to works, such as manuscripts, drafted for possible publication. These commentators suggest more liberal use of other kinds of expression, like letters, not generally written for publication. ${ }^{250}$ Asserting that the copyright statute is chiefly utilitarian in purpose, they argue that the exclusive right should not be greater than necessary to motivate the creation and dissemmation of original work. They accept the rationale that selecting, revising, and editing expression for publication serves the public interest and that writers and publishers, who devote time and effort to that work, should be assured of compensation by an exclusive right of first publication. ${ }^{251}$ In contrast, they argue that the right of first publication should not be so exclusive where the copyright holder did not write for publication and does not intend to dissemmate the material. While acknowledging that the original author may have other legitimate interests, such as privacy, these commentators argue that the copyright statute should not be used to protect such non-pecuniary interests. ${ }^{252}$ In this view, the holder of copyright would enjoy a presumption against the fairness of any copying until first publication of expression drafted with a view to publication or other financial exploitation; expression composed without the goal of publication would be subject to more liberal fair use, presumably comparable to that afforded published materials..$^{253}$

250. E.g., Fisher, supra note 52, at 1773-74 (recognizing a legitimate copyright interest in protecting the creative process by preventing premature disclosure of a work-im-progress); Gordon, supra note 117, at 1632-35 (recognizing a right to keep truly private works such as undisclosed diaries, but generally allowing fair use where the defendant simply wants to keep some imformation from the public); Leval, supra note 38, at 1119 (arguing that copyright should not protect non-economic interests in non-dissemination of copyrighted expression, that copyright's "central concern is for the protection of material conceived with a view to publication, not of private memos and confidential communications," and characterizing as "bizarre and contradictory" a conclusion that such private communications "should receive more vigorous protection than the writings that copyright was conceived to protect'); Marks, supra note 248, at 1392-94 (arguing in part that copyright protection for privacy should cease at the author's death); Jon O. Newman, Copyright Law and the Protection of Privacy, 12 Colum.-VLA J.L. \& ARTs 459, 464, 469 (1988) (arguing that copyright should protect "the products of people's minds" even when committed to paper and made available to friends, but noting that American law generally only protects such an interest when it is tied to a commercial interest in expression). Cf. Weinreb, supra note 16 at $1145-46$ (arguing that it is counter-intuitive to permit greater use of materials never intended for publication).

251. See Harper \& Row, Publishers, Inc. v. Nation Enters., 471 U.S. 539 (1985).

252. E.g., GoLdSTEIN, supra note 124; Leval, supra note 38, at 1117.

253. An obvious difficulty with this distinction is determining the author's intent at the time of composition. Letters may be an example of expression composed without thought of publieation. As an individual ages and perhaps acquires a public reputation, however, it may occur to him that the letters 
While this position seems like a reasonable alternative to advocating that every bit of prose be licensed until seventy years after a writer's death, its logic is questionable and its practical application impossible. The utilitarian logic arguably requires a more extreme conclusion: statutory copyright should not subsist at all in expression that would have been created without the copyright incentive. ${ }^{254}$ The statute's terms, however, do not expressly limit the grant of copyright to works made in contemplation of any copyright incentive. ${ }^{255}$ Moreover, this position ouly partially solves the probleun in a case like Salinger. It needs, in addition, a careful definition of "work of authorship," a sophisticated recognition that, at some level, all expression conveys fact and is itself artifact, and a pragmatic understanding that gross invasions of an author's privacy will always distort fair use analysis if judges continue to deny that privacy concerns influenced their analyses.

The quest to distingnish among types of unpublished materials is a back-door effort to define what "works" should be protected by copyright. As noted above, the 1976 Act conferred copyright automatically upon fixation of the expression. The 1909 Act's prerequisites of publication or registration had required an author to affirmatively pursue statutory protection. In enacting the 1976 Act, Congress abandoned those prerequisites in part to simplify the calculation of the copyright term by keying the copyright term to the author's hife rather than to the creation or publication of the work. ${ }^{256} \mathrm{~A}$ consequence of this statutory change was that expression of a quantity and quality that an author would have neither published nor registered under the 1909 Act would now be presumptively copyrighted. As a

might be compiled for publication. Like Salinger, the author may suddenly perceive, or at least allege, the literary value of old expression when someone else decides to copy it. Even if the author's real interest is to preserve privacy, an attomey might counsel him not to rest an infringement action on that claim alone, but to also argue that he or his heirs might consider publishing the material at some later date. Cf. Crews, supra note 15.

254. A utilitarian might avoid the problem by ârguing that the fair use defense is simply a more efficient mechanism for determining copyright. If one assumes that most expression will not be worth copying, regardless of what inspired its creation, then it would arguably be cheaper to presume copyright and lcave to the relatively occasional user the burden of proving, in essence, that the material does not merit exclusive rights. This las the advantage of rewarding the "accidental" author who writes without thought of financial exploitation but discovers that there is, in fact, a market for the work. While this somewhat himits public aecess, it may contribute to a cultural, if not individual, expectation that creative effort will be honored and, if successful, rewarded at least some time im the future. In this respect, the cultural expectations of serious literary entrepreneurs may be analogized to that of longterm investors im the stock market, whose resolution, steadfastnessness, and long-term perspective are rewarded. A little luck will also lielp. Therefore, a utilitarian could argue that the statute supports a cultural incentive for crcation regardless of whether the individual creator is conscious of that incentive, just as tax, and other, economic regulations support a cultural incentive for eapital investment.

255. Section 102(a) provides that "[c]opyright protection subsists . . . in original works of authorship fixed in any tangible medium of expression." 17 U.S.C. \$ 102(a) (1994).

256. See Notes of Committee on the Judiciary, H.R. REP. No. 94-1476, reprinted in notes to 17 U.S.C. $\S 301$. Another reason for the cliange was to facilitate international copyright agreements. See H.R. REP. No. 94-1476, at 52-54 (1976). 
result, the types of material subject to statutory presumptions and remedies are now much more numerous. Arguably, it is this transfer from the vagaries of common law copyright to statutory copyright of much "incidental" expression that motivates these commentators' quest for a principled basis upon which to distinguish among types of unpublislied materials.

Unfortunately, it is difficult to determine whether a writer was Inotivated by copyright possibilities when creating a particular expression. There are numerous considerations: How significant must be the prospect of financial exploitation? Sliould a poet who composes a poem knowing that the poem may never be publislied, much less generate income, be barred from statutory copyright for the poem? Should an erudite letterwriter enjoy less protection merely because her principal purpose was to correspond with a friend? Should the determination of motivation be entirely subjective or partially objective? When should the determination be made?

Commentators seem to agree that some objective measure of the author's motivations can be inferred retrospectively from the genre of the expression, sucl as a personal letter, or from the passage of time without revision or publication. However, that view fails to account for material that the author did not initially intend to publish but that nonetheless becomes valuable. ${ }^{257}$ if the degree of protection depends on the writer's subjective intent, how and when should the intent be assessed? Is it realistic to think that every writer forms an intent about publication at the time of creation? What if a successful writer is urged to publish juvenilia that he had not thought to publisl before becommg famous? And, as a practical matter, what evidence could be adduced to refute a writer's assertion of an intent to exploit the work as soon as she learns of a proposed use?

A. The More Things Change, the More They Stay the Same: Sundeman v. Seajay Society

The latest appellate decision on unpublished materials amply illustrates the inadequacy of the attempt to distinguish unpublished materials based on retrospective conjccture about the author's intentions at the time of writing, and casts significant doubt on Judge Leval's optimism that fair use has been "rescued" by the Supreme Court decision im Campbell v. Acuff-Rose Music, Inc. ${ }^{258}$ In Sundeman v. Seajay Society, ${ }^{259}$ the only circuit decision since Harper \& Row to deal with an unpublished

257. Examples include the letters written by an elected official in a clandestine love affair after the affair is discovered, or the early papers of a writer who becomes famous for other writings.

258. Leval, supra note 60.

259. 142 F.3d 194 (4th Cir. 1998). 
manuscript, the Fourth Circuit permitted the Society and a scholar in its employ to copy an entire manuscript of an unpublisled novel for archival and scholarly examination. The court also permitted the scholar to use substantial quotes and paraphrases of the manuscript im a paper that was orally delivered to about 200 people. ${ }^{260}$ The manuscript, a draft novel by Marjorie Rawlings, author of The Yearling, had been written many years earlier and had never been published. When Rawlings died, her will designated one of lier closest friends, Julia Bigham, as literary executor; Bigham managed her papers, apparently diligently. Rawlings' widower and executor of her estate, Norton Baskin, became aware of the manuscript only after Bigham died and her daughter discovered the manuscript. ${ }^{261}$ Bigham's daughter sold the manuscript to a rare book dealer, who in turn sold it to the Seajay Foundation, whicl in turn approached Baskin and the University of Florida to verify its authorship. ${ }^{262}$

The Fourth Circuit bows ritually to the presumption against fair use of unpublished material but quickly distinguishes Harper \& Row on the facts. The court notes in particular the absence of any damage to the market for the unpublished manuscript. ${ }^{263}$ Instead, it relies on langnage in Campbell $v$. Acuff-Rose Music, Inc. to hold that the Foundation and scholar's use was "transformative."264 It concludes that the indisputably substantial uses were fair. ${ }^{265}$

On one level, Sundeman seems to bring appropriate closure to the confusion wrought by Harper \& Row and Salinger. The Sundeman decision clarifies that the unpublished status of the manuscript is not determinative, and instead focuses on the competitive impact of the use. In Harper \& Row, the Court had found a nieasurable impact: $\$ 12,500$ cancellation of first serial contract; in Sundeman, the court found none. Neither case nivolved the privacy issue in Salinger. Ford was a public

260. Id. at 199.

261. The Court held, in part, that Baskin's effort to recover physical possession of the manuscript was time-barred. Id. at 201. Although his copyright was not affected by that holding, the court's opinion suggests that Baskin's lassitude in pursuing the manuscript tipped the equities against him in the fair use portion of the dispute. See id. at 201.

262. Id. at 197-99.

263. Id. at 206-07.

264. Id. at 202-03.

265. The court's distinction that the paper was not to be published unless the necessary permission was secured is not relevant in accepted copyright doctrine. If the use in the oral presentation was fair, then no permission should be necessary for the performance or the print publication. Although the court's conclusion is reasonable, it imples that otherwise infringing uses are fair so long as no one nuakes any money from them or so long as the publication is modest. There is no precedent for this appealing view, which would surely shelter most academic articles from infringement claims. To accept this view is to elevate to determinative significance the lack of a commercial impact under the fourth factor. Since the Supreme Court roundly criticized the Court of Appeals for having unduly elevated commencial purpose to dispositive effect in Campbell, 510 U.S. 569, 583-84 (1994), it seems unlikely that any court will soon follow the Fourth Circnit's lcad and treat the lack of commercial purpose or effect as dispositive without regard to other factors. 
figure intending to publish the material; Rawlings was long dead and her literary executor had, one might infer, decided that the manuscript was neither worthy of publication nor deserving of destruction.

Unexceptionable as the judgment may seem, Sundeman refiects a familiar preference for facile reliance on dicta, "transformative use" in this case, over careful analysis. A draft novel is without doubt a "work" entitled to copyright protection. Yet, by permitting nearly two verbatim copies and very substantial quotation and paraphrase in a paper, the court basically abrogated the copyright before its term. While the court's rationalization seems right because the use was scholarly and appears to have neither damaged the financial interests of the copyright holder nor enhanced those of the user, the fact remains that the copyright holder objected to the use, be it for personal, aesthetic or financial reasons.

The court's analysis ignores a potentially serious issue that has both utilitarian and personal implications, particularly when the author is still living. The psychological comfort of guaranteed "exclusivity" or "privacy" for drafts may shield the creator's missteps, juvenilia, and the like from public view, regardless of whether he intends to publish and perhaps, precisely because he does not. The utilitarian argument would be that a zone of privacy facilitates creation. The personal argument would be the one inade in Harper \& Row: the revelation of earlier drafts undermines the incentive to polish the work because the creator's presentation of self in the coinpleted published manuscript is the "work," the expression of self that she presents to the public. In this respect, a never-to-be-published draft should be as protected as a soon-to-be-published one.

Of course, the threat to creativity or privacy, for lack of more precise terms, diminishes after the creator's death, although it is conceivable that some creators would be perturbed even by the possibihty of posthumous revelations. A creator so haunted may best prevent access by destroying drafts. While not an outcome that biographers and historians would welcome, it might nonetheless be preferable to the demise of fair use. The point is that any relaxation of copyright protection for works squarely within the statute's purpose should be carefully analyzed for their potential incentives on creation or destruction. It is unfortunate that the Sundeman court did not even pause to consider the possible impact of its decision on creators' sense of control over the time and form in which to present their expression. Oddly enough, the linchpin of Harper \& Row's successful argument for a truly exclusive right of first publication has disappeared from the analysis of a case where it was certainly relevant, a case dealing with the use of an unpublished draft novel.

After Sundeman, one could offer an alternative synthesis for fair use of unpublished materials, ${ }^{266}$ one with quite a different

266. See supra text accompanying note 249 for the "conventional" synthesis. 
emphasis: (1) copying of substantial amounts of unpublished manuscripts of long-dead authors for scholarly articles and presentations is fair, at least if the scliolar does not make any money; ${ }^{267}$ (2) copying of small excerpts of correspondence, journals, diaries and the like of dead authors may be deemed fair, provided that the excerpts are not intrinsically interesting to read either for style or for revelations of idiosyncratic behavior, attitudes, or relationships, ${ }^{268}$ although such revelatory excerpts may be fair if the excerpts arguably demonstrate that the writer was disreputable or dishonest; ${ }^{269}$ (3) no copying of manuscripts, correspondence or other writings of a living author is fair use, ${ }^{270}$ with possible exceptions for the writings of public officials on matters of urgent public concern that are not otherwise likely to be published ${ }^{271}$ or the writings of beatniks. ${ }^{272}$

The alternative synthesis differs froin the conventional one im two major respects. The conventional synthesis accords to the second fair use factor, the nature of the original copyrighted expression, an overriding significance. Essentially, it sets up a rebuttable presumption against the use of unpublished materials. The balance of the conventional synthesis basically tracks the other three fair use factors; with an added non-statutory requirement that the use not be too beneficial, at least financially, to the user. The alternative synthesis does not accord a presumptive weight to the fact that materials are unpublished; it simply begins witl that fact. Instead, the second synthesis expressly differentiates among uses of unpublished materials according to their probable impact on the market for the materials and the foreseeable impact on the creative control or privacy interests of the orignial creator. The alternative synthesis accounts better for the judginents courts have actually reaclied in these cases; it does so by highlighting the proprietary and personality interests at stake. This synthesis is frank, and does not suppress utilitarian or rights-based principle of copyright for the sake of the other. It does not remove the conflict between the two principles, but by making thein explicit it clears the fog of rhetoric generated by courts' and scholars' failure to make their choices openly. Except where a use obviously competes in an identifiable

267. Sundeman, 142 F.3d 194.

268. Wright v. Warner Books, Inc., 953 F.2d 731 (2d Cir. 1991).

269. New Era Publ'ns Int'1 v. Carol Publ'g Group, 904 F.2d 152 (2d Cir. 1990); New Era Publ'ns Int'l. v. Henry Holt \& Co., 873 F.2d 576 (2d Cir.), reh'g denied, 884 F.2d 659 (2d Cir. 1989).

270. E.g., Salinger v. Random House, Inc., 811 F.2d 90 (2d Cir. 1987). But cf. Norse v. Henry Holt \& Co., 991 F.2d 563 (9th Cir. 1993), on remand, 847 F. Supp. 142 (N.D. Cal. 1994) (permitting use of small, but vivid, quotes from beat poet Norse's letters in a scholarly biography of another beat poet).

271. See Harper \& Row, Publishers, Inc. v. Nation Enters., 471 U.S. 539, 555-60 (1985).

272. Norse, 991 F.2d 563. My equation of public officials and beatniks is only partly tongue-mcheek. The equation underscores the absence of coherent principle in applying fair use and to support my argument that courts necessarily make value judgments about the value of works and the status of their authors. 
market for the soon-to-be-published expression, the holdings are more readily reconciled in terms of unjust enrichment and some sort of personal interest loosely related to privacy.

The courts' reluctance to be candid about these considerations generates confusion, dependence upon abstractions, and concomitant argument based on dicta rather than on holding. Although dicta from Harper \& Row and Salinger dominate the courts' discussions, those seminal cases are in reality the outliers. Harper \& Row is readily distinguishable from the inajority of cases on two grounds: the demonstrable market impact of the defendants' use on the copyright holder's market for a derivative of the original memoir, and the fact that the copied document was not just unpublished, but soon-to-be-published. Salinger involved the Second Circuit's reaction to dicta in Harper \& Row, dicta that has become more suspect with time. In addition, as others have commented, Salinger involved a very marked privacy concern, even though it is doubtful that it should have strengthened the copyright in the absence of careful analysis. Salinger does show, however, an implicit judicial concern with the conduct and particularly the market savvy of the defendant publisher and the biographer user. The Second Circuit's emphasis on the fact that quotes or paraphrases of Salinger's letters appeared on forty percent of the biography's 192 pages even after substantial cutting from an earlier draft and the remark that the letters made the book "worth reading"273 indicates a judicial suspicion that Hamilton's biography was likely to be successful because Salinger's acerbic expression was made all the more inarketable by Salinger's attempt to seclude himself.

Sundeman and Salinger are best reconciled on this basis: the assessment of fairness depends less on the four statutory factors than on the court's assessment of the market for the using work. The more marketable the using work, the less likely that the use will be fair. ${ }^{274}$ The Fourth Circuit's opmion in Sundeman reflects progress. In particular, unlike the Second Circuit's opinion in Wright, ${ }^{275}$ the Sundeman opimion does not regard the unpublished nature of the work as determinative of fair use. Unfortunately, however, the court's discussion of the nature of the copyrighted work is cursory, distinguishing Harper \& Row solely on the basis that supplanting the copyright holder's right to publish was neither the intention behmi nor the effect of the Seajay Society's use. ${ }^{276}$ The court

273. Sundeman v. Seajay Soc'y, Inc., 142 F.3d 194, 204-05 (4th Cir. 1998).

274. Note that this is not the same as the fourth factor under section 107 because it is independent of whether the using work will impact the market for the original work. See 17 U.S.C. $\$ 107$ (1994).

275. Wright v. Warner Brothers, Inc., 953 F.2d 731, 736-37 (2d Cir. 1991).

276. Sundeman, 142 F.3d at 204-05. 
does not even mention the issue of an author's creative control or the right "not to publish at all."277

\section{B. Campbell v. Acuff-Rose Music, Inc.}

However unfortunate past decisions may have been, the Supreme Court's poimted criticism of the lower court's careless reliance on dicta in Campbell v. Acuff-Rose Music, Inc. ${ }^{278}$ generates some hope that the Supreme Court will direct the lower courts from bad habits. ${ }^{279}$ The more doubtful question is whether the Court has indeed provided a useable alternative analysis or whether the lower courts agam succumb to the temptation of decision by dicta. Unfortunately, the Fourth Circuit's opinion in Sundeman is troubling because of the zeal with which the court applies language from Campbell, a case involving commercial parody of a published song, to a dispute over an unpublislied novel.

In reversing the Sixth Circuit judgment that a rap parody infringed the Roy Orbison rock 'n roll oldie "Oh, Pretty Woman," the Campbell Court held that the appeals court had erred in using a presumption against the fairness of a commercial use, and the Supreme Court remanded for further findings on market impact under the fourth statutory factor (market effect). In extensive dicta, the Court analyzed the first fair use factor (purpose of the use) and noted that

[t] he central purpose . . . is to see, in Justice Story's words, whether the new work merely "supersede[s] the objects" of the original creation, or instead adds something new, with a further purpose or different character, altering the first with new expression, meaning, or message; it asks, in other words, whether and to what extent the new work is "transformative." $" 280$

The Court concludes by noting that "the more transformative the new work, the less will be the significance of other factors, like commercialism."281

Later in dicta, in discussing the third factor (amount of the use), the Court attempts to discount now inconvenient dicta from Harper \& Row that had criticized The Nation for taking the "heart" of Ford's memoir. ${ }^{282}$ The Court explains that a parodist may need to copy the signature elements

277. Cf. Harper \& Row, Publishers, Inc. v. Nation Enters., 471 U.S. 539, 555-60 (1985) (discussing the "right to refrain froin speaking at all" as support for a strong right of first publication in the author (quoting Wooley v. Maynard, 430 U.S. 705, 714 (1977)).

278. 510 U.S. 569, 585 (1994).

279. Souter's opinion roundly criticized the Sixth Circuit for cutting short the fair use analysis by giving presumptive weight to the fact that the use was commercial. Id. at 585 ("The Court of Appeals's elevation of one sentence from Sony to a per se rule thus runs as much counter to Sony itself as to the long common law tradition of fair use adjudication.").

280. Id. at 579 (citations omitted).

281. Id.

282. Id. at 587. 
of the original, for "it is the heart at which the parody takes aim."283 The Court explains that "[p]arody presents a difficult case," noting that parody inust be able to "conjure up' at least enough of that original to make the object of its critical wit recognizable."284 The Court also distinguishes as unfair "commentary [that] has no critical bearing on the substance or style of the original composition, which the alleged infringer merely uses to get attention or to avoid the drudgery in working up something fresh."285

The question remains whether Campbell's explanation of fair use in parody will prove to be a more reliable guide than earlier explanations, or whether the language on "transformative use" will be misunderstood, overinterpreted, and misused as was earlier dicta about presumptions against commerciality or against use of unpublished materials. ${ }^{286}$ Judge Leval feels reassured that the Supreme Court has rescued fair use in part because of Justice Souter's adoption of Leval's dictum that fair use should extend to "transformative" works. ${ }^{287}$ While Justice Souter's rebuke for the misuse of dicta is salutary, I very much doubt that this new language will provide any more definitive guidance unless the courts invest "transformative" with a common law meaning built from holdings. ${ }^{288}$

283. Id. at 588. This is a particularly dramatic instance of dicta, in which the Court itself avoids an apparent principle froin one case by quoting the same metaphor ("heart") in another context to discredit the principle.

284. Id.

285. Id. at 580 .

286. "Transformative" is a complex signifier. Both the adjective and its root verb, transform, have transitive and intransitive usage. THE OXFORD ENGLISH DictionaRY defines "transformative" as "[h]aving the faculty of transforming; fitted or tending to transform." 18 THE OXFORD ENGLISH DICTIONARY 401 (2d ed. 1989). A 1671 example provided by the dictionary aptly illustrates the ambignity: "The Light of Christ is powerfully Transformative of its Subjects." Id. Does the Light of Christ transform the subjects as viewed by a witness, or does it effect an internal change? Similarly, the roct verb may be transitive, meaning "To change the form of; to change into another shape or form; to metamorphose." Id. at 399. Equally, in intransitive mode, it means "To change in character or condition, to alter in function or nature." Id. The question for fair use is what must be transformed? The original work? The audience for the old work, or the audience for the new work? Or is the idea that the user must work, transforming the copied material into a new genre, a new meaning? The latter would be consistent with a Lockean labor theory and with Romantic notions of authorship. See Woodmansee \& Jaszi, supra note 91, at 772-73 (describing the decline of the "intellectual commons" in favor of increased protections advocated by, among others, William Wordsworth, a leading Romantic).

Does a "transformative" use transform the original in the eyes of the beholder, so that "Oh, Pretty Woman," as the object of the parody, is "transformed" into something laughable, jejune, sexist, naive? Has the original been transformed or has the audience's understanding of the original heen transformed? Ultimately, it seems to me that the Court probably intended that the work should inform, if not transform, the audience for the new work. That usage would be in keeping with long-standing utilitarian copyright doctrine that the statute should be interpreted to increase the public's access to information. For expressive works, then, the test might be whether the new use provides some significant information beyond that which would be available had the copyright holder published the original himself.

287. Campbell v. Acuff-Rose Music, hrc., 510 U.S. 569, 579 (1994).

288. Even subsequent decisions on parody are difficult to reconcile. For example, the Second Circuit felt sure that the use of a near total copy of an Annie Liebovitz phctograph of nude, pregnant Demi Moore in a movie advertisement was a fair use because the substitntion of a male actor's face for 
On the other hand, Campbell does hold out some hope for defining the inchoate difference between a "chiseler"289 and a legitimate user, between a thief and a wise man. One could argue that, beneath all the rhetoric, the holdings of the earlier cases can be rationalized under Campbell. For example, arguably the "unfairness" in Harper \& Row, Salinger, and Lish $v$. Harper's Magazine Foundation, ${ }^{290}$ cases in which the copyright holder prevailed, was that the copyrighted material significantly enhanced the potential market for the second work without adding new value beyond making the original work available sooner. In Harper \& Row, Justice O'Connor noted that the 300 words taken from President Ford's manuscript constituted the "heart" of the manuscript as well as occupying ten to thirteen percent of The Nation's article. ${ }^{291}$ it may be inferred that

Moore's rendered the advertisement a transformative, parodic use. Leibovitz v. Paramount Pictures Corp., 137 F.3d 109 (2d Cir. 1998). In contrast, the Ninth Circuit held that the use of the Dr. Seuss character with characteristic doggerel to lampoon the O.J. Simpson murder trial was not a fair use, as it did not "target" Dr. Seuss's works but merely used the work as a vehicle for getting attention. Dr. Seuss Enterprises, L.P. v. Penguin Books USA, Inc., 109 F.3d 1394 (9th Cir. 1997), cert. denied, Penguin Books USA, Inc. v. Dr. Seuss Enterprises, L.P., 521 U.S. 1146 (1997). While it is true that Paramount's ad may have lampooned Leibovitz's photograph, it is also true that Paramount's primcipal motivation was to use the photograph as a vehicle for getting attention for its movie. The distinction echoes the Second Circuit's distaste for Hamilton's quotations of Salinger because they "enlivened" the former's text. Still, the distinction between "targeting" a work or a subject and "getting attention" for one's own work remains subtle, or perhaps just unclear. One thing is clear. these considerations lie far outside the text of section 107. Moreover, a finding of infringement and issuance of an injunction in Dr. Seuss Enterprises suppressed the work altogether, even though a given parody might well present a borderline case for transformative use. For a recent discussion of Dr. Seuss Enterprises, noting that the availability of injunctive relief can be used to deprive the public of any access to useful, if partially infringing, derivative works, see Alex Kozinski \& Christopher Newman, What's So Fair About Fair Use?, 46 J. CopYricht Soc'y 513 (1999).

One significant issue is whether parody, a classic example of "market failure," see Gordon, supra note 117; William F. Patry \& Shira Perlmutter, Fair Use Misconstrued: Profit, Presumptions, and Parody, 11 CARDozo ARTS \& ENT. LJ. 667, 685-87 (1993), cited in Campbell, 510 U.S. at 578, is analogous to use of unpublished materials. The object of parody may generally refuse to license, as was the case in Campbell. It is less clear whether the holder of copyright on unpublished materials will always be so reluctant. In the case where the holder does, or would refuse to license, one can draw some useful analogies between a parodist's and a biographer's or historian's need to copy. One could argue that in certain works of biography or history, the user has a legitimate need for, and the public has a legitimate interest in, accuracy, about facts, the nature of a person's character, or in the case of a writer, the nature of his style. By analogy to the parodist's need to conjure up the target of his wit, the biographer must conjure enough of his subject's expression to validate a thesis. If this analogy is apt, the subject's personal objection to the use should matter no more than the objection by the parody's target. Presumably, this is the sense in which Leval finds the Campbell dicta appealing.

But the analogy is not quite right when applied to unpublished works for it overlooks the fact that the holder's refusal to license may reflect interests in privacy and creative control that parody does not threaten because, by definition, the target of parody will already be familiar to the public.

289. The Harper \& Row majority quoted the noun, chiseler, im a way suggesting that it accurately described The Nation (or perhaps its editor). Harper \& Row, Publishers, Inc. v. Nation Enters., 471 U.S. 539, 563 (1985).

290. 807 F. Supp. 1090 (S.D.N.Y. 1992) (verbatim reprint, without comment, of a celebrity's letter to his students).

291. Harper \& Row, 471 U.S. at 548, 565 (1985). 
"but for" the Ford quotes, The Nation would have had a mediocre article. In Salinger, the Second Circuit was distressed that the quotes and paraphrases of Salinger's letters "enlivened" the Hamilton biography and to a substantial extent "made it worth reading." forty percent of the biography's 192 pages contained quotes or paraphrases. While it would be patently absurd to limit fair use only to material that was not enlivening, ${ }^{293}$ perhaps Hamilton's biography failed to do much more than present a lively character in his own lively terms, a presentation Salinger could have effected himself had he so chosen. ${ }^{294}$ So, one might infer that the court found that Hamilton did not use the letters to illustrate the writer's life or character, or to provide accuracy and credibility to the account, but to tap a market in readers curious to look into a famously private person's life.

The vice in Salinger, then, was that too much of the value of the second work was attributable to the original writer's expression ${ }^{295}$ and that Hamilton had not contributed enough original msight or analysis. ${ }^{296}$ In a sense, like the later Dr. Seuss case, the problem here was that the used expression was not itself the "target" of Hamilton's inquiry but a tool to attract attention and enhance his sales. ${ }^{297}$ In Lish, the court held that Harper's Magazine infringed writer-celebrity Gordon Lish's copyright in a letter to students by quoting large portions without any comment. ${ }^{298}$ The

292. Salinger v. Random House, Inc., 811 F.2d 90, 99 (2d Cir. 1987).

293. See Sundeman, 142 F.3d at 205-06, for the idea that any quoted expression will by defimition be the "heart" of the work. The Fourth Circuit may have overstated its point, relying on the convenient, if not precise, dicta from Harper \& Row about taking the "heart of a work." Harper \& Row, 471 U.S. at 564-65 (quoting Harper \& Row, Publishers, Inc. v. Nation Enters., 557 F. Supp. 1067, 1072 (S.D.N.Y. 1983)); see supra note 206 and accompanying text. No doubt the Fourth Circuit only intended the more modest point that users will only quote interesting material, and by so doing, will almost necessarily improve the work.

294. Of course, this does not address the public interest in access since Salinger did not so choose.

295. This may always be a problem where the subject is famous for his expressions.

296. Hamilton's own devastating testimony to the effect that he preferred to use Salinger's spicy phrasing, rather than including a mundane summary of his own, did not help. Salinger, 811 F.2d at 97. Some utilitarians rationalize the outcome in Salinger by explaining that some quotations of Salinger's letters were "not justified by a strong transformative secondary objective. The biographers took dazzling passages of the original writing because they made good reading, not because such quotation was vital to demonstrate an objective of the biographer." Leval, supra note 38, at 1112 .

297. This distinction is reminiscent of I. A. Richard's analysis of metaphor, in which he distinginshes between the "tenor" and the "vehicle." I. A. RIChaRDs, THE PHILOSOPHY OF RHETORIC 97-98 (1936). The tenor may be equated with the meaning, or idea; the vehicle with the style or form of expression. In copyright terms Campbell suggests that a user may "target" the tenor of a given vehicle and may use the vehicle to the extent neccssary to make a new tenor. The user may not, however, simply use the vehicle because it is inherently interesting or pleasing. For readers interested in an analysis of judicial use of metaphors in a different doctrinal area, see Haig Bosmajian, The Judiciary's Use of Metaphors, Metonymies and Other Tropes to Give First Amendment Protection to Students and Teachers, 15 J.L. \& EDuc. 439 (1986).

298. Lish v. Harper's Magazine Found., 807 F. Supp. 1090 (S.D.N.Y. 1992). 
vice in these uses is that the audience would not, arguably, understand the meaning of the originals in a new way.

\section{$\mathrm{V}$ \\ SUMMARY}

I have argued that fair use of unpublished materials is unduly restricted by the trade publishing industry to the detriment of the reading public. I have made two central points: 1) too much casual, incidental prose is locked away from quotation by biographers, historians and critics; and 2) reform of the private trade practices cannot occur without new clarity in fair use doctrine.

With respect to the first point, I have suggested that soine of the difficulty biographers and historians encounter $m$ attempting to use unpublished writings still within the copyright period could be alleviated by investing soine content in the statutory term "works of authorship." Without violence to plain meaning or legislative intent, one can argue that "original works of authorship" should not be conflated with "original expression" as the courts commonly do, but that a working definition requires two additional eleinents. Work implies effort, substantiahity and structure; authorship implies a self-conscious effort to create and to promulgate in keeping with a cultural understanding of "authorship."299

Derived in part from Locke's labor theory of property and partly from Romantic notions of individual creation, the modern statutory term should denote works of soine dehiberate structure and craft. It is not feasible to key fair use to some retrospective assessment of whether the writer initially wrote for profit. The assessment of what constitutes a "work" should be made as objectively as possible after the fact by a reasonable reader, perhaps a reader accustoined to the type of expression in question. ${ }^{300}$ Without this definition, the by-products of a busy, noteworthy life, such as e-mail, are all copyrighted, and scholars, biographers, and historians writing before seventy years after the writer's death face either substantial fees or denial of permission.

This recommendation flies in the face of long-standing judicial reluctance to engage in "value judginents" about the quality of expression. ${ }^{301}$ That purported reluctance is disingenuous. Any judicial

299. See Woodmansee \& Jaszi, supra note 91, at 769-74 (discussing Foucault's analysis of the cultural construct of "authorship," in particular the idea that the numerous writings of an individual over a lifetime may be distinguished from writings attributed to an "author" because the latter is endowed by the culture with a quasi-legal or formal responsibility for the writings). For the original, see Foucault, What is an Author?, in LANGuage, Counter-Memory Practice 113-38 (1977). For accessible discussions of the cultural construct of authorship, see BRAD SHERMAN ET AL., OF AUTHORS AND ORIGINS: EsSAYS ON COPYRIGHT (1994).

300. This suggests that jury trials, a rarity now, would be efficacious.

301. An oft-repcated dictum comes from Justice Holmes: 
determination that an expression is "expressive," original, commonplace, or factual entails a value judgment. Moreover, I detect in the fair use cases a paradox: while refusing to judge the quality of the original expression, the courts evaluate the user's expression, ${ }^{302}$ and sometimes his character. ${ }^{303}$ To determine whether a user has "transformed" the origmal, has added something new entails a value judgment, not only about the nature of the new work, but also about the effort that the user has exerted. I fail to understand why judges who readily assess the propriety of a party's conduct in a criminal matter cannot evaluate the worth of texts, ${ }^{304}$ or at least be explicit about the intellectual, cultural, and market behavior that they find acceptable. Fair use disputes necessarily concern cultural norms and conflicts over those norms as much as, or more than, the factors of section 107. The courts' pretense of value-free judgment reflects anxiety that judges who are frank about valuing "works" and "cultural" acts will be open to charges of elitism. While this charge may often have merit, I fail to understand why it is more disabling to judgment in copyright cases than in other disputes. In fact, as I have suggested above in my alternative synthesis, ${ }^{305}$ one obvious way to reconcile the disparate results in some of these cases is by reference to the relative status of the parties.

Perhaps it was once defensible to refuse evaluation of texts when the statutory rights required some affirmative invocation by the putative author. But now, when the casual scribblings of every politician and celebrity can be automatically copyrighted, the copyright statute potentially operates to afford such individuals an exploitable right based not on literary creation but on by-products of celebrity. The courts should cousider whether the public interest should blithely subsidize an additional exploitable exclusive right for postcards written by Madeleine Albright or Tom Cruise, for example.

$[1] \mathrm{t}$ would be a dangerous undertaking for persons trained only to the law to constitute themselves final judges of the worth of [a work], outside of the narrowest and most obvious limits. At the one extreme, some works of genius would be sure to miss appreciation. Their very novelty would make them repulsive until the public had learned the new language in which their author spoke.

Bleistein v. Donaldson Lithographing Co., 188 U.S. 239, 251 (1903) (finding that circus posters have copyright protection), cited in Campbell v. Acuff-Rose Music, Inc., 510 U.S. 569, 582-83 (1994).

302. See, e.g., Campbell, 510 U.S. at 595-600 (Kennedy, J., concurring) (noting concern about applying some minimal criteria for parody entitled to fair use).

303. See, e.g., id. at 580 (an alleged infringer who copies "to get attention" or "avoid drudgery" will have diminished claims to fair use); Harper \& Row Publishers, Inc. v. Nation Enters., 471 U.S. 539, 562 (1985) ("In evaluating character [of the use] and purpose we cannot ignore The Nation's purpose of scooping ... Time.").

304. See New Era Publ'ns Int'l. v. Henry Holt \& Co., 884 F.2d 659, 661 (2d Cir. 1989) (doubting that the judiciary has the ability to discriminate between fact and expression much less relative value in quoted expression).

305. See supra text accompanying notes 266-272. 
The evaluation is most difficult where the creator's fame was generated by hiterary or artistic ability and production, as was true of J. D. Salinger. Here exists a potential confusion. The value of the life's scribbles exists because of the literary achievement of the creator; the very same scribbles by an unknown engineer would likely hold no interest to the public. At the same time, the hife's scribbles may embody the expressive talent that informs the greater, more deliberately crafted works and thus may be worth reading in their own right. They also may reflect, like drafts, upon the talent and development of the writer. In cases of this kind, the "transformative" standard from Campbell may be of some use. The question would be whether the user was really targeting the particular character of the expression, either to analyze the creator's views or actions or to analyze the style of the expression to reveal a new meaning not visible on its face to the average reader.$^{306} \mathrm{But}$, as a practical matter, under such a standard, many critical, biographical and historical quotes that are now effectively prohibited under private trade practice would be legally and financially feasible. It would be fair to put Eudora Welty's comment about a "horned Jew" in context $\mathrm{m}$ order to reveal her attitudes. 307

The public interest lies in generating expressive works and in preserving access to them. He who seeks to preclude use of expression should have the burden of establishing not only ownership, but also that the expression was crafted, or "worked" upon, or that the author seriously attempted to preserve its confidentiality. If neither is demonstrable, then the creator should not be able retroactively to exclude access by others simply because the "expression" has now acquired some interest or value to others or because the creator would prefer that its content remain relatively unknown. ${ }^{308}$

I have two recommendations for injecting determinacy into fair use $\mathrm{m}$ the hopes that private pubhshers will temper their dracoman fair use policies, at least in response to challenges by new writers with stiffened resolve and the legal mandate. First, the courts should be alert to the possibility that the statutory four-factor paradigin may not deal adequately with non-proprietary imterests, such as personal privacy or creative autonomy. Second, the courts should use the old techniques of common law reasoning to refine the law imcrementally im this difficult area; they should eschew decision by dicta.

306. Obviously, there would be a very fine line here between simply presenting anew what the original writer had already written and adding new meaning or value.

307. See supra note 5 and accompanying text.

308 Of course, the creator or other copyright holders may retain other rights, such as ownership of the physical object and privacy interests, which are not exphicitly part of copyright. My argument does not extend to abrogating those rights where the author has taken appropriate steps to preserve thein. 
I end by offering the following guide for analysis of fair use disputes over unpublished materials: ${ }^{309}$

A. A copyright holder should have the burden of establishing that the expression is "work."

B. The user should have the burden of establishing her need for the use to serve the public's interest in information and new original expression. The need for unlicensed use should not be limited to "market failure" situations where the holder either refuses to license at any price or where transaction costs are prohibitive. The user must show how her use would "transform" a reader's understanding of the original.

C. If the copyright holder claims that the use will impair a market, the copyright holder should have the burden of establishing the existence of the market.

D. The user should have the burden of establishing little or no market impact.

E. If the copyright holder does not claim that the use will impair a market, the copyright holder should have the burden of establishing that the use will "chill" the incentive to create other such works by invading a "zone of privacy" necessary for creation.

F. For expression that does not qualify as a "work," the creator, who claims an invasion of privacy, should have the burden of establishing the elements of such a claim under applicable state law.

\section{CONCLUSION}

It is commonly noted that copyright scholars divide into two basic camps: the utilitarians and the moralists. ${ }^{310}$ Generally speaking, the utilitarians argue that the clief, perhaps only, legitimate role of statutory copyright is to maximize public access to expressive works. To that end, they advocate interpretations that promote "incentives" sufficient to induce maximum creation and minimize opportunities for rent-seeking or censorship. The moralists, on the other hand, add to the utilitarian goals the preservation of certain personal interests of the individual author, particnlarly the latter's interest in personal privacy and integrity of workproduct, otherwise known as informational and decisional privacy.

One may distinguish the utilitarians from the moralists in part by a basic difference in respective assessments of the appropriate legal

309. These suggestions are consonant with, but not identical to, Professor Crews' recommendations on shifting the burden of proof. Crews, supra note 15.

310. Paul Goldstein, I Copyright (2d ed. 1996) $\S \S 1.13-.13 .2 .3$ (describing historical antecedents of each perspcctive). 
protection due personal identity derived from labor and from property. Although that debate is ancient and continues to manifest itself in many arenas, the rhetoric is particularly knotty im copyright because the statutory subject matter, "original expression," is first the creator's labor and then his property. Although students of Locke and Marx, among others, will not find the conjunction surprising, ${ }^{311}$ the identity of labor with capital without an intervening medium of exchange, such as cash, seems relatively strange in a modern industrial economy. The rhetorical complexity of the fusion is heightened by the fact that the labor is "expressive," implicating personal identity, politics, markets (as in the cultural icon of "free speech") and the concomitant right not to speak. The negative right to remain silent alludes to the dark half of identity and privacy, and to freedom from coercive powver. Thus, woven into "copyright" are references to labor that produces capital, the capital itself, identity, particularly the ability to express oneself, and privacy, the ability to control access to information about oneself. So, as happens so often in legal practice, judicial opinions, and scholarship, we find ourselves arguing over humanism, work, identity, thought, and freedom, in the strange dialect of "copyright" and "fair use."

The utilitarians have weakened their argument by a stubborn insistence that the copyright statute simply does not apply to the moralists' concerns, such as privacy. ${ }^{32}$ They have resorted to deconstructing the Romantic notion of authorship, which is indeed a cultural construct, in an effort to minimize the appeal of authors' rights, such as privacy, integrity, and autonomy. ${ }^{313}$ This approach reminds me of the majority reasoning in Lochner v. New York, ${ }^{314}$ which we now think over-emphasized the Founders' devotion to freedom of contract. In this instance, the utilitarians place too much weight upon the Founders' alleged utilitarian intent for the Copyright Clause. ${ }^{315}$ No one denies that the Clause's wording evinces a utilitarian intent; but neither that, nor such legislative history as one may choose to find persuasive, proves that the Founders would have rejected authors' rights. In fact, the hearkening back to original intent simply begs the question of how to apply a concededly utilitarian Clause and modern, mainly utilitarian statute to hard cases where other serious interests are implicated. Even from a utilitarian perspective, a significant threat to creators' privacy will probably result in the destruction of many works and

311. For an intellectual history of intellectual property theory, see DRAHos, supra note 91.

312. See, e.g., Leval, supra note 38, at 1125-30 (arguing that good faith, artistic integrity, and privacy are "false factors that should not enter the fair use determination"); Patterson, supra note 38 at 48-52, 63-65. Cf. Weinreb, supra note 16 at 114 (criticizing Leval for an exclusively utilitarian analysis of fair use).

313. E.g., Woodmansee \& Jaszi, supra note 91.

314. 198 U.S. 45 (1905).

315. U.S. Const. art. I, $\S 8$ ("The Congress shall have Power... to Promote the Progress of Science and useful Arts, by securing for limited Times to Authors and Inventors the exclusive Right to their respective Writings and Discoveries.") (emphasis added). 
other useful, if less substantial, expression. At the same time, the courts should not undermine scholarly accuracy and public information and debate by cloaking inchoate claims of authors' rights or privacy for an expression with a blanket copyright for seventy years after the author's death. 


\section{ApPendix: Selections from Simon \& Schuster Contract}

36. Author is the sole author and proprietor of the Literary Work.

38. The Literary Work is wholly original, has not been previously published, and is not in the public domain.

39. The Literary Work does not infringe any statutory or common law copyright or any proprietary right of any third party.

40. The Literary Work does not invade the right of privacy of any third person, or contain any matter libelous or otherwise in contravention of the rights of any third person, and, if the Literary Work is not a work of fiction, all statements in the Literary Work asserted as facts are true or are based upon reasonable research for accuracy.

41. (a) The Literary Work contains no matter which is obscene or matter the publication or sale whereof otherwise violates any federal or state statute or regulation.

41. (c) If the Author incorporates in the Literary Work any writings, drawings, photographs or other material either previously published or not, either by the Author or another artist or writer, Author shall, prior to delivery of the Literary Work in final form obtain and, whenever requested by Publislier, deliver to the Publisher proper and complete written permission and authorization from the owner of the common law or statutory copyright or other right to use the same in the Literary Work and for the purpose of promoting or advertising the Literary Work throughout the territory of grant as set forth in Paragrapli 46 hereof.

43. The Publislier shall be under no obligation to make an independent investigation to determine whether the foregoing warranties and representations are true and correct; and any independent investigation by or for the Publisher, or its failure to investigate, slrall not constitute a defense to the Author in any action based upon a breacli of any of the foregoing warranties.

83. (a) Nothwithstanding anything contained herein to the contrary, the Publisher shall not be obligated to publish the Literary Work if, in its sole and absolute judginent, whether before or after acceptance thereof, the Literary Work contains libelous or obscene material, or its publication would violate the right of privacy, common law or statutory copyright, or any other right of any person. In sucli event, unless Author makes changes required by Publisher's legal counsel in sucli counsel's reasonable judgment, Publisher shall be entitled on demand to the return of all moines advanced to the Author liereunder, and to terminate this agreement. 
Notwithstanding any request by Publisher for change or substantiation, nothing in this agreement shall be deemed to impose upon the Publisher any duty of independent investigation or to relieve the Author of any of the obligations assumed by Author hereunder, mcluding, without limitation, the ongoing validity of Author's warranties and representations. No changes made by Author as the result of requests made by Publisher's legal counsel shall be deemed to affect or limit the Author's warranties or indemnity which shall apply to the changed material.

87. (a) The Author shall indemnify and hold the Publisher harmless against any loss, liability, damage, cost or expense (including reasonable attorneys' fees) arising out of or for the purpose of avoiding any suit, proceeding, claim or demand or the settlement thereof, which may be brought or made against the Publisher by reason of the publication, sale, or distribution of, or disposition of rights im respect to the Literary Work, based on the contents of the Literary Work (except for disputes about commercial transactions between Publisher and its customers).

87. (b) No suit, proceeding, claim or demand brought against the Publisher under which the Author is required to indemnify the Publisher may be settled without the Author's consent, such consent not to be unreasonably withheld. If within such time as the situation may allow, the Publisher shall request the Author to consent to the proposed settlement, and the Author shall neglect or decline to do so, the Author shall upon written notice by the Publisher immediately undertake to continue the defense at Author's sole expense and shall provide the Publisher with security in the form of a surety company bond in the amount as shall under all circumstances be in the Publisher's opinion adequate. In the event the Author fails to so assume the defense, and to furnish such bond, the Publisher shall have the right to settle such matter upon terms Publisher thinks advisable or in its discretion to continue the defense thereof, and the Author's indemnity shall be applicable in either such event, provided, however, that nothing herein continued shall inhibit the Publisher from settling any such claim, suit, action or proceeding against it at its own cost and expense. In the event any action or proceeding for libel or violation of right of privacy is settled for a total expense (including reasonable attorneys' fee [sic]) of $\$ 10,000$ or less or any action is finally judicially determined favorably to the Publisher, the Author's liability under this indemnity shall be limited to one-half the expense of the defense thereof. In addition, any expenses (including reasonable attorneys' fees) resulting from a suit, proceeding, claim or demand by a governmental agency including claims that the Literary Work is obscene or contains obscene material shall be shared equally between the Author and the Publisher, 
provided that Publisher shall have complete control over the conduct of the defense of any such governmental claim, action of proceeding.

89. If any suit, claim or demand is brought or made, other than as excepted in paragraph 87 , the Publisher may elect (i) to undertake the defense thereof in which event the Author shall have the right to retain his or her own counsel at his or her own expense, or (ii) to notify the Author to undertake the defense. If the Publisher does so notify the Author, the Author shall undertake such defense; and in such cases the Publisher may, at its option, join in the defense. In all the foregoing events the cost and expense of any defense shall be borne by the Author, unless (a) such suit, claim or demand arises solely out of an act or omission of the Publisher, in which case the cost and expenses shall be borne by the Publisher, or (b) the Author has, pursuant to notification from the Publisher, undertaken the defense and the Publisher at its option elects to join with the Author in the defense, in which case the total cost and expense (including reasonable attorneys' fees) shall be shared equally by the Publisher and Author.

90. Whenever any non-excepted suit, claim or demand is instituted, the Publisher may withhold payments due to the Author under this agreement, or any other agreement between the Author and the Publisher. If a final adverse judgment is rendered in such a suit and is not discharged by the Author, the Publisher may apply the payments so withheld to its expenses and to the satisfaction and discharge of such judgment. Notwithstanding anything herein to the contrary, if a claim or demand shall [not be prosecuted within a year, no withholding is allowed.] Author shall be insured under the Publisher's liability policy which covers claims for libel and other forms of defamation, invasion of privacy or publicity and infringement of copyright or trademark arising from publication of the Literary Work, to the extent such policy is valid and collectible. In connection with such coverage and notwithstanding the other provisions of this Part Nine, with respect to all judgments, settlements and costs of defense, including attorneys' fees and other costs or claims covered by the policy, the Publisher and the Author shall share equally the first $\$ 100,000$ of all such costs; thereafter the Author's liability shall be limited to $10 \%$ of all such costs up to the limits of the policy. Publisher shall retain counsel to represent Publisher and Author in any proceeding brought with respect to all such claims and shall control the defense of such claims, and Author shall cooperate fully with Publisher and said counsel im such defense. Notwithstanding the foregoing, Author shall be solely responsible for the cost of counsel separately retained by the Author for any reason and for judgments, settlements and costs of defense, including all attorneys' fees, 
attributable to a willful or reckless breach of this agreement by Author, and for any uninsured amount upon the finding of any copyright infringement. 